Center for International Forestry Research (CIFOR)

Bogor, Indonesia

AFRICA'S TROPICAL DRY FORESTS - TIME TO RE-ENGAGE AN AGENDA FOR PRIORITY RESEARCH

June 2002

This work has been made possible through funds made available to CIFOR by the Swedish International Development Co-operation Agency (Sida) 



\section{Acknowledgements and authorship}

This report is based largely on a manuscript of the same title assembled from commissioned reviews for CIFOR by Gill Shepherd, Overseas Development Institute. Mafa Chipeta and Bruce Campbell provided review and have compiled sections 2 and 3. Funding for this activity, from the Swedish International Development Cooperation Agency (Sida), is gratefully acknowledged. 
Acronyms

\begin{tabular}{|c|c|}
\hline AFORNET & African Forestry Research Network \\
\hline CAMPFIRE & Communal areas Management Programme for Indigenous resources \\
\hline CBNRM & Community-Based Natural Resource Management \\
\hline CIDA & Canadian International Development Agency \\
\hline CIFOR & Center for International Forestry Research \\
\hline CIRAD & $\begin{array}{l}\text { Centre de Coopération Internationale en Recherche Agronomique pour } \\
\text { le Développement - France }\end{array}$ \\
\hline $\begin{array}{l}\text { CILSS } \\
\text { CORAF-Forêt }\end{array}$ & $\begin{array}{l}\text { Comité Permanent Inter-Etats de Lutte contre la Sécheresse au Sahel } \\
\text { Conseil Ouest et Centre Africain pour la Recherche et le Développement } \\
\text { Agricoles }\end{array}$ \\
\hline DFID & Department for International Development, UK \\
\hline DFID FRP & DFID Forestry Research Programme \\
\hline DANIDA & Danish International Development Agency \\
\hline EC & European Community \\
\hline FINNIDA & Finnish International Development Agency \\
\hline FAO & Food and Agriculture Organisation \\
\hline FORNESSA & Forestry Research Network in Sub-Saharan Africa \\
\hline GTZ & German Agency for Technical Cooperation \\
\hline IARC & International Agricultural Research Center \\
\hline ICRAF & International Centre for Research in Agroforestry \\
\hline ICRISAT & International Center for research in the Semi-Arid Tropics \\
\hline IDRC & International Development Research Center \\
\hline IFF & International Forum on Forests \\
\hline IMF & International Monetary Fund \\
\hline INSAH & Institut du Sahel \\
\hline IPF & International Panel on Forests \\
\hline IUCN & World Conservation Union \\
\hline IUFRO & International Union of Forestry Research Organisations \\
\hline JFM & Joint Forest Management \\
\hline LFCC & Low Forest Cover Countries \\
\hline NEAP & National Environmental Action Plan \\
\hline $\mathrm{NAP} / C D$ & National Action Programmes to Combat Desertification \\
\hline NGO & Non-Governmental Organisation \\
\hline NORAD & Norwegian Agency for Development \\
\hline NR & Natural resources \\
\hline NRM & Natural resource Management \\
\hline NTFP & Non-timber forest product \\
\hline NWFP & Non-wood forest product \\
\hline ODI & Overseas Development Institute \\
\hline RIOD & Réseau International des ONG pour la lutte contre la Désertification \\
\hline
\end{tabular}


ROPPA Réseau des Organisations Paysannes et des Producteurs Agricoles de l'Afrique de l'Ouest

SADC Southern African Development Conference

SIDA Swedish International Development Agency

SNRAA Système National de Recherches Agricoles et Agro-alimentaires

UNCCD United Nations Convention for the Control of Desertification

UNCED UN Conference for Environment and Development

UNESCO UNEconomic, Social and Cultural Organisation

UNFF UN Forum on Forests 


\section{TABLE OF CONTENTS}

Acknowledgements and authorship ..........................................................................

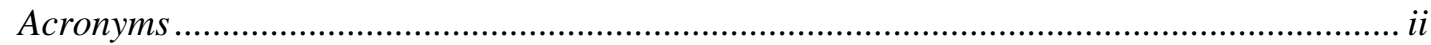

Overview and summary ...................................................................................................................... 1

Process of arriving at a research agenda .............................................................. 1

Reviewing the key issues and questions in dry forests .................................................. 1

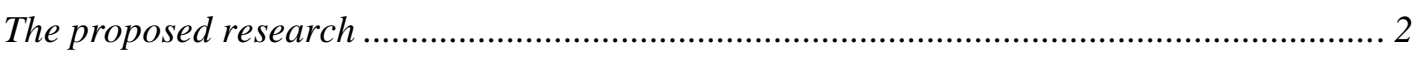

SECTION 1. Issues and questions in dry forest research and development .................. 5

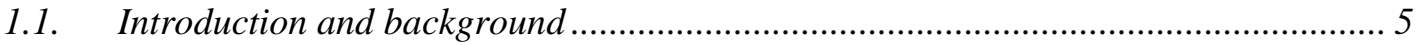

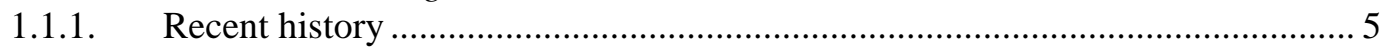

1.1.2. The significance of dry forests and arguments favouring re-engagement ........... 7

1.2. Dry forests in Francophone West Africa …............................................................. 9

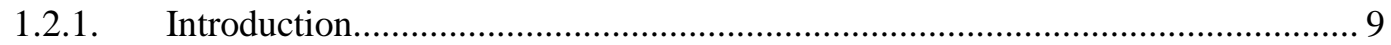

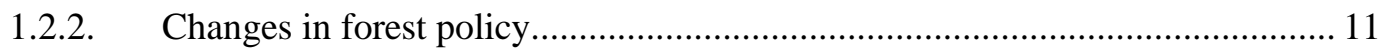

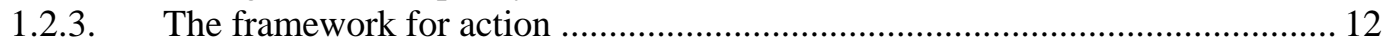

1.2.4. Some achievements in forest management in Sahelian Francophone West

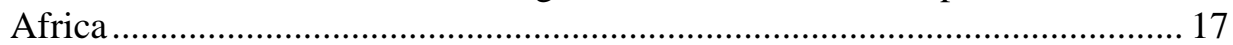

1.2.5. Factors limiting the effective management of natural forest ........................... 17

1.2.6. Suggested priority studies for dry forest development .................................... 17

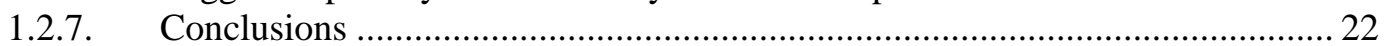

1.3. Dryland Anglophone Africa North of the Equator-Sudan, Kenya, N. Ghana, N

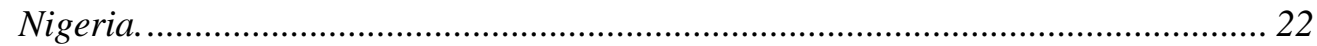

1.3.1. Nature and condition of the dry forests ......................................................... 22

1.3.2. A review of experience with the management of dry forests/woodlands .......... 23

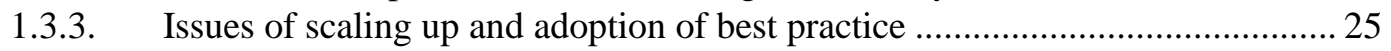

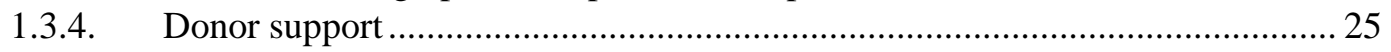

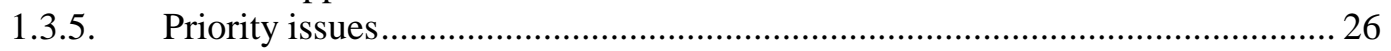

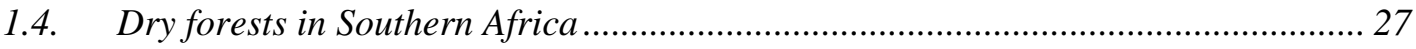

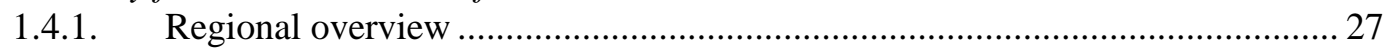

1.4.2. Review of experiences with the management of dry forests/woodlands ........... 28

1.4.3. Apparent causes of SFM failures to upscale or get adopted................................32

1.4.4. Issues needing more attention in research ............................................................ 34

1.4.5. Key socio-economic issues in the dry forests of Southern Africa ...................... 34

1.5. Conclusions, comparative issues and recommendations ......................................... 35

1.5.1. How do we measure and monitor the role of forests in the livelihoods of the poor and how do we aggregate to national level? ....................................................... 35

1.5.2. 'The art of the possible': cost-effective, appropriate, sustainable forest

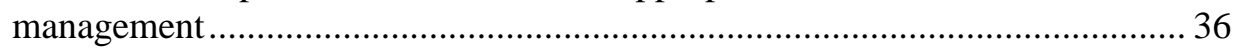

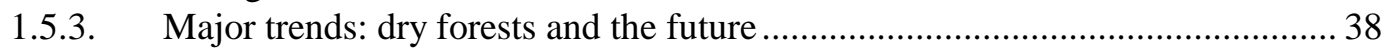

1.5.4. Dry Forests and Climate Change: a dry run on how adaptation takes place in a

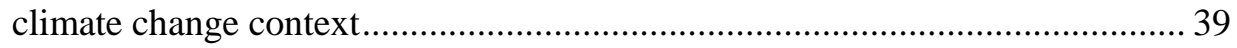

1.5.5. Collaborative forest management north and south of the equator ..................... 40 


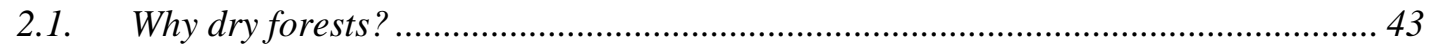

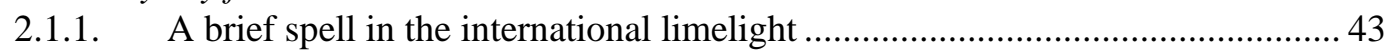

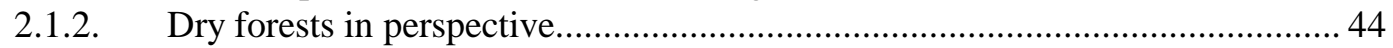

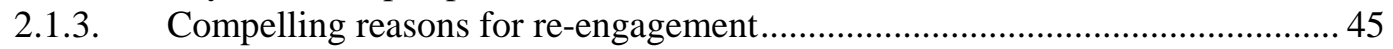

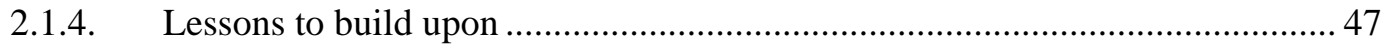

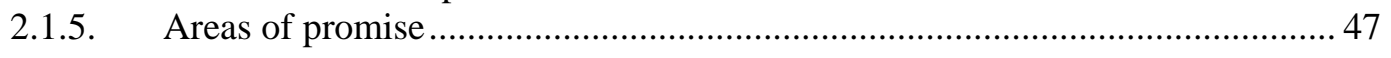

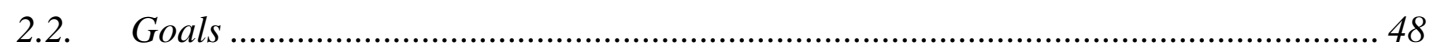

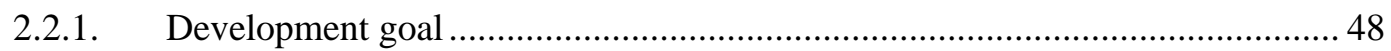

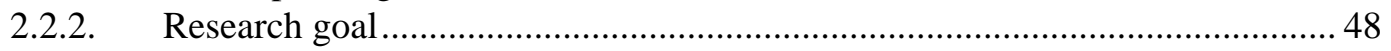

2.3. What research is proposed - the five focus topics ................................................... 49

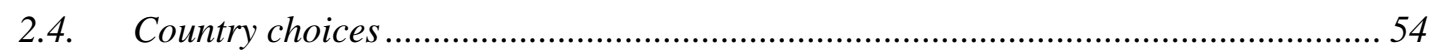

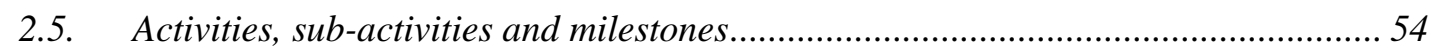

2.6. Institutional arrangements for project implementation ...........................................5 55

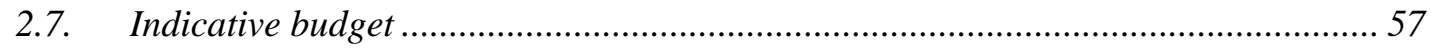

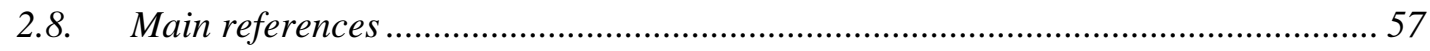

SECTION 3. Stimulating policy dialogue on sustainable management of Africa's dry forests - Proposal to Sida for a Dry Forest Programme ........................... 59

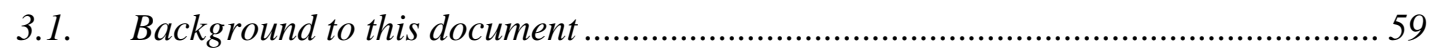

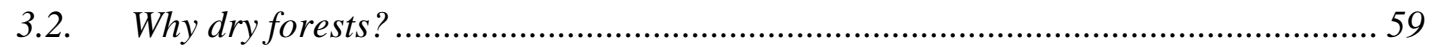

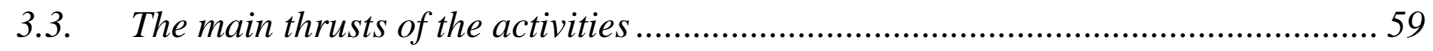

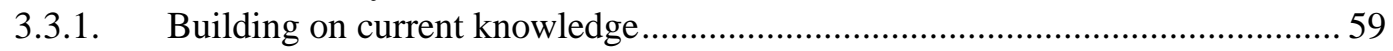

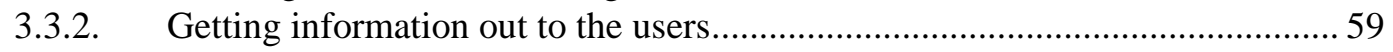

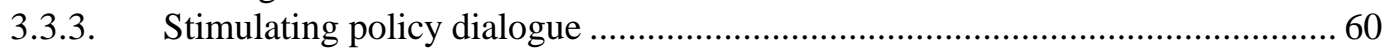

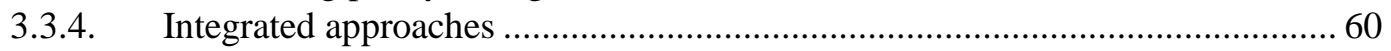

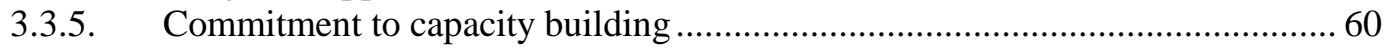

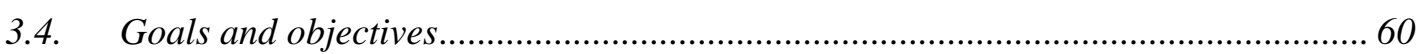

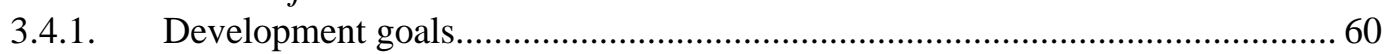

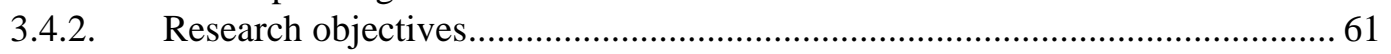

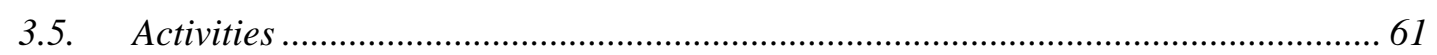

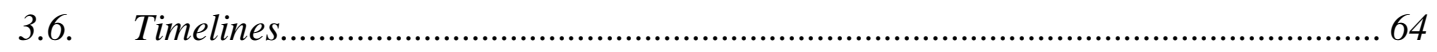

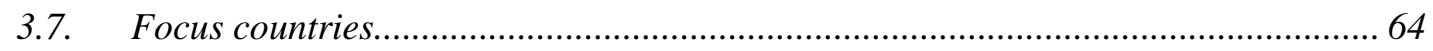

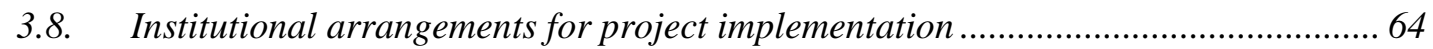

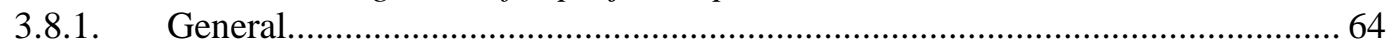

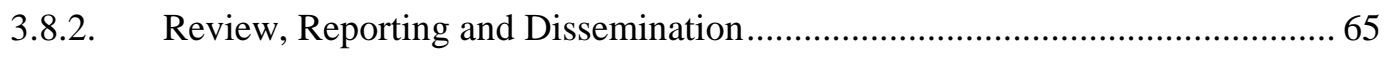

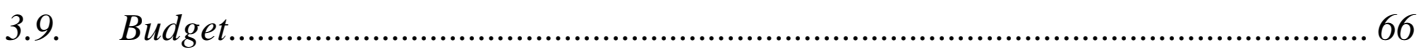

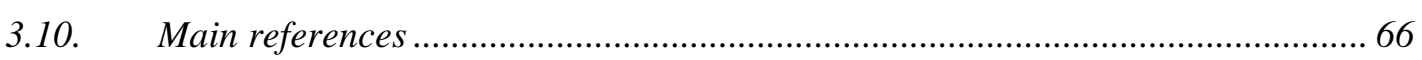


Annexes.

Annex 1.1: Key African countries containing tropical dry forests : basic data and some

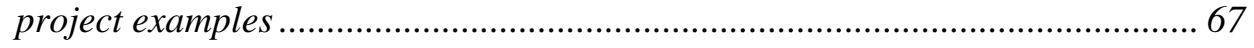

Annex 2.1: Framework of potential activities AND milestones in four focus areas ............ 97

Annex 2.2: Dry sub-regions' extract from Africa research prioritisation meeting............. 109

Annex 2.3: Africa - selected forest resource and conservation indicators......................... 113

Annex 3.1: Stakeholder groups that will be engaged in the dry forest Programme ........... 115 


\section{OVERVIEW AND SUMMARY}

This document reviews the state of research in African dry forests and sets up the framework for a dry forest programme of research in the Center for International Forestry Research (CIFOR). The document consists of three sections, which represent increasing levels of focus in a proposed dry forest research programme.

- Section 1 ("Issues and questions") largely consists of the review of the main issues in dry forests, and suggests various lines of research. It presents issues in the context of three regions: Francophone West Africa; Anglophone Africa north of the equator; and Southern Africa.

- Section 2 ("A Framework for a Dry Forests' Programme") provides the justification, framework and over-arching objectives for CIFOR's research and development agenda on dry forests, and was prepared after further internal discussion amongst CIFOR staff.

- Section 3 ("Summary Proposal to Sida for a Dry Forest Programme") is the proposed research agenda, given the immediate funds that are available.

\section{Process of arriving at a research agenda}

The identification of research priorities is no easy matter for a continent of Africa's diversity. Each sub-region and each country has singular attributes that make choice of overall priorities difficult. The process of priority selection has been informed by four main processes: (a) previous exercises to prioritise research in miombo woodlands (Dewees, 1994; Campbell 1996), (b) views from the March 2000 meeting of the CIFOR Board of Trustees in Harare, Zimbabwe, based on the paper by Mafa Chipeta "Towards a strategy for sub-Saharan activities of the Center for International Forestry Research (CIFOR)"; (c) a CIFOR-convened meeting in Yaounde, Cameroon, in February 2001, attended by a wide range of stakeholders, to select priority research topics for Africa, including those for dry forests, as reflected in the document "Forestry research in Sub-Saharan Africa: Review of priorities" (CIFOR, 2001) and (d) the mid-2001 review by Gill Shepherd leading to the current Section 1.

\section{Reviewing the key issues and questions in dry forests}

Dry forests constitute one of the major terrestrial ecosystems, existing in all developing regions of the world: Africa, Asia, and Latin America. Proportionately, they are most prominent in Africa, where drier forests in all their varieties - from the desert margin scrub to closed woodlands to deciduous forests - support the most people and livestock of all the continent's ecosystems. Dry forests arrived at centre 
stage of international co-operation during the "Sahelian" drought of the late 1970's to early 1980's and during "the other energy crisis", but enthusiasm for forestry projects and dryland projects has waned. There are now compelling reasons for reengagement in and additional attention to dry forests, including, amongst many reasons, the rise in HIV/AIDS and the likelihood of negative climatic trends. The time has come to reflect: Did everything in the Sahelian efforts really fail? Were the technologies that were attempted all bad? Were the social organisational efforts, which for the first time introduced people's participation on a significant scale, all inadequate or improperly executed? What are the pathways to poverty alleviation in dry forest regions? The CIFOR programme in dry forests needs to reflect on the past experiences, answer such questions and chart a way forward. CIFOR and partners are in a unique position to make significant impacts on the development trajectories in dry forests.

\section{The proposed research}

Section 2 ("A Framework for a Dry Forests' Programme") provides the justification, framework and over-arching objectives for CIFOR's research and development on dry forests, with a focus on Africa. It sets the broad agenda to which CIFOR will aspire through seeking funds from a variety of donors. Section 3 is the specific proposal to Sida for funds.

The overall development goalsuggested in the Framework is to enhance the social and economic development of Africa. Africa, as the poorest continent, has the greatest dependence on natural resources of any continent, and its forests play a more important livelihood role than in any other continent. The overall research goal is to strengthen the scientific and other analytical base necessary so that dry forests can play an effective and sustainable part in contributing to economic and social development.

The goals will be met through five specific areas of focus. In each of the focus areas a number of possible activities have been identified in the Framework; this represents a basket of possibilities to select from as the adaptive dry forest programme emerges. The five focus areas are as follows:

- Understanding contributions of dry forests to local livelihoods and national economies and determining pathways to poverty alleviation (Topic 1).

- "The art of the possible" - tailoring sustainable management approaches for dry forests to the social, economic and technological capacities in Africa (Topic 2).

- Major trends - understanding key extra-sectoral determinants relevant to crafting policies and sustainable - management approaches for dry forests (Topic 3).

- Anticipating climate change - the Sahelian drought as Africa's "dry run" on 
socio-ecological resilience and adaptation in the dry forest zone (Topic 4). - Collaborative forest management north and south of the equator (Topic 5).

The proposed research will be multi-faceted and interdisciplinary. It will look at biophysical, socio-cultural, policy, and institutional factors that determine sustainable dry forest management.

It is proposed that research effort be concentrated on a few countries, although case studies on specific themes can cover other countries outside the focus list.

We envisage promoting change through policy dialogue. All research Topics would have a policy component, with the intention of understanding the nature of gaps in the policy dialogue continuum, how to bridge them, and how to best inform policy formulation, once we have the research data with which to promote change.

There are numerous stakeholders involved in research and development in dry forest systems, and many involved in the management of dry forests. If this programme is to have the desired impact, then CIFOR will need to form appropriate collaborative mechanisms with the various partners.

We envisage a programme in the order of US $\$ 1.5$ million - US $\$ 2.0$ million over a 4year period (2002-2005). CIFOR will serve as implementing agency and will manage the funds, including responsibility for reporting on technical and financial matters.

This framework proposal provides some of the summarised background documents used in the preparation of a dry forest strategy: African research prioritisation results (Annex 2.1); key issues in dry forest management (Annex 2.2); and selected country indicators (Annex 2.3). 


\section{SECTION 1. ISSUES AND QUESTIONS IN DRY FOREST RESEARCH AND DEVELOPMENT}

\subsection{Introduction and background}

Dry forests and woodlands are a major type of ecosystem, existing in all developing regions of Asia, Africa and Latin America. Proportionately, they are most prominent in Africa. On that continent, it is the drier forests, from the Acacia-Commiphora Sahelian woodlands bordering desert margins to open woodlands bordering more humid ecosystems that support the most people and livestock of all the continent's ecosystems.

\section{Box 1.1: A note on the definition of "dry forest"}

Baseline data regarding the current status of dry forests in the region has mainly been obtained from the FAO Forest Resource Assessment 2000. This assessment uses the following definitions:

Tropical Dry Forest

Climatic Criteria: $\quad$ Tropical climate, with summer rains and a dry period of 5-8 months. Annual rainfall ranges from 500 to $1500 \mathrm{~mm}$.

Vegetation: $\quad$ Dry tropical forest and woodland, including drier type of Miombo and Sudanian Woodlands, savanna (Africa).

Distribution: At both sides of the equator, approximately between 15 and 20 degrees. This zone is the most extensive in Africa

Tropical Shrubland

Climatic Criteria: $\quad$ Tropical temperature regime and evaporation > precipitation. Annual rainfall ranges between 200 and $500 \mathrm{~mm}$.

Vegetation: $\quad$ Shrubs, xeromorphic woodlands, dry savanna, thornbush

Distribution: $\quad$ Most extensive in Africa and South Asia, where they form the equator-ward margins of the tropical deserts

\subsubsection{Recent history}

Dry forests arrived at centre stage of international co-operation efforts during the Sahelian drought of the late 1970s to early 1980s when an abnormal succession of particularly dry years in West Africa led to loss of much livestock, decimation of rangelands and woodlands, and a crisis in the supply of woodland products. The drought coincided with heightened concern over shortage of fuelwood after the oil 
price-hikes of the 1970s. The combination attracted almost all donors to initiate major fuelwood planting programmes; programmes that provided the first major proving ground for participatory forestry. Over time, it came to be realised that protecting natural regeneration would create significantly greater resources than plantations and much more cheaply, so gradually a perception of the validity of existing practices of local people in forest protection and management came into existence, as a result of the initial engagement with them for fuelwood planting projects.

By the mid-1980s, the enthusiasm for technical assistance and investment in dry zone forestry was waning, and by the late 1980 s only a few donors persisted in supporting fuelwood or any other forestry projects in the Sahel and other dry woodlands; among the donors persisting were the Nordic countries, the Netherlands and the World Bank. So dismal were the yields and so high the failure rates of many planted woodlots and related initiatives in the Sahel, that donor enthusiasm for similar initiatives elsewhere in the world was dampened.

In the years that followed, two further factors may have reinforced the weakening of attention to dry forests: firstly, the post-Earth Summit era witnessed the diversion of almost all donor funding to the humid tropical forests due to perceived urgency of protecting their threatened rich biodiversity; secondly the end of the Cold War, which removed strategic interest from north-east African countries (such as the Sudan and Somalia) that had bordered revolutionary Ethiopia, and from countries in the West African Sahel lying adjacent to uranium-rich Niger. So the promising initiatives with local people and natural regeneration were largely abandoned, except by a small handful of NGOs.

Innovative techniques promoted by donors or being tried by local people were also abandoned or ceased to attract external notice. These included, for instance, the management of natural woodlands for fuelwood linked to community-controlled fuelwood markets; the popularisation of participatory approaches to resource management and site-preparation techniques that slowed down water-loss rates and reduced mortality.

There have been other key changes in the period, which justify rekindling of interest in dry forests. Most significant perhaps is that many countries have redrafted their forest policies over the last decade, to include in many cases more devolution of forest management to local people - alone or in collaborative arrangements with government. This handover has taken place much faster and much more readily in countries where the commercial, including export, timber value of the forests is low in dry forests, that is to say. Secondly, many other non-forest policies have come into existence, and have major implications for the management of forests - such as those concerning poverty reduction and good governance. Thirdly, forests have had a considerable degree of attention since Rio, through the processes of IPF, IFF and 
now UNFF - in their later stages, these processes have drawn increased attention to countries "with low forest cover". Finally, Africa, in particular, has been experiencing the fastest rates of population growth and urbanisation in the world, the spread of HIV/AIDS etc., factors which variously make for very dynamic people-resource changes in many of Africa's dry forest areas. These deserve to be understood better.

\subsubsection{The significance of dry forests and arguments favouring re- engagement}

In terms of direct relevance to livelihoods, dry forests are particularly important. Table 1.1 shows the comparative numbers of people supported by different types of forest and the rates of forest loss occurring.

Table 1.1: Tropical forest type distribution in relation to population and deforestation - 1990.

\begin{tabular}{|c|c|c|c|c|c|c|c|c|c|c|}
\hline \multirow{2}{*}{\multicolumn{2}{|c|}{ Ecological zone }} & \multicolumn{2}{|c|}{$\begin{array}{l}\text { Area covered } \\
\text { by Eco-zone }\end{array}$} & \multirow{2}{*}{$\begin{array}{c}\begin{array}{c}\text { Population } \\
\text { density }\end{array} \\
\text { (persons/ } \\
\text { sq. km) }\end{array}$} & \multicolumn{2}{|c|}{$\begin{array}{c}\text { Total } \\
\text { population }\end{array}$} & \multicolumn{2}{|c|}{$\begin{array}{c}\text { Forest \& } \\
\text { woodland area }\end{array}$} & \multicolumn{2}{|c|}{ Deforestation } \\
\hline & & $\begin{array}{l}\text { (mill. } \\
\text { ha) }\end{array}$ & $\%$ & & (mill.) & $\%$ & $\begin{array}{l}\text { (mill. } \\
\text { ha) }\end{array}$ & $\%$ & $\begin{array}{c}\text { (mill. } \\
\text { ha) }\end{array}$ & $\%$ \\
\hline \multicolumn{2}{|c|}{ Rainforest } & 947 & 19.8 & 41 & 388 & 15.6 & 718 & 76 & 4.6 & 0.6 \\
\hline \multirow[t]{3}{*}{$\begin{array}{l}\text { Dry } \\
\text { forest }\end{array}$} & $\begin{array}{c}\text { Moist } \\
\text { deciduous }\end{array}$ & 1289 & 27.0 & 55 & 709 & 28.5 & 587 & 46 & 6.1 & 0.9 \\
\hline & $\begin{array}{c}\text { Dry } \\
\text { deciduous }\end{array}$ & 706 & 14.8 & 106 & 748 & 30.1 & 179 & 25 & 1.8 & 0.9 \\
\hline & $\begin{array}{l}\text { Very dry } \\
\text { scrub }\end{array}$ & 543 & 11.4 & 24 & 130 & 5.2 & 60 & 11 & 0.3 & 0.5 \\
\hline \multicolumn{2}{|c|}{ Mountain forest } & 701 & 14.7 & 56 & 393 & 15.8 & 204 & 29 & 2.5 & 1.1 \\
\hline \multicolumn{2}{|c|}{ Other } & 592 & 12.4 & 15 & 89 & 3.6 & 8 & 1 & 0.1 & 0.9 \\
\hline \multicolumn{2}{|c|}{ Total } & 4778 & 100 & 52 & 2485 & 100 & 1756 & 37 & 15.4 & 0.8 \\
\hline
\end{tabular}

Source: Based on FAO (Mainly Forest Resources Assessment 1990). Unfortunately the recent FAO forestry assessment does not provide sufficiently detailed breakdown of deforestation by ecological type so we have used the older data. 'Dry forest' in our usage is covered by moist deciduous forest (e.g. miombo woodland), dry deciduous forest (e.g. Acaciaspp, Colophospermum mopane, Adansonia) and very dry scrub (e.g. shrublands of Acacia and Commiphora).

Table 1.1 shows that lands in the rainforest zones (which have attracted virtually all the forestry donor attention in the last decade) have about $20 \%$ of the land area in the tropics and support about $15 \%$ of the population. By contrast, the deciduous (i.e. drier) forest ecosystem areas occupy about $54 \%$ of the land area and contain about $64 \%$ of the population; the dry deciduous forestbelt alone supports about a third of the population on only a sixth of the area. Some populous countries are either dominated by or have extensive areas of dry forests, including India, Pakistan, and Nigeria. Furthermore, the last two columns of Table 1.1 show that together, a total of 8.2 million ha of deciduous forests are lost annually compared to 4.6 million ha of humid ecosystems. 
The average deforestation rate in both moist and dry deciduous forests is, at $0.9 \%$ annually, some $50 \%$ higher than in rainforests. ${ }^{1}$ It is clear that, proportionately, the drier forest ecosystems face far higher human and other development pressure that the moist forests. Livestock populations are also high and consequently competition for habitat with wildlife is considerable and growing.

Dry forests, far more than the rainforest, are central to food security. It is the dry woodlands that offer most of the potential agricultural expansion frontier. These threatened dry woodlands offer protection for the water and soil resource base for agriculture. They offer the bulk of dry-season fodder for vast livestock populations, without which this sub-sector would in most cases be unviable. They provide fuelwood for domestic and rural industry-uses, including for drying major agricultural crops and fish. They offer construction material for farm structures and homes for millions. They also have visible but often unacknowledged support roles for agricultural production - some of which have been mentioned here.

They are home to precious woods, such as African ebony, valued in handicraft industries or for quality musical instruments. They provide raw materials for packaging and wares used in homes and in harvesting farm produce. They are the source of important non-timber forest products such as shea butter; and are the home of much biodiversity of daily use for medicines and for cross-interaction with agricultural systems. The drier woodlands may not yield much high quality timber, but their other life-support roles have vast importance and are also being exposed to the greatest pressures. Furthermore, at a time when alternative economic opportunities remain under-developed, case studies have shown up to a third of rural incomes to come from woodlands in parts of dry Africa.

\section{Box 1.2: Countries with low forest cover ${ }^{2}$}

From post-Earth Summit dialogue on forests has come a new term, LFCC - low forest cover countries - defined to include those with $10 \%$ or less tree cover. According to a FAO document prepared for the October 1999 Tehran meeting on this topic, 5 countries in the Asia-Pacific, 20 countries (of 43) in sub-Saharan Africa, 20 (i.e. nearly all) in the Near-East and North Africa fall into this category. Furthermore, although China averages $14.3 \%$ forest cover, the average hides its major expanses lacking forest vegetation, and the fact that it's per caput forest area is only 0.1 ha. Altogether, some 70 developing countries have been classified under the low forest cover category, with the population affected totalling some 300 million to 400 million.

\footnotetext{
${ }^{1}$ Rates of deforestation are notoriously unreliable, so little confidence can be placed on the actual numbers. ${ }^{2}$ Sources: Proceedings: the International Meeting on Special Needs and Requirements of Developing Countries with Low Forest Cover, and Unique Types of Forests. Tehran, Iran October 4-8, 1999. Forest and Range Organisation, Tehran, Iran. Especially Ball, "Overview of Low Forest Cover Countries in Developing Regions"; and "Report of the Open-ended Meeting of Experts".
} 
A decade has now passed since slowdown of donor activity on dry forests. The countries where dry forests are mainly to be found - especially those in Africa north of the Sahara - have received only modest attention in that period. This has been only partly due to disenchantment with earlier efforts; dry forest engagement has also suffered from political upheavals in many areas. In any case, many promising lessons which were beginning to be learned have largely been abandoned. In summary, dry forests deserve renewed attention because:

- They support far larger populations than humid forests;

- Rural areas, and remote rural areas in particular, where forests are more likely to be found, are where the poorest people are to be found;

- They are central to food security. They support more agriculture and are at the frontier of more agricultural expansion than humid forests. In particular, they are a direct source of food for livestock, a key component of dry zone agriculture;

- In some sub-regions, they are also the home of the wildlife reserves which are such important foreign exchange earning ventures from Kenya to South Africa. In the former country, tourism leads in national foreign exchange receipts; in Zimbabwe, woodland-oriented tourism is a major attraction for tourists - the same can be said for a number of other countries.

- Dry forest biological diversity has a relatively high incidence of usefulness for people to meet diverse agricultural, medicinal and other needs.

These and many other reasons explain a growing mood in favour of re-engagement with dry forest issues. The issues have been particularly highlighted in recent years through dialogue under the auspices of the UN Convention to Combat Desertification and the post-UNCED UN initiative on countries with low forest cover.

\subsection{Dry forests in Francophone West Africa}

\subsubsection{Introduction}

Living conditions will probably always remain difficult in dry rural Sahelian Africa. Population growth has intensified difficulties, but inward-migration into this narrow belt is probably equally important. Pastoralists who used to spend much of their year north of this belt are being forced south both by increasing desiccation ${ }^{3}$ and by the loss to incoming agriculturalists, if they abandon them for several months each year, of their 'fall-back' dry-season grazing areas further south. The loss of this niche may render valuable grazing resources further north all but unusable. At the same time, in their search for farmland, denser populations in higher rainfall areas to the south are edging further and further north into the Sahelian belt.

\footnotetext{
${ }^{3}$ What some consider to be the southward spread or creep of the Sahara desert.
} 
As a result, Sahelian forests are under heavy pressure. The exploitation of timber and non-timber forest products takes place alongside clearing for farming and overuse of pastureland. Forest formations are seriously threatened, and biodiversity is decreasing. Future supplies to meet growing needs are thus seriously compromised.

\begin{tabular}{|c|c|c|c|}
\hline \multicolumn{4}{|c|}{ Africa: tropical dry forest characteristics north of the Equator } \\
\hline Characteristics & $\begin{array}{c}\text { Sahel Zone } \\
\text { (Glantz) } \\
\text { Sahelo-Saharan } \\
\text { Zone (Bonkoungou) }\end{array}$ & $\begin{array}{c}\text { Sudano-Sahelian Zone } \\
\text { (Glantz) } \\
\text { Sahelian Zone } \\
\text { (Bonkoungou) }\end{array}$ & $\begin{array}{c}\text { Sudan Zone } \\
\text { (Glantz) } \\
\text { Sudan Savannah Zone } \\
\text { (Bonkoungou) }\end{array}$ \\
\hline Annual Rainfall & $200-400 \mathrm{~mm}$ & $400-600 \mathrm{~mm}$ & $\begin{array}{l}\text { Sudan } 600-800 \mathrm{~mm} \\
\text { (Sudan savannah to } \\
1,140 \mathrm{~mm} \text { ) }\end{array}$ \\
\hline $\begin{array}{l}\text { Mean Annual } \\
\text { Increment }\end{array}$ & $<0.3 \mathrm{~m}^{3} / \mathrm{ha}$ & $\begin{array}{l}0.06-0.5 \mathrm{~m}^{3} / \mathrm{ha} \text { with a } \\
\text { median of } 0.3 \mathrm{~m}^{3} / \text { ha at } \\
500 \mathrm{~mm} \text { rainfall }\end{array}$ & $\begin{array}{l}0.12-0.90 \mathrm{~m}^{3} / \mathrm{ha} \text { with a } \\
\text { median of } 0.6 \mathrm{~m}^{3} / \mathrm{ha} \text { at } \\
700 \mathrm{~mm} \text { rainfall }\end{array}$ \\
\hline $\begin{array}{l}\text { General } \\
\text { description }\end{array}$ & $\begin{array}{l}\text { Steppe, thorny semi- } \\
\text { desert scrub }\end{array}$ & $\begin{array}{l}\text { Shrub savannah to } \\
\text { steppe. True shrub } \\
\text { savannah has less than } \\
40 \text { trees per ha, } \\
\text { heights are under } 7 \mathrm{~m} \\
\text { and diameters only } 7 \text { - } \\
10 \mathrm{~cm}\end{array}$ & $\begin{array}{l}\text { Tree to shrub savannah. } \\
\text { True tree savannah has } \\
\text { over } 40 \text { trees per ha, } \\
\text { heights of over } 7 \mathrm{~m} \text {. and } \\
\text { over }\end{array}$ \\
\hline $\begin{array}{l}\text { Typical tree } \\
\text { species }\end{array}$ & $\begin{array}{l}\text { Acacia tortilis, A } \\
\text { senegal, A seyal }\end{array}$ & $\begin{array}{l}\text { Acacia seyal, } A \text {. } \\
\text { senegal, Balanites } \\
\text { aegyptiaca, Boscia. } \\
\text { spp., non-thorny } \\
\text { Combretaceae, } \\
\text { Faidherbia albida, } \\
\text { Guiera senegal-ensis, } \\
\text { Sclerocarya birrea }\end{array}$ & $\begin{array}{l}\text { Faidherbia albida, } \\
\text { Bombax costatum, } \\
\text { Sterculia setigera, } \\
\text { Anogeissus schimperi, } \\
\text { Prosopis africana, } \\
\text { Terminalia laxiflora. Also } \\
\text { much Butyrospermum } \\
\text { parkii, Parkia spp., } \\
\text { Tamarindus indica. }\end{array}$ \\
\hline Standing vol/ha & $0-5-6 \mathrm{~m}^{3} / \mathrm{ha}$ & $3-10-12 \mathrm{~m}^{3} / \mathrm{ha}$ & $5-18-20 \mathrm{~m}^{3} / \mathrm{ha}$ \\
\hline $\begin{array}{l}\text { Typical human } \\
\text { activities }\end{array}$ & $\begin{array}{l}\text { Agriculture near } \\
\text { water, animal rearing } \\
\text { predominant, } \\
\text { nomadic or } \\
\text { transhuman. Forage } \\
\text { production takes } \\
\text { precedence over } \\
\text { wood production. }\end{array}$ & $\begin{array}{l}\text { Agricultural } \\
\text { development, with } \\
\text { animal rearing } \\
\text { dominant, mainly } \\
\text { transhuman; wood or } \\
\text { forage may take } \\
\text { precedence, depending } \\
\text { on conditions. }\end{array}$ & $\begin{array}{l}\text { Intensive agriculture } \\
\text { (millet, sorghum } \\
\text { groundnut, part } \\
\text { transhuman and part } \\
\text { sedentary animal rearing. } \\
\text { Wood more important } \\
\text { than forage production. }\end{array}$ \\
\hline
\end{tabular}

Source: G Shepherd, FAO 1993 p183 


\subsubsection{Changes in forest policy}

National forest management policies in this region have seen several major shifts, in line with changing international policies and their impact on national priorities.

Before many countries attained political independence, their forest administrations were primarily concerned with the conservation and protection of forest lands for timber harvesting. A fixed rotation system was followed, with the forest divided up into coupes. After 1960, windbreaks were established, shade-trees planted along main roads, and forested areas protected. During this period, with relatively favourable climatic conditions and well-controlled forest management, rules were fairly widely respected. From the 1970s onwards, in the face of severe drought, national administrations began to attempt large-scale and usually very labour or capital-intensive re-afforestation. The attempts were State-run, and had limited success. These are now regarded as the area's First Generation projects.

In the early 1980s new approaches were tried, with more attempt to engage with local people (or at least with their unpaid labour). This is the era of "village woodlots", community plantations, community windbreaks, and the planting of trees in blocks and field boundaries on farm. The trees planted were intended to solve several problems at once by providing fuelwood, construction timber, shade, wind-protection, fodder and improved soil fertility. The Forest Development Plans drawn up at this time were innovative for the Sahel. The guidelines aimed at medium- and long-term strategies (by the year 2015), and sought, amongst other things to rehabilitate degraded ecosystems; develop exportable forest products; maintain forest potential; satisfy the needs of local populations for timber and non-timber products; improve rural living conditions and integrate trees into farming activities. An analysis of the experience of these Second-Generation projects shows that they were still overly sectoral, and that local populations were not adequately consulted about the nature of their engagement in proposed activities. Next, a new strategy, based on managing village lands (terroirs villagoises), was drawn up, leading to Third Generation francophone projects using the notion of forestry for local people.

Finally, the Fourth generation projects came into existence. They were able at last to give local populations more autonomy, allowing them to manage forest resources in the context of farming and livestock activities. Projects were designed and managed much more by the people themselves, forestry technicians working with them in advice and support roles.

It was in this last context that new forestry policies began to be drawn up, based on the principle of Forestry Action Plans. From about 1995, almost all the countries referred to in this section introduced two environmental planning activities: National Environmental Action Plans (NEAPs) and National Action Programmes to Combat Desertification (NAP/CD). The latter were designed as an integral part and major 
component of the NEAP, since desertification and the degradation of natural resources are, in many areas of the Sahel, the most acute environmental problem.

\subsubsection{The framework for action}

\section{The physical givens}

The climate of the Sahel is highly variable in both time and space, the vegetation growth period is short and biomass production potentially limited. The dry forests of the arid areas of West Africa grow on poor soils, and consist of open woodlands, savannas, steppe and bush. A distinction can be made between relatively dense forests and open woodlands, separated by strips of savanna (Sudan tropophile forests, characterised by Vitellaria paradoxa, Daniellia oliveri, Detarium senegalense, Parkia biglobosa, etc) and the drier zones covered by populations of thorny Acacias. The pattern is broadly shared by all the countries of the sub-region.

Despite frequent drought in the last two decades, these tropical forests have played a vital role in the production of timber, energy, medicines, fodder and foodstuffs for rapidly growing populations. Nevertheless, the general state of the production potential in these zones is characterised by continually degrading timber resources. In Senegal, between 1980 and 1990, the area of natural forest decreased by $10 \%$ and timber stocks fell by an annual average of 2 million $\mathrm{m}^{3}$, for instance. The problems generated by poor soil resources, are compounded by heavy pressures on ground water and inappropriate management practices which extract only the best trees, leaving a deteriorating genetic base in place. The old patterns of land use in rural areas have become all but impossible to sustain, and a transition is underway to systems where cultivation, grazing and browsing, and the harvesting of forest products, must all take place simultaneously. Continued provision of expected goods and services, and land-use sustainability will thus be a challenge.

In many areas, the transition is thus away from forest in any formal sense of the word. Many such formerly forested areas are deteriorating in terms of their composition and diversity, and are characterised by ageing populations, the presence of dead trees, the almost complete absence of individual trees in intermediate ageclasses, and of new natural regeneration. The future of these areas lies in the hands of young people, particularly women, because of the role they play in collecting, processing, marketing and renewing timber and non-timber forest products. In this context, forest management cannot mean the management of large areas of forest, but (for as long as direct dependence on the land remains necessary for many rural people), must evolve towards the participatory management of rural space, forest remnants, wooded parklands, and such new trees as may be reintroduced into the landscape. 


\section{Administrative reform}

The 1990s brought major changes in the international economic climate and the donor framework within which most of the Sahelian economies function. Structural adjustment programmes were widely imposed by the World Bank and IMF, forcing governments to review policies and expenditure right across their activities. There has also been an increased questioning of the role of government and the centralisation of activities. Among the results of these and other pressures on the Sahelian countries have been cutbacks in state expenditure and a move towards decentralisation of many state functions.

Senegal was the first Sahelian country to experiment with decentralised government, taking the first steps in 1972 when it made provision for the election of local councils. These have legal title to their own natural resources but are under a high degree of central government control, especially as regards woodland management. In Niger, a legal framework for the establishment of local communes was set up in 1964 , but barely in place by 1994. The legal framework for decentralisation in Mali was created in 1991, and elections for Rural Councils, each covering 10-20 villages, were held in 1999. Sudan also has a system of elected Rural Councils but, to date, these have few powers over forests and natural resources. The Councils are large, each comprising a hundred or so villages, but, unlike West Africa, Sudanese legislation allows individual villages to become statutory owners of their woodlands.

These decentralisation moves have obvious limitations as far as truly local representation is concerned. The fear is that local governments will sell the natural resources over which they have control in order to fund their own running costs. Whereas it is in the long-term interest of villages to use their resources sustainably, since they will be faced with the consequences of not doing so, elected officials may be less concerned (Kerkhof 2000).

One of the common criticisms of forest services is that they are single sector organisations in charge of multi-sector resources. Forest services have been generally slow to respond to such criticism and by 1999, no significant sociological, economic and environmental expertise was to be found in most of the Sahelian forestry services. Instead, a variety of environmental and other multi-sectoral agencies have been established throughout the Sahel. National environmental action plans have been prepared in a number of countries and in both Sudan and West Africa, environmental committees and secretariats exist, though they are weak. In Sudan, the recently established system of devolved federal governance is much more promising and under it locally elected Rural Councils may be empowered to support the village forest registration process. 
Although progress has been slow and patchy, there has been significant change and a broadening of approach with the notion of land resource management as a sectorally integrated concern slowly gaining ground across the Sahel. There is a real sense of transition, with interesting possibilities opening up in the management of community woodlands.

\section{The role of the forest service}

Major questions nevertheless remain over the continuing role of the forest services that limited their scope for broad-based effective action at a community level and retained much of their legal power. There is no doubt they will retain their authority over gazetted forests, either through traditional policing and management, or through joint forest management schemes in which local user groups play a strictly defined and controlled role. In the meantime, many younger foresters are interested in training and extension rather than policing, and some leave the service and work for other institutions such as NGOs.

Changes in climate and population density and their impact on the relationship among forests, farms and livestock

One recent major study has been focussing with great clarity on dynamic changes going on in the Sahel forests (Tiffen and Mortimer, in press). Focussing on northern Nigeria, southern Niger and Senegal, the authors and their collaborators show how creative adaptation to change has been in the narrow Sahelian dry forest belt.

During the period since the 1970s, southern Niger, north of the Nigerian border, has faced declining rainfall; increasing competition for land resources because of population growth; growing shortages of animal manure and crop residues needed to maintain soil fertility; and labour shortages attributed to the rapid extension of cultivated areas. Total rainfall has diminished on average, and the season has tended to become shorter and less reliable.

Over the last 12 years, populations densities in the drier northern part of this area (Maradi district) have gone from 23 to 44 people per $\mathrm{km}^{2}$, while in the southern slightly less dry arrondissements, densities have risen from 49 to 68 people per $\mathrm{km}^{2}$. Farmers have moved north and transgressed the line that is intended to demarcate the exclusively pastoral zone. The proportion of village lands under cultivation had risen steadily. In the 1980 s there were still some areas unallocated by village leaders, but these are now all gone. Land in the Department is now at saturation point. Livestock numbers have been maintained or slightly increased, but these animals are managed more and more on the farm.

The loss of common property resources has led, to increased focus on the household as the decision-making unit at the expense of the power of local rulers and the extended family. Labour migration is increasingly widespread, long-term and long- 
distance, and women have had to take on more responsibility for managing farms and maintaining household consumption. However, data collected during the 1990 s shows that farmers in Maradi Department have adapted to long term rainfall decline, drought and high demographic growth, while maintaining production and yields, increasing on-farm tree densities, and making other investments in land resources, transport and other off-farm income generating activities. Farming households have adapted to climatic and demographic changes by introducing new seeding and cultivation methods, new crop varieties, and a wide range of soil fertility conservation measures.

They have responded to an uncertain economic environment by identifying new markets and new crops. As elsewhere in the Sahel, low-lying soils (clay) have been brought from neglect into intensive use. The dry valleys of Maradi Department which supported much woodland fifty years ago, are now entirely under cultivation. Trade forms an important part of income strategies, and there is an intense exchange of goods and labour between Maradi Department and Nigeria.

Decreases in farm size have led to more available labour. Some is directed to labour migration, but some may be available for more intensive activities on farm. Where this is the case, labour has been invested in the maintenance of soil fertility (the management of manure and crop residues) in tree management on farms - a little planting, but mainly the management and protection of natural regrowth - and to changed methods of livestock feeding. Animals may be fed on crop residues for nine months of the year, or may be sent south to Nigeria for part of the year. Fallowed land, once a communal resource, is now being privatised by its owners for animal feed.

\section{The role of local people}

The key to successful community resource management is the legitimacy of local governance among the major groups. In this context, legitimacy effectively means being compatible with local perceptions of social and cultural justice. If a forest management practice is to be right in the eyes of local people, it must conform with generally accepted customs and with local knowledge. If it is to meet these criteria, it must, almost invariably, be a locally-negotiated forest management system.

In the process, certain stakeholders will lose. Town-based traders and artisans, for instance, will be excluded from tree cutting or may have to pay fees. Though charcoal-making is often considered locally legitimate, when public land is under state control, it can be highly destructive in some woodland areas. In the wake of genuine local governance, communities may no longer accept charcoal production if it threatens the sustainable production of fruit, wood and fodder, and charcoal producers in the local community may find that they have to undertake other dry season activities. 
Pastoralists have in the past been under-represented, or entirely neglected, in most woodland management planning. It is now being increasingly recognised that pastoralists play a highly important role in the socio-economic and ecological dynamics of many areas. It is therefore essential that they are given fair representation when new woodland management approaches are being considered, and a much greater degree of involvement by pastoralists is presently being pursued in a number of projects. In Niger, for example, the pastoralists using the Takieta forest have met to plan forest management with the adjacent agricultural communities and external stakeholders. In the PAGE project in Mali, two active Peuhl pastoralists were hired to help guide interventions.

\section{Building on actual capacity}

Significant capacity for local forest management already exists and is being exercised in a large number of areas. In many cases, woodland management tasks are being carried out more effectively by local communities than by the forest service with which formal management responsibility rests. It is essential therefore that future efforts to promote natural woodland management build upon and strengthen existing local capacities. Experience shows that the ecological and social benefits are real. Villages in Mali which previously were prevented from managing their local woodlands are now managing these same forests effectively. Sudanese villages which have gained control over their local woodlands are conserving them and benefiting from them, and neighbouring villages are looking for ways of becoming recognised local woodland owners themselves.

Most Sahelian communities now have the capacity for managing schools, credit schemes, water pumps and medicinal stores. While these capacities may not be available for woodland management at all times, they provide a basis for tasks such as planning management, monitoring that management, and suing a transgressor in court. If woodland management is locally recognised as providing community benefits and the institutions involved are representative of key user groups, the required capacities are available if they are needed. While such capacities do not entirely substitute for other authorities with responsibilities for Sahelian dry forests, the weak capacity of forest and environment agencies and the strong interest of woodland users, are now beginning to be drawn into a more productive complementary relationship. 


\subsubsection{Some achievements in forest management in Sahelian Francophone West Africa ${ }^{4}$}

This area has made several notable contributions to our understanding of forest management for particular products, and to the development of new institutional arrangements to support such management. The best-known are probably the 'forestmanagement-for-fuelwood' systems which have been established in Burkina Faso and Niger, working with local people and establishing rural co-operatives for the work. Cote d'Ivoire has tried other approaches to fuelwood production. Community logging has been tried in Mali with revenue shares split between State, Forest department, Village and fellers. Senegal and Mali have begun to work more actively with pastoralists. Finally, Chad has undertaken studies to enhance the production of arid land products such as doum palm, borassus palm and gum arabic.

\subsubsection{Factors limiting the effective management of natural forest}

Although there has been an improvement in knowledge and know-how, properly managed forests still represent a very small percentage of the forests of the dry zones of sub-Saharan Africa. This can be explained by a number of factors.

Management has not been adequately adapted to the dynamic and variable nature of the forests, or to the shortage of trained staff and funds. Medium and long-term strategic plans are also lacking, mainly because management activities have often been left up to projects, which cannot ensure either continuity of either management or data gathering.

There has been limited capacity to see forests as part of a more complex landscape and the separation of national ministries has meant little or no co-ordination of activities. Similarly, the capacities and goodwill of local communities were squandered rather than built on.

Finally, poor inter-country cooperation in West Africa has often led to the duplication of work - a folly for countries with limited human, technical and financial resources, and common problems with forest resource management.

\subsubsection{Suggested priority studies for dry forest development}

\section{Scope and context of implementation}

A range of areas of significant knowledge gaps can be identified for which studies are proposed below. For many, summary syntheses of existing knowledge by subject should be drawn up quickly, so as to help in setting up baseline data to allow the

\footnotetext{
${ }^{4}$ Country-by-country details are to be found in Annex 1.1 .
} 
identification of centres of excellence that could act as leaders and co-ordination centres. Accompanying measures for training and information are also of prime importance because it is essential to transfer technologies.

All studies are expensive, and require good quality staff. Yet the lack of human, financial and technical resources is the most common feature of research institutes in Francophone Sahelian Africa. One solution to this problem is greater collaboration, along the lines of the on-going establishment in the sub-region of national agricultural research systems (SNRAA). The main objective is to bring down the barriers between institutions and to promote the emergence of research teams prepared to work together.

With regard to research associated with people's involvement in management of dry forests, the general environment is relatively favourable because legal and regulatory aspects of forestry codes have clearly evolved towards the individual or collective ownership of trees, and the possibility of transferring rights to them. There is also a general context of democratisation, with populations assuming greater responsibility, which leads, amongst other things, to the transfer of competence in natural resources from the State to local councils, to the decentralisation of technical services (so as to improve training and monitoring of policy at local level) and to State withdrawal from sectors of production.

Prospects for pooling energies and resources among countries have in recent years been enhanced by greater sub-regional integration. Various networks link research institutes (INSAH/CILSS, CORAF-Forêt, AFORNET and FORNESSA), NGOs (RIOD West Africa) and farmers' and producers' organisations (ROPPA). All these offer opportunities for optimum implementation of concerted activities. Thus, on the basis of real partnership, and adopting a holistic approach, tasks and resources should be shared on the basis of competencies, expertise and comparative advantage. CIFOR should encourage and work with this process.

\section{Resource characterisation and evaluation studies}

Studies on knowledge of the character and extent of forest should be conducted which take into account non-forest tree dimensions. This would involve developing mapping and inventory techniques further. In ecological terms, and given likely future problems, better understanding and measurement of biomass rates should be one of the priorities for management. Such a landscape approach will lead to better techniques for the analysis of ecosystems and their management.

\section{Studies on the productivity and dynamics of forests}

This will mean collecting information on the structure and dynamics of forests, for better knowledge of the ecosystems and the way in which they function, using different tools (land use maps, potential maps, etc.). Particular emphasis would thus 
be put on studying growth, and the causes of death and regeneration.

Studies on techniques for forest enrichment may be particularly important because of the low productivity of the populations. This will involve using more productive germplasm and paying more attention to the natural processes of reproduction (stumps and root suckers) and traditional (grafting, cuttings, etc.) and modern (in vitro culture) techniques of vegetative multiplication. The establishment of permanent observation plots would be useful for testing various forestry techniques (coppice, coppice with standards, protection against fire, or early burning, full or partial closed areas, etc.) and the development of productivity tables.

The drafting of a management plan requires knowledge of productivity, which is often not available when projects start up. Indirect methods, such as the synchronic approach (studying populations of different ages in the same zone), or studying growth rings (measuring width) will give an idea of annual growth. The ultimate aim will be to understand optimal exploitation levels.

\section{Development and management of priority agroforestry techniques}

Emphasis must be put on inventorying, mapping and rehabilitating various existing agroforestry areas, whilst determining the essential physical, biological and socioeconomic factors behind their existence and evolution. Particular attention needs to be paid to:

- Making use of local knowledge and know-how on agroforestry management practices:

- Characterising the areas (typology, mapping, geographic distribution, dynamics);

- The biophysical aspects of tree/crop/animal interactions;

- Factors in the rehabilitation and intensification of these systems.

\section{Studies on plant biodiversity}

The priorities here are:

- Taxonomic diversity: species inventory, inventory of endangered species, methods of in situ and ex situ conservation, typology of the vegetation (composition, structure, etc.)

- Genetic diversity: intra- and inter-specific genetic variability;

- Functional diversity: species adaptation to soil and climatic conditions, resistance to the most obvious stresses, identification of indicators of the state of degradation or regeneration of the biodiversity in terms of plant species and some groups of species of mesofauna (termites, nematodes), and microflora considered necessary for the proper functioning of systems. 


\section{Studies on the domestication and more varied use of forest species}

These studies are intended to help the local population decide which species to protect or cultivate more intensively, so that the highest possible density of tree stocks is obtained. In terms of assessing the resource, this would require determining the available biological potential and better monitoring of population dynamics; knowing the level of variability within species, in order better to define the selection strategy which should lead to improved performance of the target species, in terms of both product quality (fruit, gum, fodder), and of production.

In terms of improving and managing forest species, it would require: selecting, with the assistance of local populations (participatory selection), the most productive phenotypes; having better knowledge of the biology of the target species; making sure that local people are familiar with methods of vegetative propagation in order to bring the species to earlier maturity and to clone selected germplasm to meet planting needs; improving tree management, both in terms of forestry techniques and of plant protection; promoting the use of these forest species in various agroforestry technologies, (thus helping to maintain and restore the plant canopy and soil fertility) whilst also producing marketable fruits.

In terms of agricultural production, it will mean determining the timing of harvesting, and establishing appropriate storage and processing methods.

\section{Studies on fallow management}

Tree-cover on fallow land is, in terms of appearance and structure, similar to dry secondary forest. There are practically no forest stands unaffected by human beings in the Sahel, and so it would seem that forest stands on fallow land are not very different from dry forests, even if there are particularities with respect to their status and management. Themes for research might include the following:

- Modelling production and growth of fallow forests has received very little attention, because of their unequal structure and multi-species composition;

- Measuring productivity raises a number of problems which have not found appropriate answers, and the results often disagree;

- The speed of improvement (after regeneration is protected) of degraded forest ecosystems and the possibilities for further improvement are not well known;

- The effects on the dynamics of fallow forests of different types of use (e.g. fire and grazing) has been little studied.

Future carbon markets offer interesting opportunities for carbon sequestration in Sahel forest systems, and are a unique opportunity to combine the objectives of two UN conventions, to combat desertification and climate change. However, these systems have not been assessed in terms of carbon sequestration, and studies should 
attempt to find species and models of the most efficient formations for carbon sequestration.

\section{Socio-economic studies}

A methodology should be developed to give a better understanding of the sociocultural dynamics that affect choices made by the local populations. The way in which local people currently manage and use forest has to be better understood before improved management and exploitation of forest formations can be designed. Once this logic is understood, activities could be better-guided and adapted to the priorities of the local populations. Hence the socio-cultural and economic value of trees, and the benefits they generate need to be assessed. Topics of research could cover:

- Ethno-botanic studies,

- The impact of timber and non-timber forest products on the well-being of rural populations;

- Comparative studies of farming and forestry income in farms;

- The determining factors in village community participation in management;

- The importance of property rights and rules of access to resources (land ownership system, forest and pastoral codes, etc.);

- The socio-economic and cultural criteria for the choice of species and use of forest products:

- On analysis of the costs and benefits of natural formation management.

\section{Application of criteria and indicators}

The options chosen in management plans will involve practices of which the trends and impacts must be monitored, as part of the learning process and adaptive management.

It is certain that the criteria and indicators adopted for Africa are relevant, since they respond to demand, to need, to an urgent situation and a requirement. Their appropriateness is not in question. The correct choices also have to be made in terms of their prioritisation, bearing in mind that a criterion or an indictor alone cannot be a measurement of sustainability. The trends towards sustainable management should be seen in the light of all the criteria and indicators. Cost is a determining factor.

A common approach must be adopted, taking into account the particularities, the degree of ownership and the state of knowledge in the country. First the applicability of the criteria and indicators will have to be analysed, emphasising potential sources of data and the possibilities, in time, of the indicators changing. Then the methodologies for the implementation of the experimental management units will have to be validated, to allow monitoring of the chosen indicators. The idea of a management unit will have to be interpreted at different scales, depending on local or regional conditions. 


\section{Building regional research relationships}

An urgent need is to develop inter-country and trans-regional research, so that approaches can be tested elsewhere and new findings rapidly disseminated.

\subsubsection{Conclusions}

With the growing need for timber and non-timber products, it is vital that policies be applied to preserving and improving forest resources for the provision of goods and services. Success may in many cases require giving greater responsibility to local populations so that they can effectively take responsibility for managing resources, supported by learning and transfer by the technical services of management tools underpinned by rigorous experimental research. Regrettably, these are not always currently available. Furthermore, the knowledge base on African forest formations is very weak and it is essential - and urgent - to include among focus areas the strengthening of data-collection capacity. This strategy necessarily involves strengthening the human, scientific, technical and financial capacities of research structures, and through a standardisation of approaches.

\subsection{Dryland Anglophone Africa North of the Equator - Sudan, Kenya, N. Ghana, N Nigeria.}

\subsubsection{Nature and condition of the dry forests}

According to the vegetation classification system developed by White $(1983)^{5}$, the following vegetation types dominate within the four countries in this section:

- Sudanian Woodland with abundant Isoberlinia (Northern Ghana, Northern Nigeria, Sudan)

- Undifferentiated Sudanian Woodland (Northern Ghana, Northern Nigeria, Sudan)

- Sahel Acacia woodland (Sudan, Northern Nigeria)

- Acacia wooded grassland (Sudan)

- Somalia-Masai Acacia-Commiphora deciduous bushland and thicket (Kenya)

- Semi desert grassland and shrubland (Kenya, Sudan)

In the FRA $2000^{6}$, the regional overview broadly follows the above vegetation types, highlighting the following:

- In the Sudanian region: woodlands with Acacia albida, A. macrostachya, A. nilotica

- In Sudan: woodlands with Anogeissus leiocarpus. Where cultivation is possible, most of the land is bush fallow. Permanent or semi-permanent cultivation is being practised around the large towns

\footnotetext{
${ }^{5}$ White $F(1983)$ The Vegetation of Africa. Orstom-Unesco, Paris.

${ }^{6} \mathrm{FAO}$ (2000) Forest Resource Assessment 2000. www. fao.org/forestry/ - FORIS database
} 
The dry tropical forests, including woodland, savanna and steppe formations, are located in areas dominated by subsistence agriculture and rangeland supporting large numbers of livestock. Pressure on these forests is heavy in many places due to agricultural expansion and increased fuelwood collection and livestock grazing (State of the Worlds Forests, $1997^{7}$ ). Planting efforts in the dry areas of the region have been focused on meeting wood energy needs and controlling desertification, but efforts in the 1970s and 1980s to increase fuelwood production and reduce consumption, were not as successful as hoped. Lessons from past experience indicate that the most successful means of increasing fuelwood production are through locally based, sustainable management of natural forests, well designed and managed plantations, and agroforestry practices. Natural forest management in dry areas of the region has only recently received significant attention, but community forestry is well-developed in the Sahelian west, and Sahelian east.

\subsubsection{A review of experience with the management of dry forests/woodlands}

This section looks at experience in management of forests and woodlands over the last 10-20 years, identifying promising technological approaches that seem to work, and the conditions under which they seem to do so.

\section{Regional issues}

Much research in the region has pointed to issues of pastoralists, devolution and the commons. The paper 'Who's Managing the Commons - inclusive management for a sustainable future' (Hesse, $C$ and Trench, $P, 2000^{\circ}$ ) indicates that not only are decentralisation initiatives failing to take into account the differentiation in rural communities (rich, poor, temporary, permanent, male, female) but that mobile communities are being left out of the process of defining local resource management systems.

Some of the conflicts are becoming more violent, key exacerbating factors including a history of centralised state control which has removed responsibility for NRM and conflict resolution from local people; rising populations and drought, leading to increased competition for resources, and their privatisation, to the exclusion of others from the resources on which they have depended.

Hesse and Trench identify various constraints to decentralisation within the Sahel. They note piecemeal reformulation of existing sectoral policies without changes being made to the institutional framework, for instance. Packaging land use systems into sectoral entities bears no relation to how the resources are actually used/managed. The piecemeal approach leads to confusion and contradictions within the government

\footnotetext{
${ }^{7}$ FAO (1997) State of the Worlds Forests. www. fao.org/forestry/

${ }^{8}$ Securing the Commons series No. 1, IIED London
} 
ministries. Even where decentralisation is occurring, there is often a desire by the state to produce a set of national rules to regulate NRM at the local level. The report notes the need for a legislative framework but a more local set of rules to govern use which reflect the diversity of land tenure practices at the local level. Many decentralisation approaches tend to stop short of devolving power and authority as well as responsibility.

Many of the concerns/constraints raised in this paper are echoed by Ribot ${ }^{9}$. He notes that, in the forest sector, almost all the arrangements for decentralised NRM involve creating management committees with some direct relation to local governments and the forestry service. However, the committee does not necessarily represent, and is not accountable to the local population. Many examples of decentralisation have shown that new laws give local authorities the right to manage NR but the management plans and requirements are still imposed by central agencies. There are many examples of the creation of elaborate and overly complex planning and registration procedures.

\section{Some achievements in forest management in Anglophone Sahelian Africa ${ }^{10}$}

Ghana and Nigeria have both focussed much of their attention on savanna and transition zone development and restoration, in the light of the very heavy demands made on savanna for urban fuelwood and charcoal due to the growth of urban centres and the spread of small scale beer brewing. Regional Governments have introduced taxes on loads of fuel and charcoal entering major settlements. They do nothing to discourage the trade as it is a useful source of income. Interesting research has also been undertaken on savanna sacred groves and their biodiversity in northern Ghana (UNESCO, and Blench, ODI).

The Sudan has early experience (from 1985 onwards) of working with local people both in communal planting of shelterbelts to retain sand and hold it away from riverside agricultural land, and in natural forest management. In areas where local management is allowed, the woodland is usually well protected. Guards may be employed by the local community and paid through fines or revenues from sale of forest products. Rules under which woodlands are protected vary and are a function of local, physical, economic and institutional factors. Sudanese law states that forest committees elected by villages are in charge of local woodland management.

Kenya's Ministry of Environment has highlighted the need to focus more on dry forests, protected until now by pastoralists, and the main focus of donor funded NR

\footnotetext{
${ }^{9}$ Ribot, J (2001) Decentralised Natural Resource Management - Nature and Democratic Decentralisation in SubSaharan Africa. A Summary Report prepared for the UNCDF symposium on Decentralisation of Local Governance in Africa.

${ }^{10}$ Country-by-country details are to be found in Annex 1.1 .
} 
projects in Kenya is on rangeland and arid and semi-arid land issues, with a number of projects funded through GTZ, and CIDA, and research by IDRC.

Ghana, Nigeria and the Sudan have all enacted legislation to enhance the capacity and the right of local people to manage nearby forest. Kenya has refused to take this path, preferring to retain forest in the hands of the Kenya Forest Services or local authorities.

\subsubsection{Issues of scaling up and adoption of best practice}

This section attempts to identify why specified approaches to promote sustainable management of dry forests have not so far succeeded on any major scale and the main barriers to the adoption of these approaches.

Several of the reports mentioned in the previous section have pointed to issues that need to be addressed to enhance the effective management of dry forest resources. For instance, even though decentralisation is taking place, many procedures are still centralised and bureaucratic, slowing down the process of devolution. The decentralisation of power from forestry departments to local populations challenges government and implies modifications to management itself which have not yet been fully embraced or recognised. There is poor understanding of local diversity and the complexity of tenure, and of traditional farming systems, land management and livelihood systems, and their rapid evolution. There is conflict over increasingly scarce resources.

\subsubsection{Donor support}

There has been fairly limited new research or project support in the Anglophone Sahelian dry forests in recent years, by comparison with that undertaken in the miombo woodlands south of the equator, and with that in the Francophone Sahel (Reports to the World Forest Congress, $1997^{11}$ include a number of case studies on dry forest management but most of these come from Benin, Burkina Faso, Cameroon, Chad and Niger).

Though several donors have continued work on projects linked to desertification, much of the focus has been on Kenya. The Sudan has been unable to obtain almost any donor funding, except through one or two NGOs, since the 1991 Gulf War, (though it looks likely to be rehabilitated shortly). Nigeria has received minimal funds, partly for poor governance reasons. Both northern Nigeria and northern Ghana have suffered from the fact that such forest donors as they have been able to attract have been drawn to the tropical moist forests of the southern parts of the countries concerned.

\footnotetext{
${ }^{11}$ Final Report and Recommendations (Chapter 7) and Topic 38.4 'Dry Tropical Forests'. http://www.fao.org/montes/foda/wforcong/publi/
} 


\section{Regional initiatives in Anglophone Africa north of the Equator}

\section{Donor initiatives}

GTZs main focus is on desertification projects and it has a number of such projects in Kenya. It also has a reforestation project in the Volta region of Ghana. CIDA, through IDRC, has approached desertification through assistance in the development of National Action Plans. IDRC is funding research on the theme People, Land and Water in East Africa and the Middle East. DFID has funded several workshops and a project through FRP entitled 'Enhancing the Role of NWFPs in the Livelihood Strategies of Smallholders in Semiarid Kenya'.

\section{Initiatives of the International Agricultural Research Centres (IARCS)}

The International Agricultural Research Centres active in this sub-region are ICRAF, ICRISAT and ICARDA. ICRAF focuses on the semi-arid lowlands of West Africa-Burkina Faso, Mali, Niger, Senegal; ICRISAT focuses mainly on crops and agricultural resources for the semi-arid tropics.

ICARDA has produced a number of relevant documents including 'Mapping Rural Poverty and Natural Resource Constraints in Dry Areas' (Rodriguez, A., Thomas, N. 1999. ICARDA Social Science Paper No. 6. 24 pp.) This study discusses rural poverty and natural resource constraints in dry areas using graphic representations of socio-economic and naturalresource endowments or constraints. Because maps are easier to understand and use than tabular or statistical presentations, maps were produced for dry areas, population density, environmental dimensions (availability of arable land and fresh water), child malnourishment, agricultural labour force and social dimensions (number of poor people adjusted for the severity of poverty). It has also published Dryland Biodiversity Conservation through Natural Resource Management (Summary workshop Proceedings, 5-9 Feb 1995, Amman, Jordan. Peacock, J.M., ed.). The book focuses on suitable practices for the maintenance of biodiversity through sustainable management of natural resources.

\subsubsection{Priority issues}

A number of issues should be given more attention in research. Their identification builds upon a number of regional workshops convened by various organisations, to identify gaps in knowledge and possible priority areas for further research. Findings from three such workshops are summarised below.

The FAO Forest Outlook Study for Africa (FOSA): the initiative, which includes data collection and country studies on existing information and possible futures for forestry in the region, has supported several workshops as a prelude to the writing of the Outlook study, to discuss data collection and future needs. The Kenya workshop was based on the Kenya Forestry Master Plan, and worked especially with the Kenyan Forestry Department and IUCN. The workshop report concludes that 
there is a serious shortage of data regarding forests, and a need to improve information management capacity.

The Sudan workshop and report was orientated to non-wood goods and services, and was based mainly on official government statistics. The data provide a detailed account of the importance of NWFPs in Sudan and exemplify the kind of data collection possible.

The Sudan Workshop: A workshop entitled 'Management of Trees for Farmland Rehabilitation and Development'was held in Sudan (27 October - 7 November 2000) arranged by University of Helsinki, DFID FRP, and the African Academy of Sciences $^{12}$. Participants included representatives from Universities and Forest Institutes in Sudan, Forestry Research Institute of Ghana, Ministry of Food and Agriculture (Ghana), Kenya Forestry Research Institute, other Kenyan research institutes and Universities and the University of Nigeria. The recommendations included the need for reliable knowledge on ecology, growth, performance, product characteristics and economic value of local species to be made available for decision making on rehabilitation options; research prioritisation to fill in the gaps in this knowledge and prioritisation of the need to process and market products from tree species, which should shape decisions about their management and utilisation. The workshop also cited the need for urgent action to register the uses of the important tree species in tropical dryland ecosystems; and for more support to in-service training and curriculum development, especially in sustainable agriculture, sustainable forest management, and economic valuation of forest and tree products and services.

This list lines up very closely with the priorities identified for the Francophone Sahel.

\subsection{Dry forests in Southern Africa}

\subsubsection{Regional overview}

The woodlands in the region are dominated by miombo woodlands, which are absent only in Namibia, Botswana and South Africa. The woodlands are characterised by the predominance of Brachystegia spp. in association with Julbernardia spp. Rainfall ranges from around 750 to $1150 \mathrm{~mm}$ per annum. Miombo woodlands include all Southern and Central African ecosystems which occur under a hot, sub-humid, seasonally wet climate on soils derived from acid crystalline geology. Woodland in the remaining three countries is dominated by Kalahari-type vegetation but varies from country to country.

${ }^{12}$ University of Helsinki website - http://honeybee.helsinki.fi/tropic/recommendations.htm 
The Miombo woodlands cover approximately 5 million $\mathrm{km}^{2}$ and support over 100 million people with food, fuel, building materials etc. ${ }^{13}$ The region has a fast growing population ( $>3 \%$ per annum) and over $80 \%$ of these people still live in rural areas depending mainly on traditional agricultural practices. ${ }^{14}$ Dewees (1996) highlights the following information on the current extent of miombo woodland in the region: heavily modified miombo accounts for more than $95 \%$ of the existing woodland cover in Malawi; mature miombo in the Tabora region of Tanzania is mostly regenerated; oncecultivated areas of Zimbabwe which were depopulated during the early $19^{\text {th }}$ century eventually regenerated into extensive miombo areas.

\subsubsection{Review of experiences with the management of dry forests/woodlands}

This section reviews experience with the management of dry forests/woodlands over the last 10-20 years, with broad identification of promising approaches.

A number of projects/reports have concentrated on the policy and institutional issues relating to woodland management - the changes which have taken place in the past decade and the issues which need addressing. In addition to the policy framework, some authors have questioned the purpose of research into woodland management - and suggest a shift from how to why and by whom.

\section{Thematic and multi-country experiences}

A recent paper by Alden Wily (2000) $)^{15}$ reviews recent changes in government policy in the region and the experience with decentralisation. It builds on a previous review of institutional arrangements in $1996^{16}$. In the 1996 review of institutional arrangements, the experiences from various case studies pointed to elements of 'desirable institutional change' being suggested to include a shift in locus of control from central government to local level; a change in the institutional framework within which woodland management is administered from state institutions to local; a change in the conceptual framework within which woodland management is conceived and developed to one which supports the functions of woodlands in the household economy and local society; a change in the mode of woodland management from the 'policemen' regime to one where the user has the incentive to be self-regulating.

In parallel with the above, other activities should be initiated including policy reform (to empower communities to control and utilise resources within their areas); legislation that allows and promotes proprietorship for woodland management to local

\footnotetext{
${ }^{13}$ From: Miombo Network homepage - http://miombo.gecp.virginia.edu/

${ }^{14}$ From: ICRAF online - www.icraf.cgiar.org/regional/region_2/region_2.htm

${ }^{15}$ Alden Wily, L (200) Making woodland management more democratic: Cases from Eastern and Southern A frica. IIED Drylands Issues Paper no. 99, IIED London.

${ }^{16}$ Matose, F and Wily, $L$ (1996) 'Institutional arrangements governing the use and management of miombo woodlands' in Campbell, B (ed) The Miombo in Transition: Woodlands and Welfare in Africa. CIFOR, Bogor, Indonesia.
} 
institutions; investment in rural resource management; institutional reform and capacity building at the local level.

A paper by Dewees $(1996)^{17}$ reported on the need to refocus management approaches of forest departments onto approaches which would improve the productivity of the woodlands for local needs. Citing example of local use of miombo woodlands from Tanzania, Malawi, Zimbabwe etc, uses include bee-keeping and honey hunting, a source of wild fruits and fungi, dry season livestock browse etc. Therefore, forest department approaches could be reoriented to focus on issues such as improving browse production, increasing leaf litter production, increasing nutrient content of the leaf litter etc. In other words, the author suggests a shift from approaches that solely consider how to manage forests, to those that also look at why and by whom.

Governments are generally seeking to return control over woodland resources to the communities who depend on them. However, whilst in some cases there may be a presumption that earlier community controls were used and were effective when this was not the case, in other cases governments may give control which far exceeds the local capacity for management.

There is a need to look at equitable mechanisms for devolving NRM to ensure that the above does not occur or that control is not given to a local elite who use the woodlands for immediate gain.

The paper also raises the issue of markets for products from woodlands and the limited range of policy instruments that can influence how they operate. Such policies are often geared towards limited supplies - control regimes, licensing, royalty collection etc. These policies, the author suggests, are based on the assumption that commercial harvesting damages woodlands - something the author disagrees with in relation to the harvesting of many extractive products. Local management would be more effective if markets operated in a way which encourage sustainable use.

Where areas have been settled for a long time, the institutions have had time to adapt to the changes imposed by increased population pressures. Problems are more likely where people have resettled where the lessons learnt are not accessible and they have moved to areas of different soils, climate etc. Productivity will fall and other consequences (such as malnutrition) will continue until households develop adaptive responses to environmental stress. Longer term costs of the loss of woodland cover must be assessed during stages of national planning.

\footnotetext{
${ }_{17}^{17}$ Dewees, P A (1996) The miombo woodlands of southern A frica: emerging priorities and common themes for dryland forest management. Commonwealth Forestry Review 75 (2) pp 130 - 135
} 


\section{Process and progress in the dry forests of Southern Africa ${ }^{18}$}

The countries of the Southern African region are experiencing enormous internal change in the legislative frameworks within which forests are found. But they perhaps have less imposed change to adapt to, in the form of changes induced by desertification, in-migration and sedenterisation of the kinds being experienced in the Anglophone and Francophone Sahelian dry forest countries.

At one end of the spectrum we find countries like Namibia and South Africa, which because of the fundamental changes of the last decade have committed themselves to placing community welfare, in the forest context, among their central concerns. In the case of Namibia there is commitment to decentralised decision-making, and though further adjustments are needed (experience in local management to date suggests that local natural resource management committees are finding they do not have adequate powers to be effective) they will come.

South Africa produced a National Forestry Action Programme in 1997 and a National Forest Act in 1998. The Department of Water Affairs and Forestry has assumed responsibility for the sustainability of woodlands as a distinct resource, is identifying threats to and enabling conditions for SFM, making use of C\&I to do so, and is also looking at developing management partnerships between communities on communal lands and private landowners.

Botswana conducted a countrywide review of the (1968) National Forest Policy and Forest Act between 1995 - 1997and has now produced a new draft policy which 'encourages, involves and assists local communities in the conservation, management and sustainable utilisation of forest resources'.

Tanzania has developed - very much through experimentation from the bottom up begun a decade ago and with some of the more successful outcomes of the ujamaa period still somewhere in the background - a new Forestry Policy in 1998 and the Bill for a new Forest Act. This calls for 'the delegation of responsibility for the management of forest resources to the lowest possible level' - including both district and village councils (unique to Tanzania). Tanzania has also incorporated Village Land Reserves into the Bill where land can be owned by villagers in common and registered as commonhold. Village and Community Forests will be autonomously managed.

Zambia, on the other hand, though it developed a new National Forestry Policy (1998) and Forests Act (1999), has made a clear distinction between local and national forests and is allowing community involvement - even JFM - only in local forests. There seem to be several impediments in the path of more devolved and equitable management here.

\footnotetext{
${ }^{18}$ Country-by-country details are to be found in Annex 1.1
} 
Zimbabwe is the most complex case in the area. Because of the large proportion of its best lands which have been held till now in large commercial farms, the 'communal areas' are artificially over-populated, and the forest resources in those areas are excessively heavily used. It has been difficult to establish communal management systems under such circumstances - the result has often been either a series of open access regimes, or attempts at illegal resource privatisation. At the same time, paradoxically, Zimbabwe is well known for the CAMPFIRE project, which has been seen as one of the leading communal management projects, and which is widely imitated.

\section{Southern Africa Dry Forests : Donor initiatives}

FINNIDA - Zambia Project

The second phase of this project started in 2000, designed to implement the forestry programmes drawn up in Phase 1. Areas of concern are Luapala, Copperbelt and Central Province. The objectives: To develop forest management knowledge, skills and tools among village communities, businesses, NGOs and the forestry administration. The strategy has been to decentralise decision-making and to develop a common forest model in accordance with the new forestry policy adopted by Zambia.

GTZ has supported Mozambique: in the 'Dry Zone Africa Process' which includes regional discussions on Criteria and Indicators for Sustainable Forest Management for SADC Countries. This is supported as part of GTZs 'Building Capacity in Forest Certification' which also includes Malawi, Namibia, South Africa, Zambia, Zimbabwe, Angola and Botswana

DFID works in Malawi on the management of Miombo woodland as community woodlots and has also co-funded the Malawi NFP. It has a wide range of activities in South Africa.

NORAD Malawi: a SADC project to provide inexpensive fuelwood using environmentally sound methods to a poor urban population (the Blantyre City Fuelwood Project). Recent developments in the project show that the local community have now taken full responsibility for managing the forest resources, apparently successfully.

DANIDA Tanzania - ongoing project on Community Based NRM in Iringa Rural district which aims to safeguard the future existence of the natural woodlands and the benefits to local communities. In Zimbabwe a project on Small Scale Forest Product Enterprises is being conducted, locally managed by the NGO SAFIRE. The goal of the project is to promote economic development based on sustainable and productive use of natural resources in communal and resettlement areas of Zimbabwe. 


\subsubsection{Apparent causes of SFM failures to upscale or get adopted}

There are indications of a number of causes why specified approaches to promote sustainable management of dry forests have not so far succeeded on any major scale and the apparent main barriers to the adoption of these approaches.

A recent CIFOR report [CIFOR brief (No. 5)] raised many of the problems raised by other authors in their reviews of the experience with sustainable management in the region. Whilst it is apparent that more donor funding has been provided for countries in this region than in Kenya, Sudan etc., there are still variations within the region. Tanzania has been a focus of much attention, as has Zambia and Zimbabwe. The current situations in Angola and Zimbabwe are both highlighted as having impacts on projects trying to develop NRM and on the legislative/institutional arrangements.

Devolution to the lowest level: Generally, it seems that although countries are moving towards decentralisation, the devolution of authority is not going low enough. Only in Tanzania are there any examples of laws in place which would enable village/community authority. The CIFOR review of CBNRM indicates that without such a shift in power, these CBNRM/sustainable management approaches will not succeed.

Strengthening of local/traditional institutions. In parallel with this is the need for capacity building/strengthening of local and traditional institutions - to have the ability to manage their resources, develop effective relationships with central administration and have the authority to enforce their rules. This situation appears not to be happening and several reports cite the lack of capacity in the traditional institutions as one of the barriers to effective management. The research in Zimbabwe reviewed in CIFOR brief 4 highlights the fact that local people generally have great respect for these institutions but that they need strengthening in order to become more effective. 


\section{Southern Africa Dry Forests : AIARC Initiatives}

ICRAFRegional Programme Subhumid unimodal plateau of southern Africa. Aims to generate agroforestry technologies and research the domestication of indigenous fruits. Research highlights include soil fertility improvement research - looking at alternative coppicing species; rotational woodlots - these integrate trees into existing cropping systems for multiple products including fuelwood, fodder, soil fertility improvement etc.

CIFOR/EC/SADC project. A research project entitled 'Management of Miombo Woodlands' was initiated in 1998 in joint collaboration between CIFOR and the EC. The project is being implemented in Malawi, Mozambique, Tanzania, Zambia and Zimbabwe. The project builds upon a smaller 18-month project (also CIFOR) which focused on policy influences on local communities living in the proximity of the miombo woodlands as well as local community livelihoods potentials in the woodlands. Some of the most interesting issues raised so far include:

- Income from the sale of wood products was becoming increasingly important to households with a change form $6^{\text {th }}$ position in 1993 to $3^{\text {rd }}$ in 1996.

- Joint management was viewed by local communities as an alien concept and as a top down approach. There is still suspicion amongst villagers regarding the intention of the government in involving them in management. (Brief No. 3 1999)

- Although traditional institutions have been eroded, they are still strong relative to other organisations and have the best potential for mobilisation of NRM. Local people have respect for these structures.

- The notion that traditional structures need strengthening so they can build on this and effectively manage NR has been echoed by several authors. (Brief No. 4 1999)

- There is a very interesting analysis of state of CBNRM in the region.

Lack of information on the woodlands: An issue raised in several cases points to the lack of basic forest information - cover, benefits for local communities etc. Without this basic information, researchers point to an inability to effectively inform decision makers of the situation in the forests and possible steps needed to improve management. The FAO statistics on forest cover change for many countries have been extrapolated from much earlier data as there is no up to date information.

Information on NTFPs. Several projects have indicated that whilst many traditional extractive resources (timber, charcoal etc) have values associated with them, others such as honey, oils etc have not be subject to as much research and there is little information on what constitutes 'sustainable extraction' of these products. Therefore, projects which have developed small-scale enterprise based on these products have faced difficulties in sustainably accruing benefits from the sale of the products as alternatives to traditional extraction.

Markets: Linked to the lack of information on sustainable production for NTFPs is the issue of access to markets. Many projects have cited the limited access to markets (including fuelwood) as a restriction on the success of the project. This is 
of particular concern for the DANIDA project in Tanzania - without these markets, will the value of the products be able to exceed the value from clearance and agriculture.

\subsubsection{Issues needing more attention in research}

Some of the issues which could benefit from more attention in this region reflect those mentioned for other regions. Possible areas for research raised in the review of experience in this region include:

- Basic data on forests and forest cover

- Reliable knowledge on the ecology, growth, performance, product characteristics etc of local species

- Information on sustainable harvesting of local NTFPs

- Identification of what species are important to which households, why and what affects any change?

- Marketing of products - access to markets and market incentives to manage sustainably

- Once the basic information exists - how to improve production of NTFPs.

\subsubsection{Key socio-economic issues in the dry forests of Southern Africa}

The Southern African dry forests have been much better researched recently, in many ways, than their equivalents north of the equator. This is the result of research which CIFOR itself has been and is conducting; the result of some fine active researchers in the region based in universities in Harare, Dar-es-Salaam and South Africa, and the result of the IUCN-supported work on Community Involvement in Forest Management, among others.

It is also the result of recent donor focus. Whereas the 1980s saw a huge donor concentration on the dry forests of the Sahelian zone, donor interest has very much swung, since 1990, to the SADC countries and to Southern and Eastern Africa more generally. Changes which were perhaps beginning to occur in this region anyway, have been both supported and magnified by donor presence and donor funds.

What is perhaps still needed within the area is:

- More attempt to gather cross-country comparative experience

- A better understanding of the level to which government forest governance attempts need to be devolved, the better to support local efforts at forest management

- The extent to which land reform/legal change is needed

- A better understanding of intra-community processes. 
Behind these lurks a much larger and more important research question, which it is impossible to research in Southern Africa alone: what are the drivers which would seem to have made certain forms of community management of forests far more successful in the Sahelian context than in the southern African one?

Does the slightly higher rainfall in the Southern African area make forest relatively less important as a fall-back resource than it is in the Sahel, so that people are less inclined to invest effort in its management? Does the enormous dependence of cattle on forests in the Sahel valorise the forest in a different way from the southern African forests? Are peoples who have developed strong lineage structures (a result of transhuman of cattle-management, according to some) better able to manage forest among themselves and more able to command obedience to the rules than fully sedentary, individualist farmers in Southern Africa?

Devolution, decentralisation, the involvement of local people in forest management are the leading concepts in forestry at the moment - yet we still hardly know what we are trying to create, and how possible it is to do so.

If the full picture which is now emerging in southern Africa can be combined with data from past efforts in the Sahel - and updated with new findings - SIDA and CIFOR will have made a unique contribution to the literature.

\subsection{Conclusions, comparative issues and recommendations}

Four or five broad thematic research areas emerge as urgent from this review of the current state of play in dry forests in Africa, and the work being undertaken in them. They are as follows.

\subsubsection{How do we measure and monitor the role of forests in the livelihoods of the poor and how do we aggregate to national level?}

In Africa, above all, forests play a fundamental part in the national economy and form a substantial part of the livelihood of large numbers of people. However, methodologies for aggregating up the contributions to livelihoods that forests make, and factoring them in at national level have not as yet been elaborated. This research topic will seek to rectify this gap.

The contribution of forests to the livelihoods of rural people in dry forest countries, and the economy as a whole, is consistently underestimated. It is proposed that, in the case of 3 or 4 selected African countries, as full a calculation as possible is undertaken, to assist with the recognition and validation of such forests.

- In the case of each country selected, review available written materials about the relationship between forests and local people.

- In the case of each country selected, supplement this review with field-based 
analyses conducted through direct data-gathering, of the contribution of forests:

- to the livestock economy;

- to household energy;

- to household food supplies around the year

- to the household budget through sales of fuelwood, NTFPs, cooked or preserved food;

- as a source of wages

- as an aspect of small-scale rural industries (beer brewing, brick making etc);

- as an aspect of food preservation (fish and meat smoking, constructed grainstores, etc);

- to sustainable water supplies

- In collaboration with university researchers, interested government officials, and international experts, develop methodologies for aggregating data from the desk and field reviews up to usable national level data

- Bring findings for discussion and debate at national level workshops where the actual value of apparently low-value forest can be reassessed.

- Bring findings for discussion and debate to international-level fora including the $C P F$ (monitoring and reporting), the CBD, development banks and aid agencies, and research institutions.

Possible countries to be selected for this research area:

Since this research topic feeds into Topics 2 and 5 (below) it is important to select countries from both the Sahelian and the Southern African areas, and to capture a range of diverse types of livelihood dependence on forests in the process. In the case of Southern Africa, there is data to build on in Zimbabwe, Zambia, Mozambique, Malawi and Tanzania. North of the Equator, Burkina Faso, Mali, Niger, Ghana and the Sudan all present interesting options

\subsection{2. 'The art of the possible': cost-effective, appropriate, sustainable} forest management

The forest resource in most parts of dry forest Africa is of low value in formal terms, but of high value to local people. The extent to which they are able to manage and will manage varies from area to area according a variety of criteria.

However, adaptation and simplification of the management of tropical dry forests to the human and financial resources likely to be available, to the products needed, and to the variability of the resource itself is long overdue. This research component will challenge existing management models and test alternatives. Findings may be appropriate to a broader spectrum of forests in due course 
Issues which need re-examination include:

- The relevance of European forest management models. If effective woodland management strategies are to be devised it is essential that woodlands are seen as products of their own particular ecological conditions. The diversity, variability and flexibility of the woodlands has been under-recognised and underresearched.

- The need to reduce the costs of woodland management by such methods as leaving the delineation of boundaries to customary authorities and representatives of local government; simplifying forest inventory and other forms of monitoring; accepting that enrichment planting will never be economic; leaving guarding and enforcement to local institutions with only those cases which cannot be resolved locally being dealt with at higher levels.

- Who will manage? The future of these forest areas is strongly dependent on the attitude, behaviour and practices of those who live there. However, this now falls to the retired, and to women, in many places. Male labour migration is increasingly long-term long-distance, is much more widespread - and removes those who would have managed in the past.

- What will they manage for? Dry forests are often primarily relied upon for fodder, fuel, small diameter poles and foodstuffs, rather than timber. How can management practices be adapted to fit these goals more effectively?

- How do you measure sustainability? Simpler resource monitoring and inventory methods are needed, which local people can understand and apply.

- How do you adapt management to the dynamic and variable nature of the forest?

- How do you change laws and policies to fit this reality? In spite of political decentralisation and institutional change, forest laws continue to back up the traditional mission of forest control and extraction. National level law ought to follow innovative attempts at forest management being tried on the ground.

- How can you cut the regulatory burden on poor people? Regulatory frameworks are often inconsistent with policy objectives, and vastly exceed the capacity available for compliance. This undermines the rule and legitimacy of law.

These topics will be investigated by

- Assembling and disseminating currently dispersed knowledge on low level management and monitoring by local people

- Deepening understanding of the policy and institutional framework which best supports such activities.

- Action research in case study sites to test sustainable and low-intensity ways of managing forest resources

- The presentation and debating of findings on new and more sustainable methods of managing at the Africa Forestry Commission, and through the Africa research networks CORAF, FORNESSA, AFORNET, etc. Beyond Africa, methods will be presented and debated at forest fora such as COFO, the CPF and IUFRO. 
Possible countries to be selected for this research area:

This topic feeds into topic 5, and it would be useful to select countries also selected for topic 1. However this topic dictates consideration not only of what rural people might be prepared to manage forest for, but also of the politico-legal context for that management. A selection of countries which offer insights into the most appropriate supportive arrangements for local management is thus needed (and which includes some unsupportive legal frameworks too). The countries suggested in topic 1 would make a good start. It would be interesting to have insights from countries with very different legal histories, such as Mozambique and - once it is possible to work there - Angola. Similarly 'difficult' West African example might also be selected, such as Nigeria.

\subsubsection{Major trends: dry forests and the future}

Africa is experiencing the fastest population growth rate in the world, and the fastest urbanisation rate in the world. Some parts are experiencing dramatic desiccation. HIV/AIDS and war are major features of the African scene. How will each of these affect the future relationship of forests, farmland, people and cities, and how should African countries be positioning themselves for successful adaptation?

- Assemble and disseminate information about Africa's predicted population growth, urbanisation rates, long-term food prospects, etc, against a background of possible rainfall decline.

- Conduct comparative investigations of the population growth and urban transition in Asia and Latin America, to tease out trends relevant to Africa.

- Assemble, synthesize and disseminate what is currently known about the impact on Africa's dry forests of wars, and refugee movements.

- Assemble, synthesize and disseminate what is currently known about the current and future likely impact on labour availability, gender roles and resource use/capacity to manage forests of Africa's HIV/AIDS pandemic.

- Assemble, synthesize and disseminate what is currently known about the likely results of current donor commitment to decentralisation and devolution for forests and local people.

- Compile a research report on likely changes for forests and the people dependent on them, include regrowth of unmanaged forest in some areas, but in general a tightening of land tenure and the disappearance of forest available to local people, unless the tenure of that too has been tightened in their favour.

- Present findings to country level fora including government officials and researchers and encourage brainstorming about likely future scenarios, and the measures which need to be planned, in that particular country to safeguard forests and people. 
Possible countries to be selected for this research area:

This topic requires the selection of countries whose dry forests have been impacted by war, refugee movements, HIV/AIDS, decentralisation, and population growth. Preliminary desk research will ultimately dictate the countries to be selected, but it is important that they are drawn from all three areas reviewed in this report - and that data exist or can be readily assembled. For that reason, a complete listing of possible countries cannot be given here. However, Sudan and Tanzania offer examples of dry forests impacted by war and refugee movements; Zambia, and Malawi's forests are clearly affected by HIV/AIDS; decentralisation, as this report shows, is happening in almost all the countries reviewed.

\subsubsection{Dry Forests and Climate Change: a dry run on how adaptation takes place in a climate change context}

In the Sahelian dry forests, adaptation to a transition to lower rainfall, in tandem with rising human populations, has been going on for almost twenty years. What lessons for future Climate Change adaptation can we learn from what has already taken place?

Rapid adaptability: During the 1990s in southern Niger, for example, farmers adapted to long-term rainfall decline, drought and high demographic growth while maintaining production and yields, increasing on-farm tree densities, and making other investments in land resources, transport and other off-farm income generating activities. Farming households adapted to climatic and demographic changes by introducing new seeding and cultivation methods, new crop varieties, and a wide range of soil fertility conservation measures. Where population densities are highest, intensification of agriculture is well under way, and there are strong economic linkages between rural farming areas and urban market economies. Where densities are lower, and adequate land resources still exist, farmers can still increase production through the extension of cropped areas.

Greater integration of land-use: Adaptation to climate change has forced much greater land-use integration upon local people, with the result that the land is now 'cultivated, grazed and harvested for forest products, all at the same time'.

Intensified management and privatisation of scarce resources: Where labour is sufficient, it has been invested in the maintenance of soil fertility (the management of manure and crop residues); in tree management on farms - the management and protection of natural regrowth in fallows - and to changed methods of livestock feeding. Animals may be fed on crop residues for nine months of the year, or may be sent south for part of the year. Fallowed land is now being privatised by its owners for animal feed. 
We know less about this process of livelihood change, in response to drought in other parts of dryland Africa, but the intensity of the Niger case suggests that it is time to investigate - in the miombo areas as well as in the Sahelian areas.

- In selected countries, gather existing data on adaptation to climate change using documents produced by projects and aid agencies, formal research and indigenous knowledge and experience. The Sahelian droughts of the 1970s and 1980s will yield important data, as well as more recent materials.

- In the same countries set in train research process for assembling new data on the subject, from government statistics, from field enquiry and from iterative field monitoring

- Establish links with CILSS, the UNCCD, and UNEP to share findings within Africa; with system-wide work on climate change within the CGIAR, and with the UNFCCC internationally.

- In country-level and international workshops debate the implications of the findings for the future management of dry forests, and for the role of farmers and land privatisation, and devise appropriate ways forward and future action.

Possible countries to be selected for this research area:

Ghana, Nigeria, Niger, Mali and Burkina Faso are all possibilities in West Africa; Sudan, Kenya (and perhaps Uganda - not reviewed here) in East Africa; Zimbabwe, Malawi, and Tanzania would make good Southern Africa cases.

\subsubsection{Collaborative forest management north and south of the equator}

Collaborative forest management/CBNRM has proceeded rather differently in the Sahel, and in miombo areas south of the equator. Is this the result of differing policies, assumptions, donor support and ideologies, or does the resource itself dictate different kinds of social organisation and economy and does this in turn support or detract from the possibilities for forest management with local people? This question has not been examined at all yet, but is clearly urgent before much more devolution of resources is attempted.

- In selected countries, gather existing data on collaborative management using documents produced by projects and aid agencies, formal research and indigenous knowledge and experience. In the same countries set in train a research process for assembling new data on the subject, from field enquiry.

- Establish links with a broad range of institutions, donors and research networks to share findings within Africa; with the CGIAR, and with the UNFF and CBD internationally.

- In country-level and international workshops debate the implications of the findings for the future management of dry forests, and for the role of farmers and villagers, and devise appropriate ways forward and future action. 
Possible countries to be selected for this research area:

For this topic, countries on which substantial research under topics 1 and 2 has taken place will need to be selected. For that reason, these three topic areas should be considered jointly when countries are selected. 


\section{SECTION 2. A FRAMEWORK FOR A DRY FORESTS' PROGRAMME}

This section provides the justification, framework and over-arching objectives for CIFOR's research on dry forests. While the focus is on Africa, many of the key themes are part of CIFOR's medium term plan and are also globally relevant; it is hoped that the research will also be implemented in dry forest areas on other continents, funding permitted.

\subsection{Why dry forests?}

\subsubsection{A brief spell in the international limelight}

Dry forests (defined in Box 2.1) constitute one of the major terrestrial ecosystems, existing in all developing regions of the world: Africa, Asia, and Latin America. Proportionately, they are most prominent in Africa, where drier forests in all their varieties - from the desert margin scrub to closed woodlands to deciduous forests bordering rainforest ecosystems - support the most people and livestock of all the continent's ecosystems.

\section{Box 2.1. What are 'dry forests'?}

In this document the term 'dry forest' is used in a very broad sense, covering the spectrum of vegetation types from deciduous forests with a continuous tree canopy (e.g. deciduous seasonal forest of Mexico and central America - Bullock et al., 1995), to tropical moist dystrophic savannas (e.g. miombo woodland - Campbell, 1996) and to dry eutrophic savannas (e.g. Sahelian wooded grassland, Kalahari thornveld - White 1983). Miombo woodland to the south of the equator in Africa covers some 270 million hectares. A major formation in South America is the Brazilian caatinga, covering nearly 100 million hectares (Bullock et al., 1995). There are also dry forests in non-tropical developing countries, of which 28 million ha are in highly populous China. The dry forests of developed countries, such as in the Mediterranean belt, are ignored due to our focus on low-income situations.

Dry forests arrived at centre stage of international co-operation during the West African "Sahelian" drought of the late 1970's to early 1980's when an abnormal succession of particularly dry years led to loss of much livestock, and perceived decimation of rangelands and savannas. The drought coincided with heightened concern over shortage of fuelwood ("the other energy crisis"). The combination of livelihood dislocation and ecological disaster attracted almost all donors to initiate major reforestation programmes - programmes that also provided Africa's first major testing ground for more participatory forestry. India's arid and semi-arid zones became another focus of donor-funded programmes.

By the mid-1980s, the enthusiasm started to wane; by the late 1980 s only a few donors persisted in supporting fuelwood projects and there was less interest in forestry generally. After the Earth Summit much donor attention and funding was 
centred on the rainforest systems. Research in dry forests had started to yield interesting and valuable insights, but with the shift in attention to other zones and sectors, many of these findings were not taken up. For instance, research in the Sahel showed how temporary protection of indigenous species in dry forests from browsing and other utilisation gave higher wood increment than planted woodlots, but such findings did not generally become the basis of a new round of projects.

\subsubsection{Dry forests in perspective}

It is useful to place the magnitude and contributions of the dry forests in quantitative perspective. Although estimates of forest cover vary, a broad indication of their significance is given in Table 2.1.

Table 2.1: Tropical forest type distribution in relation to population and deforestation - 1990.

\begin{tabular}{|c|c|c|c|c|c|c|c|c|c|c|}
\hline \multirow{2}{*}{\multicolumn{2}{|c|}{ Ecological zone }} & \multicolumn{2}{|c|}{$\begin{array}{l}\text { Area covered } \\
\text { by Eco-zone }\end{array}$} & \multirow{2}{*}{$\begin{array}{c}\begin{array}{c}\text { Population } \\
\text { density }\end{array} \\
\text { (persons/ } \\
\text { sq. km) }\end{array}$} & \multicolumn{2}{|c|}{$\begin{array}{c}\text { Total } \\
\text { population }\end{array}$} & \multicolumn{2}{|c|}{$\begin{array}{c}\text { Forest \& } \\
\text { woodland } \\
\text { area }\end{array}$} & \multicolumn{2}{|c|}{ Deforestation } \\
\hline & & $\begin{array}{c}\text { (mill. } \\
\text { ha) }\end{array}$ & $\%$ & & (mill.) & $\%$ & $\begin{array}{c}\text { (mill. } \\
\text { ha) }\end{array}$ & $\%$ & $\begin{array}{c}\text { (mill. } \\
\text { ha) }\end{array}$ & $\%$ \\
\hline \multicolumn{2}{|c|}{ Rainforest } & 947 & 19.8 & 41 & 388 & 15.6 & 718 & 76 & 4.6 & 0.6 \\
\hline \multirow[t]{3}{*}{$\begin{array}{l}\text { Dry } \\
\text { forest }\end{array}$} & $\begin{array}{c}\text { Moist } \\
\text { deciduous }\end{array}$ & 1289 & 27.0 & 55 & 709 & 28.5 & 587 & 46 & 6.1 & 0.9 \\
\hline & $\begin{array}{c}\text { Dry } \\
\text { deciduous }\end{array}$ & 706 & 14.8 & 106 & 748 & 30.1 & 179 & 25 & 1.8 & 0.9 \\
\hline & $\begin{array}{l}\text { Very dry } \\
\text { scrub }\end{array}$ & 543 & 11.4 & 24 & 130 & 5.2 & 60 & 11 & 0.3 & 0.5 \\
\hline \multicolumn{2}{|c|}{ Mountain forest } & 701 & 14.7 & 56 & 393 & 15.8 & 204 & 29 & 2.5 & 1.1 \\
\hline \multicolumn{2}{|c|}{ Other } & 592 & 12.4 & 15 & 89 & 3.6 & 8 & 1 & 0.1 & 0.9 \\
\hline \multicolumn{2}{|c|}{ Total } & 4778 & 100 & 52 & 2485 & 100 & 1756 & 37 & 15.4 & 0.8 \\
\hline
\end{tabular}

Source: Based on FAO (Mainly Forest Resources Assessment 1990). Unfortunately the recent FAO forestry assessment does not provide sufficiently detailed breakdown of deforestation by ecological type so we have used the older data. 'Dry forest' in our usage is covered by moist deciduous forest (e.g. miombo woodland), dry deciduous forest (e.g. Acaciaspp, Colophospermum mopane, Adansonia) and very dry scrub (e.g. shrublands of Acacia and Commiphora).

Table 2.1 shows that lands in the rainforest zone, which in the post-Rio period have attracted much donor attention, have about $20 \%$ of the land area in the tropics and this land has about $15 \%$ of the population in the tropics. By contrast, dry forest zones occupy about $54 \%$ of the land area of the tropics, this land area supporting about $64 \%$ of the population in the tropics. If much of the large population of China dependent on dry forests is taken into account (much in non-tropical zones), the importance of dry forests in developing countries becomes overwhelming. Furthermore, the last two columns show that together, a total of 8.2 million ha of dry forests are lost annually compared to 4.6 million ha of the rainforest system. The average deforestation rate in dry and moist deciduous forests is, at $0.9 \%$ annually, 
some $50 \%$ higher than in rainforests ${ }^{19}$. Livestock populations are also higher in dry forest zones than rainforest areas. It is clear that, proportionately, the drier forest ecosystems face far higher human and other development pressure than the moist forests. The importance of dry forests is also apparent in terms of specific countries: some populous countries are either dominated by or have extensive areas of dry forests, including China, India, Nigeria and Pakistan.

Dry forests, far more than rainforests, are central to food security. It is the dry forests (especially the moist deciduous forests - Table 2.1) that offer most of the potential agricultural expansion frontier and will therefore continue to be exposed to the greatest pressures. Dry forests offer protection for the water and soil resource base for agriculture; offer the bulk of dry-season fodder for vast livestock populations, without which this sub-sector would in some countries be unviable; provide fuelwood for domestic consumption (rural and urban) and rural-industry uses, including for drying major agricultural crops and fish; offer construction materials for farm structures and implements and homes for millions; are home to precious woods valued in handicraft industries; provide raw materials for packaging and wares used in homes and in harvesting farm produce; and are the source of commercially valuable non-timber forest products and a host of medicines for daily use by rural and urban populations.

The dry forests may not yield much commercial timber but their other life-support roles have vast importance. Furthermore, at a time when alternative economic opportunities remain under-developed, case studies show that up to a third of rural incomes in these areas may come from the forests.

Harold Mooney and colleagues write "degradation and conversion of dry forests is far more advanced than that of wet forests... they occupy more area than wet forests, have been of greater use to humans, and are still poorly known" (in Bullock et al., 1995).

\subsubsection{Compelling reasons for re-engagement}

If we adopt the spirit of the Earth Summit declarations, that people are the centre of development, the livelihood roles of dry forests offer compelling justifications for attention to be paid to these forests. Over a decade has now passed since many donors started to reduce forestry-related activities in dry forest regions. The time has come to reflect: Did everything in the Sahelian and Indian efforts really fail? Were the technologies that were attempted all bad? Were the social organisational efforts, which for the first time introduced people's participation on a significant scale, all inadequate or improperly executed? What are the pathways to poverty

\footnotetext{
${ }^{19}$ Rates of deforestation are notoriously unreliable, so little confidence can be placed on the actual numbers.
} 
alleviation in dry forest regions? The CIFOR research programme in dry forests needs to reflect on the past experiences, answer such questions and chart a way forward.

If we value the need for human-oriented development, should there not be renewed realisation that, no less than rainforests, dry forests must be managed sustainably for development? Taking what has been presented above, it becomes clear that dry forests deserve more attention simply because of their importance for people:

- They support far larger populations than rainforests;

- They are central to food security - they support more agriculture and are at the frontier of more agricultural expansion than rainforests. In particular, they are a direct source of food for livestock - one of the main sources of both capital and income in dry zones

- In some sub-regions, they are also the habitat for all the wildlife that attracts tourists. Such tourism is a major foreign exchange earner in the belt from Kenya to South Africa.

- They form a major component of livelihoods.

These and many other reasons explain a growing interest in re-engagement with dry forest issues. The issues have been particularly highlighted in recent years through dialogue under the auspices of the UN Convention to Combat Desertification, the post-UNCED UN initiative on countries with low forest cover (many of which fall in dry forest zones), and the CGIAR's "Desert Margins" programme.

This project document does not seek to give a full historical review of engagement with dry forests and its primary lessons - both positive and negative. A review document commissioned by CIFOR during the process of formulating this project ${ }^{20}$ is the vehicle for such detail as well as other in-depth consideration of dry forest issues. Suffice to say that many technologies and institutional arrangements have been tried out, usually inadequately. Disenchantment with the whole business led often to abandonment of the promising approaches alongside the bad and inadequate ones.

It is now time to look at what has changed in the dry forests over the last decade, to rediscover what was promising, and to build upon it for enhancing the benefits of dry forests to poor people and economies in dry forest countries. From the recent review, it is clear that problems of management remain acute (Section 1).

\footnotetext{
${ }^{20}$ Shepherd, Gill, 2002. Africa's tropical dry forests - time to re-engage. An agenda for priority research. Review report commissioned by the Center for International Forestry Research (CIFOR). Overseas Development Institute. London.
} 


\subsubsection{Lessons to build upon}

There have been important changes during the post-Sahelian period, which make a rethink necessary. Firstly, forests have had a considerable degree of attention since the Rio Earth Summit, through the processes of the Intergovernmental Panel on Forests (IPF), Intergovernmental Forum on Forests (IFF) and now United Nations Forum on Forests (UNFF). Secondly, many countries have redrafted their forest policies over the last decade, to include in many cases greater devolution of forest management to local people - alone or in collaborative arrangements with government. This greater sharing of management responsibilities has taken place much faster and much more readily in countries where the export timber value of forests is low - i.e. in dry forests. Dryland Africa has been part of this story.

Africa in particular is experiencing the fastest rates of population growth in the world, and very dynamic changes are occurring in rural areas that are imposing additional pressures on natural resources. However, like much of development in Africa (as elsewhere), funding constraints have led to a belief that what little is available must go to "action" - leaving aside the essential process of systematic learning and adaptive management. Research has been ignored as a luxury; and the drawing of lessons from experience has been minimal. Clearly, the time has come to pay greater systematic attention to knowledge - not only of what works but also why it works and under what circumstances. The research proposed here is directed at initiating this process - with realism dictating that attention first go to a few countries.

\subsubsection{Areas of promise}

Before beneficiaries themselves became disillusioned and donors also lost patience, the Sahelian period yielded a number of promising approaches that were not given adequate chance or time to prove themselves:

- The protection of naturally regenerating dry forest as a way of competing successfully with expensive and inadequate woodlots

- Site-preparation techniques that slowed down water-loss rates reducing mortality during droughts;

- Awareness that pastoral populations engaged in transhumance are important stakeholders in management of dry forest vegetation. There was less success in learning how best to engage them;

- Management of natural dry forests for fuelwood, linked to community-controlled fuelwood markets;

- Popularisation of participatory approaches to resource management.

One should also not ignore the important gains in heightened awareness of the importance of traditional knowledge revealed in a multitude of uses for plants and in selective retention of certain species in natural parklands; heightened attention to 
forest issues; and increased profile of forests and forestry in national development agendas - for a time at least. In the Sahel, sustainable management of dry forests came to achieve central place in National Environmental Action Plans and in strategies to combat desertification.

Some of these and other promising areas of success or near-breakthrough deserve a second look, further screening, and refinement. Not only has development practice in other sectors - particularly with regard to people's participation and indigenous knowledge - moved on, but the forest/ livestock/farmland dynamic has changed considerably in recent years.

\subsection{Goals}

\subsubsection{Development goal}

The overall development goal is to enhance the social and economic development of Africa. Africa, as the poorest continent, has the greatest dependence on natural resources of any continent, and its forests play a more important livelihood role than in any other continent.

\subsubsection{Research goal}

The research goal is to strengthen the scientific and other analytical base necessary so that dry forests can play an effective and sustainable part in contributing to economic and social development.

These goals will be met through five specific areas of focus. In the focus areas a number of possible activities have been identified (Annex 2.1), largely from the research prioritisation exercise carried out in Yaounde (Annex 2.2; CIFOR 2001). These are too many activities listed in Annex 2.1 for the size of programme envisaged, but we list them here so as to capture the discussions that we have had, and as a basket of possibilities in an adaptive dry forest programme. The five focus areas are as follows (expanded in the next sub-section).

- Understanding contributions of dry forests to local livelihoods and national economies and determining pathways to poverty alleviation (Topic 1).

- "The art of the possible" - tailoring sustainable management approaches for dry forests to the social, economic and technological capacities in Africa. (Topic 2).

- Major trends - understanding key extra-sectoral determinants relevant to crafting policies and sustainable-management approaches for dry forests (Topic 3).

- Anticipating climate change - the Sahelian drought as Africa's "dry run" on socioecological resilience and adaptation in the dry forest zone (Topic 4).

- Collaborative forest management north and south of the equator (Topic 5). 
The proposed research will be multi-faceted and multi-disciplinary. It will look at biophysical, socio-cultural, policy, and institutional factors that determine sustainable dry forest management. It will interpret sustainable management to include utilisation, both subsistence and commercialised. For each activity, a preliminary review of what is already known will be conducted, bearing in mind the particularities of working in Africa. Information will reside at least as much in the documents produced by development projects and aid agencies as in formal research. Indigenous knowledge will be a key resource for several of the Topics.

The research will also have three supporting elements: (a) contribution to capacity building, especially for postgraduate/postdoctoral interns, visiting fellows and promising early-career professionals from the region; (b) on-going communication and dissemination of findings, forged on the basis of close collaboration with clients and stakeholders; (c) particular attention to influencing policy through policy products and the convening of appropriate discussion and dissemination fora.

\subsection{What research is proposed - the five focus topics}

Experience suggests that earlier attempts to engage with dry forests failed firstly to give sufficient credit to their embeddedness within livelihoods, and selected onedimensional solutions (e.g. woodlots for fuelwood) on the analogy of forest management in the wealthier countries of the North, where populations are largely urban rather than largely rural. Secondly, 'technical fix' solutions were sought in a context where social, institutional and political issues were at least as important as the biological ones. Thirdly, a number of the presenting problems (e.g. 'the fuelwood crisis'; 'advancing deserts') were based on misdiagnosis, and only as a broader approach to dry forests become possible, do other issues present themselves as important.

Focus areas have been selected that apply to dry forest zones throughout Africa and that are globally important. We reflect this by reference to CIFOR's medium term plan for research, which is based on global priorities. Thus the research programme will be in a position to draw on knowledge emerging in developing countries from other continents and will provide insights for development practitioners in these other regions. CIFOR's global mandate provides an excellent opportunity for dry forest work to contribute to the broader global research on forests, and for dry forest results to add additional points on the continuum from very dry to rainforest regions.

TOPIC 1: Dry forests and trees - understanding contributions to local livelihoods and national economies, and charting the direction for poverty alleviation.

The Forest Products and People (FPP) program of CIFOR has an intermediate goal of contributing to poverty alleviation, food security and environmental protection 
through improved management, use, processing and trade of non-timber forest products, while the Forests, Society and Policy (FSP) program has the intermediate goal of facilitating the formulation and implementation of policies and practices that reduce inappropriate deforestation and forest degradation and improve people's well-being.

In dry Africa, above all, dry forests offer a substantial part of the livelihood of large numbers of people. Less recognised is the fact that although they produce little commercial timber, dry forests play a fundamental part in national economies (e.g. by supplying energy for drying key export crops, by providing feed for commercially important livestock), apart from providing numerous intangible and non-marketed values.

One of the objectives under this Topic will be to understand the role of forest products in the dynamic social and economic systems that occur in dry forest regions $^{21}$. Given understanding of livelihoods, the aim is to pinpoint the areas where development, particularly forest-based development, can play a role in poverty alleviation. We also plan to understand possible trade-offs between maintaining natural forest cover and improving the well-being of people in forested areas. As much development is not forest-based, the crucial subsistence and safety-net values of forests to poor, forest-based communities will be identified, so that these values of dry forests are protected, where appropriate. Non-timber forest products and systems with high potential to contribute to income and employment will be identified so that they can be effectively targeted by donors, development agencies and government interventions.

One component of this Topic will be, for 3 or 4 selected African countries, to make as full a calculation as possible of the multiple values of dry forests to local livelihoods and national economies. Methodologies for assessing the full contributions to local livelihoods that dry forests make, and of scaling up to national level the contributions that dry forests make to local livelihoods, have yet to be perfected and mainstreamed. A perverse result is, for example, that governments are willing to give high priority to tourism but not to the dry forest habitat that makes tourism possible; high priority to cultivation of tea and tobacco but little to the forest that supplies the fuelwood and other wood inputs to their preparation; high attention to hydroelectricity, while not caring for vegetation that ensures low soil erosion into the dams etc. For governments to give the dry forests the attention they deserve, these contributions need to be teased out and highlighted to policy makers through development of appropriate methodologies. As part of the research the role of such valuation will be assessed - through documenting the policy processes that such valuations may or may not stimulate.

\footnotetext{
${ }^{21}$ Many of the issues covered in this paragraph are captured in the FPP programme medium term plan; understanding trade-offs between development that results in deforestation and changes in welfare is part of the FSP programme.
} 
TOPIC 2: "The art of the possible" - tailoring sustainable management approaches for dry forests to the social, economic and technological capacities in Africa.

The intermediate goal of the Adaptive Collaborative Management of Forests (ACM) programme is to achieve more sustainable and equitable management of forest resources and human well-being in a multi-stakeholder environment, while the intermediate goal of the Sustainable Forest Management (SFM) programme is to improve the management of natural tropical forests by increasing the adoption of sustainable forest management practices by forest managers from industries to communities. These goals form the thrust of Topic 2.

Africa is strapped for funds and for human and institutional capacities to implement sustainable forest management under the elaborate formal approaches developed in Europe and imported wholesale in the past. In any case, the forest resource in dry Africa generates only modest cash income, if any, but has high life-support values to local people. Such dry forests generate too little revenue to pay for elaborate and complex management regimes. Africa faces enough problems in carrying out fullyelaborate management of commercial forests and is clearly rarely in a position to manage low-value forests that generate little revenue in a complicated way. It is necessary to become realistic in expectations of what kind of management the continent can afford in terms of funding but also of its skills and institutional capacities.

The post-colonial period has witnessed structured procedures of forest management including elaborate working plans that fall by the wayside under pressure from tight budgets and staff shortages. Recent international pressures to introduce fully elaborated "criteria and indicators" of sustainable forest management have also failed to take root - they are over-elaborate for the implementation capacities. The formalisation of design principles (sensu Ostrom) for common property systems is likely to involve high transaction costs that cannot be sustained by the resource benefits. Economic structural adjustments have weakened capacities further and medium-term prospects show little likelihood that Africa can mainstream elaborate modern management regimes unless they are adapted and simplified to focus on only the most critical requirements.

Management techniques (biophysical) as well as policy and organisational requirements (socio-economic) for the largely non-commercial tropical dry forests must be scrutinised. If they are to be applied, they must match the human and financial resources likely to be realistically available, the low monetary value of the resource itself and its variability, and the products needed. Adaptation and simplification of the management of tropical dry forests to the capacities of Africa is long overdue. There is need to focus on only the most important elements and the most affordable technologies and organisational formats, the cost of which can be accommodated 
within an environment of low revenue from the forests. Africa is not well served by setting itself idealistic procedures which it has no chance of satisfying.

This research component will challenge existing technologies (as detailed in Bellefonte et al., 1997) as well as management and organisational models, not because they cannot work but because many are unaffordable and unfeasible in Africa's present circumstances; it will test or initiate testing of alternatives. Research should seek to answer:

- What natural forest management practices are appropriate to dry forests?

- What are the barriers to adoption of sustainable forest management practices? (What are the costs and benefits of sustainable forest management, to whom do they accrue and what are the trade-offs among different practices?)

- What approaches and tools can be used to encourage sustainable use and management of forest resources?

- What is the feasibility of preventing degradation of dry forests over a range of biophysical and socio-economic conditions in Africa? Is it possible to actively promote rehabilitation, and in what contexts will such a strategy be successful?

TOPIC 3: Major trends - understanding key extra-sectoral determinants relevant to crafting policies and sustainable-management approaches for dry forests.

Africa reveals numerous rapid changes in livelihood, with changes in the peopleforest interaction: sedenterisation of pastoral communities; massive rise in HIV/AIDS mortalities with likely impacts on labour availability, gender roles and resource use; agricultural intensification and livelihood diversification; economic liberalization and globalisation; commodity market fluctuations; changing urban demands for agricultural products. Africa has the fastest population growth rates in the world and among the fastest urbanisation rates. War is major features of the African scene. Decentralisation policies are sweeping the continent, with consequent changes in tenure. Also, the continuing poverty will fundamentally define the nature and severity of pressure on dry forests. Despite slow economic growth, Africa is facing rapid monetisation of rural economies and is increasingly touched by globalisation. What are the key changes in rural society and how do they affect dry forest use and management? This forward-looking research component will consider questions such as: How will each of these factors affect the future relationship of forests, farmland, people and cities, and how should African countries be positioning themselves for successful adaptation? What responses can work as these changes take root?

This research Topic will be closely related to that of Topic 1 and will largely address the concerns expressed in the medium term plan of the Forests, Society and Policy (FSP) program of CIFOR. In particular this research will aim to guide policy-makers, 
decision-makers and opinion leaders and increase their capacity to: understand how factors outside the forest sector can affect forest condition and the well-being of people in forested areas. The work will build on the current studies of extrasectoral influences on dry forests and decentralization (Nhantumbo and Kowero, 2001; Campbell and Shackleton, 2001), with the emphasis being on taking the emerging results into the policy process.

\section{TOPIC 4: Anticipating climate change - the Sahelian drought as Africa's "dry run" on socio-ecological resilience and adaptation in the dry forest zone.}

Following the unprecedented Sahelian drought, during which climate change was faster and more severe than future expectations predicted by global models, the dry forests have for almost twenty years been undergoing adaptation to lower rainfall, in tandem with rising pressure from growing human populations. What lessons for future climate change adaptation can we learn from what has already taken place? This component of research will look at technologies as well as policy, socio-economic and institutional adjustments. In parts of the West African Sahel, there is evidence of considerable ecosystem resilience; rapid adaptability of institutions and lifestyles; greater integration of land-uses; more intensified management and privatisation of scarce resources; and changing role for dry forests in rural livelihoods. For other parts of dryland Africa, we know less about the above processes of livelihood change in response to drought and the proposed research is intended to correct this.

Being focussed on dynamic livelihoods, this Topic overlaps with Topic 1 and 3 but centers on climate as the agent of change. Climate change is possibly the greatest long-term environmental threat to sustainable forest management, biodiversity and local livelihoods in the tropics. The work will address the CIFOR medium term objectives of guiding policy-makers, decision-makers and opinion leaders and increasing their capacity to understand how factors outside the forest sector can affect forest condition and the well-being of people in forested areas (FSP programme) and how forest use changes in highly dynamic socio-economic and biophysical settings (FPP programme).

\section{TOPIC 5: Collaborative forest management north and south of the equator}

Collaborative forest management/CBNRM has proceeded rather differently in the Sahel, and in miombo areas south of the equator. Is this the result of differing policies, assumptions, donor support and ideologies, or does the resource itself dictate different kinds of social organisation and economy and does this in turn support or detract from the possibilities for forest management with local people? This question has not been examined at all yet, but is clearly urgent before much more devolution of resources is attempted.

This topic is centre stage within the ACM programme of CIFOR. 


\subsection{Country choices}

It is proposed that research effort be concentrated on a few selected countries, although case studies on specific themes can cover other countries outside the focus list. CIFOR recommends, however, that case studies be arranged to cover countries on the spectrum from those with abnormally high success in retaining or increasing forest cover to those where deforestation is very high (FAO 2000). In the process of selecting specific study sites, CIFOR will seek to select a representative sample of different types of forest, different types of adjacent land-use, different stages of devolution, and different degrees of human pressure and capacity to manage forests (Annex 2.3).

Suggested countries for the initial phase effort are: Burkina Faso, Malawi, Zambia, Mozambique and Tanzania. In southern Africa, Mozambique and Tanzania are the two countries coming closest to being middle-ground in terms of resource history and resource pressure. However, they contrast in that Mozambique has the weakest human resources for management while Tanzania has some of the strongest. Malawi is a country with high deforestation because of high rural population densities. Zambia has among Africa's highest urban: rural population ratio, with vast areas of dry forests.

Mali, Niger and Burkina Faso are possible candidate countries in West Africa, traversing the full spectrum of dry forest systems from the Sahara to dense woodland vegetation. Among them, they have almost the full range of dry forest resource endowment and socio-economic variation that exists in the Sahel. Of the Anglophone west African countries, northern Ghana is abnormally densely settled and has little residual forest; northern Nigeria is a complex case for which a final decision is best explored at work-planning stage. There is a likelihood that many of the issues it faces can be well captured in Niger across the border.

Eastern Africa could also yield valuable lessons. The Sudan is much the most interesting country for study, but both it and the dry north of Uganda may be difficult to work in for military reasons. Ethiopia has a long history of international co-operation, but its land tenure situation offers little protection for natural forests, and makes it very atypical by the standards of the rest of Africa. Kenya is well-known more for its successful on-farm tree-planting than for its management of dry forests. It has steadfastly refused to allow any devolution of forest management to local people

\subsection{Activities, sub-activities and milestones}

For ease of tracking, the activities and sub-activities falling under each Topic have been tabulated (Annex 2.1). As stated earlier, the activities listed in the Annex are too many for the size of programme envisaged, but represent a basket of possibilities in an adaptive dry forest programme. 


\subsection{Institutional arrangements for project implementation}

The project will be designed to last four years in its current first phase. Given the long-term nature of forest-related processes, continuation beyond that but at a different scale is envisaged. Such extension will be subject to formal evaluation of the project.

CIFOR will serve as implementing agency and will manage the funds, including responsibility for reporting on technical and financial matters. CIFOR headquarters in Bogor, Indonesia will serve as formal focal point for the project but implementation will largely be delegated to its sub-regional Office located in Harare, Zimbabwe.

CIFOR plans to be guided by certain considerations as it implements the activities, as set out in Box 2.2. We envisage promoting change through policy dialogue. All research Topics would have a policy component, with the intention of understanding the nature of gaps in the policy dialogue continuum, how to bridge them, and how to best inform policy formulation, once we have the research data with which to promote change. All research Topics will generate policy briefs and discussion in policy fora. CIFOR will document the nature of the policy formation process; general lessons for policy research will be drawn and disseminated to policy research organisations. 
Box 2.2: Guiding intentions for CIFOR in undertaking dry forests research

Adding value:

CIFOR will work through partnership and will play a direct part where national institutions need its external perspective. Greatest efforts will be made to use local institutions and expertise but in institutions ranging from universities, NGOs and private sector rather than only government.

CIFOR will establish close working relationships with ongoing development projects and with repositories of historical information (such as Ministries of Forestry and local offices of key donors) on earlier dry forest management interventions.

CIFOR will similarly associate with major international repositories of such information in partner donor countries and main international organisations especially FAO, World Bank, and African Development Bank.

\section{Scope of research:}

CIFOR will generally include attention to the following elements in its research, which will fuse the biophysical and the socio-economic:

- Assembling and disseminating currently dispersed knowledge (modern approaches; traditional but evolving approaches; approaches from outside the region);

- Improving on the most promising technologies;

- Deepening understanding of social and institutional factors supporting successful resource management;

- Capturing fast-eroding indigenous knowledge of management and use of dry forests;

- Attention to policy making processes;

- Capacity building and networking

Awareness of change:

Given the rapid changes in Africa, CIFOR will complement any historical analysis with a forward-looking orientation, with recommendations to reflect likely changes in society.

Context of recommendations:

CIFOR will endeavour to give recommendations in context of enabling conditions that would affect their adoption.

There are numerous stakeholders involved in research and development in dry forest systems, and many involved in the management of dry forests. If this research is to have the desired impact, then CIFOR will need to form appropriate collaborative mechanisms with the various partners. For example, Topic 2 described above (tailoring sustainable management approaches of Africa's dry forests to its social, economic and technological capacities) will also be a priority for CIRAD-Foret in Mali. 
Collaboration with ILRI will be essential to cover livestock issues in dry forests. Similarly, it will be important to engage ICRISAT, ICRAF and IFPRI. Similarly, CIFOR will need to convene inputs from its developing country partners.

\subsection{Indicative budget}

We envisage a programme in the order of US $\$ 1.5$ million - US $\$ 2.0$ million over a 4year period (2002-2005), with an indicative budget as given in Table 2.2.

Table 2.2: Indicative budget

\begin{tabular}{|c|c|c|c|c|c|c|}
\hline \multirow[t]{2}{*}{ Cost item } & \multicolumn{6}{|c|}{ Cost, by year (US\$ '000) } \\
\hline & 2001 & 2002 & 2003 & 2004 & 2005 & TOTAL \\
\hline \multicolumn{7}{|l|}{ SWEDEN } \\
\hline Preparatory phase & 30 & - & & & & 30 \\
\hline $\begin{array}{l}\text { Seconded Swedish } \\
\text { expert }\end{array}$ & 37 & 68 & 67 & 85 & 85 & 342 \\
\hline Internships (two) & - & 30 & 28 & 30 & 30 & 118 \\
\hline $\begin{array}{l}\text { Research } \\
\text { implementation } \\
\text { phase }\end{array}$ & - & 120 & 150 & 150 & 180 & 600 \\
\hline SWEDEN Sub-total & 67 & 218 & 245 & 265 & 295 & 1090 \\
\hline \multicolumn{7}{|l|}{ OTHER DONORS } \\
\hline $\begin{array}{l}\text { OTHER DONORS } \\
\text { Sub-total }\end{array}$ & - & 166 & 276 & 242 & 227 & 911 \\
\hline GRAND TOTAL & 67 & 384 & 521 & 507 & 522 & 2001 \\
\hline
\end{tabular}

\subsection{Main references}

Bellefontaine, R., Gaston, A. \& Petrucci, Y. 1997. Aménagement des Forêts naturelles des zones tropicales séches. Cahier FAO Conservation No. 32. FAO, Rome.

Bullock, S.H., Mooney, H.A., Medina, E. (eds). 1955. Seasonally dry tropical forests. Cambridge University press, U.K.

Campbell, B.M. (ed.) 1996. Woodlands and welfare: the miombo woodlands in transition. Centre for International Forestry Research, Bogor. 266 pp.

Campbell, B.M. \& Shackleton, S. 2001. The organizational structures for community-based natural resource management in Southern Africa. African Studies Quarterly 5, no.3: [online] URL: http://web.africa.ufl.edu/asq/v5/ v5i3a6.htm 
CIFOR. 2001. Forestry research in Sub-Saharan Africa: review of priorities. Report of the partners meeting on a strategy for the activities of CIFOR in Sub Saharan Africa. CIFOR Regional Office for Humid Central and West Africa, 20 - 23 February 2001. Humid Forest Ecoregional Centre, IITA. Nkolbisson, Yaounde, Cameroon.

CIFOR. 2002. Stimulating policy dialogue on sustainable management of Africa's dry forests. Summary Proposal to Sida for a Dry Forest Programme. Center for International Forestry Research.

Dewees, P.A. 1994. Social and economic aspects of Miombo woodland management in Southern Africa: options and opportunities for research. CIFOR occasional paper no. 2. CIFOR. Bogor.

FAO. 2001. Global Forest Resources Assessment 2000: Main report. FAO Forestry Paper No. 140. FAO, Rome.

Nhantumbo, I. and Kowero, G. 2001. A goal programming model for planning management of miombo woodlands. CIFOR occasional paper no. 35. CIFOR. Bogor.

Shepherd, G.. 2002. Africa's tropical dry forests - time to re-engage. An agenda for priority research. Review report commissioned by the Center for International Forestry Research (CIFOR). Overseas Development Institute. London.

Shepherd, G. 1992. Managing Africa's tropical dry forests - a review of indigenous methods. Overseas Development Institute. London. ISBN 0-85003-139-7

White, F. 1983. The vegetation of Africa. Unesco, Switzerland.

Wily, E. and Dewees, P. 2001. From Users to Custodians: Changing Relations between People and the State in Forest Management in Tanzania. World Bank Working Paper. http://econ.worldbank.org/view.php?type=5\&id=1617 
SECTION 3. STIMULATING POLICY DIALOGUE ON SUSTAINABLE MANAGEMENT OF AFRICA'S DRY FORESTS - PROPOSAL TO SIDA FOR A DRY FOREST PROGRAMME

\subsection{Background to this document}

After an extensive prioritisation exercise, five themes and numerous activities were selected for consideration in a Dry Forest Programme (Section 2). This Section summarises the sub-set of themes and activities that will be tackled in a programme of policy dialogue.

\subsection{Why dry forests?}

"Degradation and conversion of dry forests is far more advanced than that of wet forests... they occupy more area than wet forests, have been of greater use to humans, and are still poorly known" (Harold Mooney and colleagues, in Bullock et al., 1995).

Extensive justification for more attention to be paid to dry forests has been given in the Sections 1 and 2. Dry forests constitute one of the major terrestrial ecosystems, existing in all developing regions of the world: Africa, Asia, and Latin America. Proportionately, they are most prominent in Africa, where drier forests in all their varieties - from the desert margin scrub to closed woodlands to deciduous forests - support the most people and livestock of all the continent's ecosystems.

\subsection{The main thrusts of the activities}

\subsubsection{Building on current knowledge}

There is much scattered research and information on dry forests. While there are some important new areas requiring empirical research (e.g. HIV/AIDS impacts on rural livelihoods; climate change implications; forest management in an era of decentralisation) and some promising technological interventions that require further investigation, much of the research effort is to compile and synthesise information from the grey literature (donor reports; project evaluation reports; theses in numerous universities in the region).

\subsubsection{Getting information out to the users}

While journal articles may contain rigorously-reviewed results, the information they contain is inaccessible to all but the specialists in the subject matter. On the other hand, the grey literature is of notoriously mixed quality. In CIFOR's dry forest work, 
we propose to produce journal and other peer-reviewed science publications, but to also convert the science into material relevant to the various stakeholder groups. This will be a first step in engaging in the policy process.

\subsubsection{Stimulating policy dialogue}

The transfer of technology model for science (e.g. where researchers produce results for extension workers who pass the results onto farmers) has been seriously questioned in many contexts. An emerging model for science for many situations is that of close and constant interaction with the clients. This is the model we intend to follow, with a range of stakeholder groups. We will pay particular attention to influencing policy through policy products and the convening of appropriate discussion and dissemination forums. In Annex 3.1 we indicate some of the stakeholder groups we will engage.

\subsubsection{Integrated approaches}

The proposed work will be multi-faceted and inter-disciplinary. It will look at biophysical, socio-cultural, policy, and institutional factors that determine sustainable dry forest management.

\subsubsection{Commitment to capacity building}

The work will contribute to capacity building, especially for postgraduatel postdoctoral interns, visiting fellows and promising early-career professionals from the region.

\subsection{Goals and objectives}

\subsubsection{Development goals}

(a) The overall development goal is to enhance the social and economic development of Africa. Africa, as the poorest continent, has the greatest dependence on natural resources of any continent, and its forests play a more important livelihood role than in any other continent.

(b) A subsidiary goal is to strengthen the scientific and other analytical base necessary so that dry forests can play an effective and sustainable part in contributing to economic and social development. 


\subsubsection{Research objectives}

There are three main research objectives:

1. To understand contributions of dry forests to local livelihoods and national economies and to determine pathways to poverty alleviation.

2. To tailor sustainable management approaches for dry forests to the social, economic and technological capacities in Africa.

3. To understand key extra-sectoral determinants relevant to crafting policies and sustainable-management approaches for dry forests.

Greater detail for each of these objectives is given in the framework proposal (see Section 2 where these objectives are referred to as Topic 1, 2 and 3).

\subsection{Activities}

The research activities identified in this Section (Table 3.1) assume the level of funding for "research implementation phase" in Table 3.2.

Table 3.1. Research activities, milestones and timing of products.

\begin{tabular}{|c|c|c|c|c|}
\hline \multirow{2}{*}{ Activities } & \multirow{2}{*}{ Milestones } & \multicolumn{3}{|c|}{ Timing of product } \\
\hline & & 2003 & 2004 & 2005 \\
\hline \multicolumn{5}{|c|}{$\begin{array}{l}\text { 1. Activities for objective 1: Understanding contributions of dry forests to local } \\
\text { livelihoods and national economies, and determining pathways to poverty alleviation }\end{array}$} \\
\hline \multirow{4}{*}{$\begin{array}{l}1.1 \text { Reviewing and } \\
\text { assessing the } \\
\text { contribution of dry } \\
\text { forests to livelihoods } \\
\text { and national economies }\end{array}$} & $\begin{array}{l}\text { 1.1.1 Case studies for at least two countries: } \\
\text { two technical reports on local livelihoods } \\
\text { and life-support contributions of dry } \\
\text { forests and trees. }\end{array}$ & $x$ & $x$ & \\
\hline & $\begin{array}{l}\text { 1.1.2 Summary popular report on national } \\
\text { significance of contributions for at least } \\
\text { two countries - input to } 4.2\end{array}$ & $x$ & $x$ & \\
\hline & $\begin{array}{l}\text { 1.1.3 Policy brief for regional economic } \\
\text { forum on significance of dry forests - input } \\
\text { to } 4.4 \text { (also } 4.2 \& 4.3 \text { ) }\end{array}$ & & $x$ & $x$ \\
\hline & $\begin{array}{l}\text { 1.1.4 Policy brief on small-scale forest- } \\
\text { based enterprises with mainstream } \\
\text { potential as African economies grow - to } \\
\text { serve as input to } 1.3\end{array}$ & & & $x$ \\
\hline \multirow{2}{*}{$\begin{array}{l}1.2 \text { Identification of } \\
\text { pathways to poverty } \\
\text { alleviation in dry } \\
\text { forest regions }\end{array}$} & $\begin{array}{l}\text { 1.2.1 Report on policy alleviation pathways in } \\
\text { dryland Africa - input to } 1.2 .2 \text {. }\end{array}$ & & $x$ & \\
\hline & $\begin{array}{l}\text { 1.2.2 Think tank of livelihood specialists } \\
\text { convened on "poverty alleviation" in dry } \\
\text { forest regions and draft policy brief } \\
\text { produced }\end{array}$ & & $x$ & \\
\hline
\end{tabular}




\begin{tabular}{|c|c|c|c|c|}
\hline & $\begin{array}{l}\text { 1.2.3 Policy brief for donor organisations: } \\
\text { role and direction of development in dryland } \\
\text { Africa in terms of poverty alleviation } \\
\text { potential - input to } 4.5 \text { (also } 4.2-4.4 \text { ) }\end{array}$ & & $x$ & $x$ \\
\hline $\begin{array}{l}1.3 \text { Convene a policy } \\
\text { forum of organisations } \\
\text { promoting small- } \\
\text { business development, } \\
\text { extension officers, and } \\
\text { NGOs to explore } \\
\text { income opportunities } \\
\text { based on dry forest } \\
\text { and tree activities. }\end{array}$ & 1.3.1 Workshop report & & & $x$ \\
\hline \multicolumn{5}{|c|}{$\begin{array}{l}\text { 2. Activities for objective 2: Tailoring sustainable management approaches for dry } \\
\text { forests to the social, economic and technological capacities in Africa }\end{array}$} \\
\hline \multirow{3}{*}{$\begin{array}{l}\text { 2.1 Deepening the } \\
\text { overall understanding } \\
\text { of the main factors } \\
\text { supporting successful } \\
\text { dry forest } \\
\text { management }\end{array}$} & $\begin{array}{l}\text { 2.1.1 Report on elements of effective and } \\
\text { sustained community participation in } \\
\text { management of dry forests }\end{array}$ & $x$ & & \\
\hline & $\begin{array}{l}\text { 2.1.2 Paper on barriers to adoption of } \\
\text { sustainable forest management practices }\end{array}$ & & $\mathrm{X}$ & \\
\hline & $\begin{array}{l}\text { 2.1.3 Synthesis semi-popular report on } \\
\text { determinants of success and failure in dry } \\
\text { forests management, illustrated by case } \\
\text { studies - input to } 4.2 \& 4.5\end{array}$ & & & $\mathrm{X}$ \\
\hline \multirow{3}{*}{$\begin{array}{l}2.2 \text { Critically evaluate } \\
\text { silvicultural practices } \\
\text { to enhance } \\
\text { sustainability and } \\
\text { value of forest goods } \\
\text { and services at all } \\
\text { scales in low-capacity } \\
\text { environments. }\end{array}$} & $\begin{array}{l}\text { 2.2.1 Assemble and analyse currently } \\
\text { dispersed knowledge on silvicultural options } \\
\text { for managing and rehabilitating dry forests } \\
\text { for the main products and services required }\end{array}$ & $x$ & & \\
\hline & $\begin{array}{l}\text { 2.2.2 Popular publication on the top three } \\
\text { technological developments with most } \\
\text { promise to improve dry forest management - } \\
\text { input to } 4.2 \& 4.5\end{array}$ & & $x$ & \\
\hline & $\begin{array}{l}\text { 2.2.3 Popular leaflet "A manageable brand of } \\
\text { dry forest management in dry Africa" - } \\
\text { input to } 4.2 \& 4.5\end{array}$ & & $x$ & \\
\hline \multirow{2}{*}{$\begin{array}{l}2.3 \text { Adapting } \\
\text { application of } \\
\text { international criteria } \\
\text { and indicators (C\&I) } \\
\text { of sustainable forest } \\
\text { management to dry } \\
\text { African reality. }\end{array}$} & $\begin{array}{l}\text { 2.3.1 A technica/review report with } \\
\text { illustrative cases on key criteria and } \\
\text { indicators - input to } 2.4\end{array}$ & $x$ & & \\
\hline & $\begin{array}{l}\text { 2.3.2 A popular everyman's guide to C\&I in } \\
\text { dry forests - input to } 2.4,4.2 \& 4.5\end{array}$ & & $x$ & \\
\hline $\begin{array}{l}2.4 \text { Organise } \\
\text { specialised forum of } \\
\text { officials and } \\
\text { international partners } \\
\text { to discuss what C\&I } \\
\text { framework is realistic } \\
\text { for Africa's dry } \\
\text { forests. }\end{array}$ & 2.4.1 Workshop report & & $x$ & \\
\hline
\end{tabular}




\begin{tabular}{|c|c|c|c|c|}
\hline \multicolumn{5}{|c|}{$\begin{array}{l}\text { 3. Activities for objective 3: Understanding key extra-sectoral determinants relevant to } \\
\text { crafting policies and sustainable-management approaches for dry forests. }\end{array}$} \\
\hline \multirow{4}{*}{$\begin{array}{l}3.1 \text { Assemble, analyse } \\
\text { and disseminate } \\
\text { information about } \\
\text { implications for dry } \\
\text { forest cover of major } \\
\text { developments in } \\
\text { Africa's dry forest } \\
\text { regions }\end{array}$} & $\begin{array}{l}\text { 3.1.1 Semi-popular presentation of latest } \\
\text { situation and future prospects given } \\
\text { projections of driving forces - input to } 4.2 \text {, } \\
4.3,4.4 \& 4.5 \text {. }\end{array}$ & $x$ & & \\
\hline & $\begin{array}{l}\text { 3.1.2 In-depth technical reports on two most } \\
\text { important external underlying threats to dry } \\
\text { forests. }\end{array}$ & $\mathrm{x}$ & & $x$ \\
\hline & $\begin{array}{l}\text { 3.1.3 Two popular reports on most important } \\
\text { external underlying threats to dry forests } \\
\text { and possible responses - input to } 4.2,4.3 \text {, } \\
4.4 \text { and } 4.5 \text {. }\end{array}$ & $x$ & & $x$ \\
\hline & $\begin{array}{l}\text { 3.1.4 Press articles to appear in regional } \\
\text { economic magazines on role of and threats } \\
\text { to dry forests - input to } 4.3 \& 4.4\end{array}$ & $\mathrm{x}$ & $x$ & $\mathrm{x}$ \\
\hline \multirow{2}{*}{$\begin{array}{l}3.2 \text { Analyse policies } \\
\text { favouring } \\
\text { decentralisation and } \\
\text { devolution and their } \\
\text { efficacy in promoting } \\
\text { sustainable } \\
\text { management of dry } \\
\text { forests and improved } \\
\text { local livelihoods. }\end{array}$} & $\begin{array}{l}\text { 3.2.1 Paper on the role and impacts of } \\
\text { decentralisation }\end{array}$ & $\mathrm{x}$ & & \\
\hline & $\begin{array}{l}\text { 3.2.2 Policy document on decentralisation - } \\
\text { input to } 4.2-4.5\end{array}$ & & $x$ & \\
\hline \multicolumn{5}{|c|}{ 4. Activities cross-cutting all objectives } \\
\hline $\begin{array}{l}4.1 \text { Convene } \\
\text { discussions with } \\
\text { clients/stakeholders } \\
\text { to establish the } \\
\text { modus operandifor } \\
\text { policy dialogue } \\
\text { process }\end{array}$ & $\begin{array}{l}4.1 .1 \text { Annual plans in place for discussion } \\
\text { forums, workshops and attendence at policy- } \\
\text { related meetings }\end{array}$ & $X$ & $X$ & $x$ \\
\hline $\begin{array}{l}4.2 \text { Convene two } \\
\text { National forums and } \\
\text { one regional forum on } \\
\text { policy relevant to } \\
\text { forests to arrive at a } \\
\text { common } \\
\text { understanding of the } \\
\text { way forward in } \\
\text { managing dry forest. }\end{array}$ & $\begin{array}{l}\text { 4.3.1 Workshop reports - Items to be } \\
\text { covered will be (a) role of dry forests; (b) } \\
\text { main factors leading to successful forest } \\
\text { management; (c) constraints to implementing } \\
\text { sustainable forest management; regional in } \\
\text { year } 3\end{array}$ & $X$ & $X$ & $\mathrm{x}$ \\
\hline $\begin{array}{l}4.3 \text { Convene two } \\
\text { visioning and scenario- } \\
\text { building forums with } \\
\text { economic and natural } \\
\text { resource policy } \\
\text { makers to explore } \\
\text { alternative } \\
\text { development } \\
\text { trajectories }\end{array}$ & $\begin{array}{l}\text { 4.3.1 Workshop report: national levels (year } \\
1 \text { and 2); regional levels (year 3) }\end{array}$ & $x$ & $x$ & $\mathrm{x}$ \\
\hline
\end{tabular}




\begin{tabular}{|l|l|l|l|l|}
\hline $\begin{array}{l}4.4 \text { Make presentation } \\
\text { at two regional } \\
\text { economic forums on } \\
\text { role of dry forests } \\
\text { and extra-sectoral } \\
\text { influences }\end{array}$ & & $X$ & & $X$ \\
\hline $\begin{array}{l}4.5 \text { Stimulate debate } \\
\text { in donor and } \\
\text { development } \\
\text { organisations on the } \\
\text { role of dry forests } \\
\text { and forest products } \\
\text { in dryland Africa }\end{array}$ & 4.5 .1 Summary of discussions & & & \\
\hline
\end{tabular}

\subsection{Timelines}

The project will run from 2003 to 2005. Table 3.1 indicates the annual timing of the activities. Annual workplans will give more detailed timing of activities.

\subsection{Focus countries}

It is proposed that research effort will be concentrated in a few selected countries, although case studies on specific themes can cover other countries outside the focus list. Initially we will focus on Burkina Faso, Mozambique, Zambia and Tanzania.

\subsection{Institutional arrangements for project implementation}

\subsubsection{General}

CIFOR will serve as implementing agency and will manage the funds, including responsibility for reporting on technical and financial matters, though much of the work will be sub-contracted through national partners. CIFOR headquarters in Bogor, Indonesia will serve as formal focal point for the project but implementation will largely be delegated to its sub-regional Office located in Harare, Zimbabwe.

This proposal will set the broad set of activities to be tackled in the dry forest research programme. In addition an annual workplan shall be submitted by CIFOR each year. Small departures from the proposal and plans will require recording; major departures will require written concurrence with the donors.

CIFOR will also identify an external advisory team of individuals (members working in a personal capacity) in the partner Africa region and the donor countries/agencies. 


\subsubsection{Review, Reporting and Dissemination}

\section{Reports}

Progress reports will be submitted to donors and African partner institutions at least once a year. Following independent review missions jointly commissioned by the donors and CIFOR at the end of implementation year 2, a report, with recommendations on orientation of the project and need for continuation into a further phase will be prepared.

Not later than 2 months from approval of the first funding, a detailed workplan for implementation shall be submitted by CIFOR to the donor. Departures from that plan will require recording; major departures will require written concurrence with the donors for the specific activity.

As a distinct part of its implementation workplan, CIFOR will include a proposal for policy briefs and for popular information products to be derived from its research, its intentions for their dissemination in various fora and media, and steps intended to assess use made of the information or to apply research findings.

CIFOR will make all technical reports (paper and electronic) systematically available to all recognised Africa-based university faculties teaching forestry or environment in countries with significant dry forest areas. It will also target sub-regional organisations of member states or of conservation interest that deal with dry forests, especially CILSS, CILSS, IGAD; and research networks (AFORNET, IUFRO/SPDC, FORNESSA, CORAF, and the African Academy of Sciences).

\section{Reviews, Monitoring \& Evaluation}

There will be an independent review mission jointly commissioned by the donor(s) and CIFOR at the end of implementation year 2. This evaluation will make recommendations about duration and orientation of project extension beyond the 3 years.

A technical audit will be included in the joint mid-term review at year 2 and a budgetary provision made for it; this will focus on the significance of the work, potential for important breakthroughs, and efforts to draw the attention of practitioners and policy makers. 


\subsection{Budget}

Table 3.2: Budget breakdown

\begin{tabular}{|c|c|c|c|c|}
\hline \multirow[t]{2}{*}{ Cost item } & \multicolumn{4}{|c|}{ Cost, by year (SEK '000) } \\
\hline & 2003 & 2004 & 2005 & TOTAL \\
\hline Seconded Swedish expert & 850 & 850 & 850 & 2550 \\
\hline Internships (2No) & 300 & 300 & 300 & 900 \\
\hline $\begin{array}{l}\text { Research implementation costs } \\
\text { (see breakdown below) }\end{array}$ & 1800 & 1600 & 1800 & 5200 \\
\hline TOTAL & 2950 & 2750 & 2950 & 8650 \\
\hline \multicolumn{5}{|c|}{ Breakdown of "research implementation costs" } \\
\hline $\begin{array}{l}\text { CIFOR staff time, total } 18 \\
\text { months }\end{array}$ & 750 & 800 & 850 & 2400 \\
\hline Capital equipment (vehicle) & 300 & - & - & 300 \\
\hline Travel - research & 200 & 200 & 200 & 600 \\
\hline $\begin{array}{l}\text { Operating materials field \& } \\
\text { office supplies }\end{array}$ & 100 & 100 & 50 & 250 \\
\hline $\begin{array}{l}\text { Bursaries to part-support } \\
\text { selected dry-forest research }\end{array}$ & 100 & 100 & 100 & 300 \\
\hline $\begin{array}{l}\text { Sub-contracts to collaborative } \\
\text { partners }\end{array}$ & 200 & 200 & 200 & 600 \\
\hline $\begin{array}{l}\text { Workshops, meetings and } \\
\text { networking }\end{array}$ & 100 & 100 & 250 & 450 \\
\hline $\begin{array}{l}\text { Publications - } \\
\text { scientific/technical, popular }\end{array}$ & 50 & 100 & 150 & 300 \\
\hline Sub-total & 1800 & 1600 & 1800 & 5200 \\
\hline
\end{tabular}

\subsection{Main references}

Bullock, S.H., Mooney, H.A., Medina, E. (eds). 1955. Seasonally dry tropical forests. Cambridge University press, U.K.

Shepherd, G. 2002. Sustainable management of Africa's dry forests: a time to reengage. A Framework for a Dry Forests' Programme. Overseas Development Institute, London. 


\section{ANNEXES}

Annex 1.1: Key African countries containing tropical dry forests : basic data and some project examples

\section{THE FRANCOPHONE SAHEL}

\section{BURKINA FASO}

Burkina Faso - Physical

The vegetation is found in the three following zones:

The Sahel zone, with Acacia the dominant species;

The Sudan zone, characterised by the formation of tree and bush savannas, and shrub savannas, where the dominant species are the Combretaceae, with Cassia sieberiana, Pterocarpus erinaceus, Vitellaria paradoxa:

The Sudan-Guinea zone, with woodlands with Daniellia oliveriand Anogeissus leiocarpus, and riparian forests with Berlinia grandiflora.

The Ouagadougou fuelwood project designed a management model for natural forests characterised by the participation of rural populations, the protection of the forest's potential, and the establishment of a stable socio-economic system. The project has evolved management plans which ensure sustained forest production, tailoring them to socio-economic realities, in order to involve the rural population in the valorisation of the forest. The model is being applied to 24,000 ha of classified forest in Nazinon, and to the 40,000 ha of Kassou protected forest, and fallows in Bougnounou department. The model has made it possible to organise village forest management groups, to contribute to Ouagadougou's supply of firewood, and to create an additional source of rural employment and income. 


\section{CAMEROON (NORTH)}

Cameroon ( North) - Physical

Extreme North Province, where the village lands are heavily populated, with the almost complete disappearance of natural fallow:

The transition zone, where the marginal lands formerly set aside for pasture and the forest are now being cultivated;

The southern zone, where the land is less over-populated, and natural fallows are still possible. This Sudan-Sahel zone is characterised by Faidherbia albida and Prosopis africanabased woodlots.

The forest formations can be distinguished as follows:

Acacia-based thorny Sahel-Sudan shrub savannas :

Thorny Sudan-Sahel shrub savannas, characterised by Combretaceae :

Anogeissus leiocarpus and Vitellaria paradoxa-based tree and bush Sudan-Sahel savannas:

Middle Sudan forest savannas with Terminalia sp.; Grass prairies often associated with major riverbed riparian forests and a mosaic of terraced tree and bush savanna, and shrub savannas.

The most important results have been achieved in the Sudan-Sahel zone, where three research results have been of especial importance. Firstly, the discovery that protection from fire greatly regenerates pasture, and increases wood production. Secondly the realisation that it is not necessary to provide protection for timber regeneration, provided grazing capacity is not exceeded. Thirdly, the advantages of properly conducted cutting in order to limit invasive species and to maintain wood and grass productivity. 
CHAD

Chad - Physical

The Chadian Sahel is characterised by a thorny shrub steppe, dominated by the Acacia genus (nilotica, raddiana, seyal) and Balanites aegyptiaca:

To the north of the Sudan zone, a Sudan tree and bush savanna with Combretaceae and Faidherbia albida form the transition to the Sahel zone:

The vegetation in the Sudan zone is a >forest tree and bush savanna= with Isoberlinia doka, Prosopis africana. In some degraded savannas, Vitellaria paradoxa, and Khaya senegalensis can still be found. There are also dry forests with Anogeissus leiocarpus. There is Syzygium guineense-based woody vegetation along watercourses.

The most notable feature has been attempts at exploitation and regeneration conducted in conjunction with local populations, and aimed at specific species such as borassus palm, doum palm and gum arabic.

In all these cases, further modifications still need to be made, to streamline management and make it simpler and more efficient. But there is now considerable experience on which to build next steps.

\section{CÔTE D'IVOIRE ( NORTH)}

Côte d'Ivoire ( North) - Physical

The zone is characterised by the main savanna-type formations, such as woodland, grassy shrub savannas and riparian forests.

The woodlands, which begin at the northern limit of the Guinea savanna, generally consist of two strata: A tree and bush stratum, consisting of Isoberlinia doka, Vitellaria paradoxaand islets of Cola cordifolia and Antiaris africana; a grassy stratum composed of a carpet of graminaceous species, such as Andropogon hordeloïdes, and non-graminaceous species.

The riparian forests, lying along the banks of permanent waterways, consist of dense wood, making a continuous cover of vegetation.

The tree and bush savanna, and the dense shrub savanna, generally consist of medium- and small sized shrubs, and stunted trees, such as Detarium microcarpum, and there are shrub savannas typical of areas of cultivation after a few years of fallow. Bush fires are a very common anthropic phenomenon in the plant ecosystems of the north. 
Badenou classified forest was managed for timber production; firewood production through the use of logging by-products, through vegetative reproduction and through harvesting of shrubs in shrub savanna; and for forest protection and restoration. The innovative feature here was the place given to pastoralists in forest management, through the creation of livestock corridors, and the management of pasture (though no mechanism has as yet been set in place for conflict management between farmers and pastoralists).

\section{THE GAMBIA}

\section{The Gambia - Physical}

The vegetation is Sudan-Guinean, with some strips of climactic forest which still contain species with Guinea affinities. The natural populations are divided between different types of formation, with 2/3 tree and bush savanna, including mainly Combretum sp., Pterocarpus erinaceus, Elaeis guineensis, Cordyla pinnata, Terminalia macroptera.

Forest development (in Bijolo, etc.) focussed on protecting and improving forest reserves, and on organising the collection of dead wood for newly established sawmill units. The successful creation of both direct and indirect employment encouraged the authorities to attempt the same thing in forest areas outside reserves, on a community co-management basis.

\section{CAPE VERDE}

\section{Cape Verde - Physical}

The low regions are more or less arid, particularly in the south-south-west. The vegetation includes steppe formations with Acacia nilotica, Acacia farnesiana, Parkinsonia aculeata :

There are also savannas with Faidherbia albida and sometimes Ziziphus mauritiana. Calotropis procera is also found in these low regions, and Tamarix senegalensis on the coast, though this can be eliminated by the dunes covering it.

On the north-north-east slopes, there are some Lantana camara thickets.

Between 400 and $1000 \mathrm{~m}$, the vegetation has been destroyed and replaced by sugar cane and banana plantations.

On the highlands, there are dry herbaceous formations, and, on rocky soils, the vegetation is steppe, with Sonchrus daltonii. 


\section{GUINEA BISSAU}

\section{Guinea Bissau - Physical}

The densely leafed forest formations, including sub-humid forests with Afzelia africana, semi-dry forests with Erythrophlaeum guineense, mangroves with Rhizophora sp. and Avicennia sp., and ronier and palm trees, and riparian forests :

The open leafed forest formations made up of dry woodlands, degraded forest, and tree and bush savanna, with Pterocarpus erinaceus, Oxythenanthera abyssinica,... ;

The natural shrub formations which form the Parinari macrophylla-based littoral populations.

An experiment was conducted with IUCN in Dungal forest reserve. A land-use plan was established with a central reserve area, a controlled logging zone and a buffer zone.

\section{MALI}

Mali - Physical

The vegetation in the Sudan-Sahel zone is tree and bush savanna, with an upper stratum of Khaya senegalensis, a middle stratum of shrubs (Combretaceae and legumes), and a lower stratum of grasses. The Sudan-Guinea zone contains tree and bush savanna, in which can be found Vitellaria paradoxa and species such as Terminalia macroptera, Pterocarpus erinaceus, and gregarious species like Isoberlinia doka, and species from the savannas and forests of the Guinea zone, like Erythrophleum guineense.

In classified forest in Segou, participatory management was based on setting up associations with a monopoly on tree-felling, on the basis of a schedule of conditions. A plan for the division of income was devised between tax for the State, the forest investment fund, the village fund and the fellers. In Koutiala region, given the greater scarcity of the resource, the inter-village committee proposed that the administration sign a written agreement for green felling for local consumption, the sale of deadwood, and the exploitation of the resource for fodder and NTFPs. 


\section{NIGER}

Niger - Physical

A discontinuous steppe characterises the arid (Agadez) and "hyper-arid" (Bilara) zones;

The Sahel zone is characterised by open shrub and tree formations - a steppe with several species of Acacia distributed accorded to soil characteristics. The stiger bush= can be found there, dominated by Combretaceae, Tiliaceae and Mimosaceae. The vegetation of the Sudan zone is savanna with a herbaceous stratum, with mainly long perennial grasses (Andropogon gayanus). Woodlands with Anogeissus leiocarpus can be found, as well as various Combretaceae.

The experience in Niger in the management of classified forests (Guesselbodi) or protected forests (Buyanga), is very interesting. Several constraints - technical, organisational, tenurial B were encountered in these activities, but the Domestic Energy Strategy implemented under the Energy II project, achieved several development objectives. The local populations, encouraged by incentives, also began to manage in non-classified forests, initially by quota, and then by management plans and coupes. The village groups, known as "rural markets", were able to obtain rural concessions for management of the resource for livestock, fuelwood cutting, and NTFP gathering). Trees began, as a result, to acquire monetary value in the eyes of the local populations.

\section{SENEGAL}

Senegal - Physical

The forest resources, which cover approximately $25 \%$ of the land area, are made up primarily of tree and bush savanna and shrub savanna. Hence we find:

A Sahel zone, characterised by Acacia and Balanites aegyptiaca, with a tree and bush savanna transition zone, with Faidherbia albida and Combretum spp.

A Sudan zone, which is particularly that of the wooded savanna with Khaya senegalensis and Adansonia digitata:

A sub-Guinea zone, with deciduous populations, dominated by Parinari excelsa, Bombax Costatum,etc.

Specific plant formations, such as Elaeis guineensis, Casuarina equisetifolia, etc., along the coast, and mangroves with Avicenia and Rhizophora. 
The sylvo-pastoral management project in the north can be quoted as an example of involving pastoralists in order to protect natural regeneration and control the process of degradation by transhuman livestock. The results achieved, in reconstituting potential through fencing, showed the possibilities of these techniques.

Further insights come from the management of Koumpentoum classified forest, which introduced a ban on felling by non-locals. The sharing of income between local councils and the State, the system of paid guards, the differentiated taxation which works in favour of managed zones, and the allocation of land for felling according to its wealth, all proved determining factors in its success.

\section{THE ANGLOPHONE SAHEL}

\section{KENYA}

KENYA - Physical

According to the Forest Resource Assessment (FAO, 2000) 'Tropical Dry Forest' covers a very small area of the country, 'Tropical Shrubland' being the dominant vegetation type.

Key species: These include Acacia spp (in the highlands) and Acacia wooded grasslands in a broad belt around the highlands between 1,200 and 1,500m. Shrubland species include Commiphora with emergent Adansonia digitata.

Changes in forest cover:

Between 1990-2000 it has been calculated by the FAO as occurring at a rate of $0.5 \%$ per annum ${ }^{22}$. Most of the deforestation is reported to be occurring in woodlands (the indigenous high forests are protected and change is estimated to be around $0 \%$ for these forests).

\section{Relevant Government Initiatives/Decentralisation}

The Kenya Forestry Master Plan was a planning document for the forest sector in Kenya. It was initiated in 1991 and completed in 1994 ${ }^{23}$. Key emphasis was given to a number of issues including promoting the principle of multipurpose management, especially in indigenous forests; enhancing social forestry and farm forestry, and reducing pressures on indigenous forests; building capacity through education, training and research and giving due recognition to the importance of wood as the predominant rural and urban energy source

\footnotetext{
${ }^{22}$ based on countries in the region as no figures were available to the FAO for Kenya itself

${ }^{23}$ Ministry of Environment, www.mec.go.ke/biodiveristy.html
} 
The Ministry of Environment has highlighted the need to focus more on dry forests and cites the example of the dry mountain forests on the Kenya-Uganda border. Plant germplasm here has been conserved through the strong traditional conservation mechanisms of pastoral communities, and changes in the lifestyles of pastoralists may lead to a breakdown of traditional systems. 


\section{Some examples of projects in Kenya}

Management methods and the species selection for irrigated fuelwood plantations (University of Helsinki - Tropical Silviculture Unit. Project - 1984 -1993)

Research was carried out in the semi-arid Tana River basin in eastern Kenya and in cooperation with researchers from the Kenya Forestry Research Institute (KEFRI). Other research topics included rehabilitation of the degraded savanna vegetation using rainwater harvesting, and eco-physiological and genetic studies on the water utilisation and adaptation of an introduced eucalypt species both in the irrigated plantations in Kenya and over its natural range of distribution in Australia. The traditional use trees at the Tana River was an additional topic jointly studied by Finnish and Kenyan researchers and the local communities.

Techniques used included microcatchment water harvesting to improve the establishment and early growth of planted seedlings, a method which can be used for small-scale tree planting in dryland rehabilitation, but which is not applicable in supplying fuelwood for concentrated populations.

\section{Potential of Indigenous fruit trees in arid areas ${ }^{24}$}

Recent work in Kenya has been looking at the potential of indigenous fruit trees in arid areas to supplement local diets. The research has suggested that there is little information on the identification, use and management of such trees by the communities. Fruit trees are being lost as a result of the exploitation of the land for charcoal to feed urban markets. The research indicated that little planting is carried out of the fruit trees and that where planting has occurred, the seedlings have been planted based on what were available in local government or project tree nurseries. There is a need for more indigenous fruit tree research.

Kenya ${ }^{25}$ is a country which has not as yet seen fit to legalise any kind of co-management of forests with local people. The only approaches so far agreed are revenue-sharing approaches (like Zimbabwe's CAMPFIRE) or economic activities in buffer zones to increase local cooperation. Research into CFM projects in Eastern Africa highlighted a number of issues relevant to Kenya. For instance, participation is encouraged and sustained through the receipt of agreed benefits, and should these cease or decline, local support tends also to decline. Additional problems in this form of project relate to the cost of supervising the distribution of benefits which may be substantial, and cause forest management costs overall to rise. Also, management roles given to local people are often limited.

\section{Donor Funded Projects}

The main focus of donor funded NR projects in Kenya is on rangeland and arid and semi-arid land issues, with a number of projects funded through GTZ, and CIDA, (research by IDRC).

\footnotetext{
${ }^{24}$ Muok, B. O, Owuor, B, Dawson, I and Were, J. The Potential of Indigenous Fruit Trees: Results of a survey in Kitui District, Kenya. Agroforestry Today 12 (1)

${ }^{25}$ From Alden Wily, op cit
} 


\section{Forest laws etc in Kenya relating to devolution/decentralisation ${ }^{26}$}

The new National Forest Policy was launched in 1999, and the Forests Bill in 2000. The Bill provides for Forest Associations to be established by person/s living within $5 \mathrm{~km}$ of a state or local forest - amounts to approximately $1.6 \mathrm{~m} \mathrm{ha}$. The Kenya Forest Services are promoted as the owner of State Forests and local authorities as the owner of local forests. No opportunity for communities to create their own forest out of commons or re-secure ownership of adjacent reserves is offered, however Forest Associations may apply to manage a state or local forest through Joint Management agreement.

\section{SUDAN}

A comprehensive overview of the decentralisation and resource management issues in the Sudan and the overall Sahel region is given the book 'Local Forest Management in the Sahe ${ }^{27}$. This report draws on the experience from a number of dry forest management projects in the region, including the SOS Sahel project in Sudan.

Forest Use: most woodlands are traditionally used by pastoralist groups for some weeks or months during the year. Forest management projects and policies tend to ignore traditional pastoralist usufruct rights.

Local Management: in areas where local management is allowed, the woodland is usually well protected. For example, guards may be employed by the local community and paid through fines or revenues from sale of forest products; community forest committees may be established.

Outside of reserved forests: Though there may be little formal forest planning, informal management does exist, and most woodland areas are under some form of local management.

The Forest Service and Forest Law/Codes: Many forest codes have been inherited from colonial times and many have been retained as frameworks with rules and regulations developed by the Forest services.

\footnotetext{
26 From Alden Wily, L (2000) The democratisation of forest management in eastern and southern Africa. International Forestry Journal Review 2(4) 2000 pp 287 - 294

${ }^{27}$ Kerkof, P (2000), SOS Sahel, London. (This book presents the results of research commissioned and funded by SOS Sahel and supervised for them by Gill Shepherd and Duncan Fulton.)
} 


\section{SUDAN - Physical}

According to the White classification, the dominant 'dry forest/woodland' types in the Sudan fall into the following categories:

In the North - Sudanian Woodland, Sahel acacia woodland, semi desert grassland and shrubland.

In the mid-country - Acacia wooded grassland and undifferentiated Sudanian woodland

In the south - Sudanian woodland with abundant Isoberlinia.

Rainfall Rainfall in the savanna areas is confined to a few months followed by a long hot dry season. Areas which receive more than $300 \mathrm{~mm}$ rainfall per annum consist of shrub or tree vegetation dominated by Acacia spp.

The FAO assessment divides the woodland savanna into two types: high rainfall ( $>900 \mathrm{~mm}$ ) and low rainfall $(<900 \mathrm{~mm})$.

Anogeissus-Khaya-Isoberlinia- found on ironstone soils with rainfall of 900 to $1300 \mathrm{~mm}$. It varies in composition due to variations in climate, soil and the effect of different degrees of human disturbance.

Within the low rainfall savanna (covering most of central Sudan and east of the flood area), a number of sub-types have been identified. The drier areas are dominated by Acacia spp with broadleaved deciduous trees becoming predominant in the wetter areas.

Changes in Forest Cover: A recent report in the European Tropical Forestry Network (ETFRN) Newsletter suggests that this vegetation is being lost at a rate of 480,000 ha per annum (of which $10 \%$ is reforested) ${ }^{28}$. In 1993 a number of government decrees were passed which declared $7.6 \mathrm{~m}$ ha as forest reserves $-453,000 \mathrm{ha}$ of this are plantations established through reforestation, and 42,000 ha are community woodlots established through afforestation. The FAO estimates change in forest cover (1990-2000) to have occurred at a rate of $-1.4 \%$ per annum.

\footnotetext{
${ }^{28}$ Luukkanen, O; El Fadl, M A and Mohamed, A G (1999) Dryland Forestry and Agroforestry in the Sudan. ETFRN (28) June-August 1999
} 


\section{Some examples of project experience in the Sudan}

\section{The SOS Sahel Project in El Ain, Kordofan}

The area had a resident population of around 7,000, and was also used by nomadic pastoralists. Legislation permitting the legal appropriation of forest resources by local communities through gazettement was enacted in 1989and the project capitalised on this. Once underway, local communities took control and developed their own management systems. Village Management Plans were developed with the assistance of the project, which also assisted them in writing up the plans and in developing a forest inventory system based on local forest products rather than wood volume. Overall - people in the settled communities respect the management rules and most offences are settled by informal means.

There is now the threat of the expropriation of village lands by commercial interests. Large areas of state forest reserve, which includes village-registered woodlands, have been leased by the forest service to a commercial company. It is feared that, though these resources have so far been saved, they will be lost when the project is no longer there. Village forest registration is still centralised nationally, but decentralisation may transfer responsibilities for natural resources from the forest service to local government.

\section{Sudan-Finland Co-operation - Gum Arabic ${ }^{29}$}

Gum arabic is an important NTFP obtained from Acacia senegal. The traditional agroforestry system for managing and tapping $A$ senegal is reported as being one of the best examples of sustainable dryland agroforestry. The Finnish Co-operation project started in 1989 with Enso Forest Development Ltd looking at rehabilitation of the gum belt and introduction of Prosopis juliflora in forest plantations and agroforestry systems. Irrigated fuelwood plantations were also experimented with. From 1991 most of this programme was discontinued. In the wake of the Gulf War, (and the Sudan Government's decision to back Saddam Hussain) and similar situations occurred with almost all international development projects in the Sudan. However, key results at that point included the findings that natural Acacia seyal forests on clay soils can be sustainably managed with appropriate silvicultural interventions; in the sandy soil areas, Prosopis juliflorahas favourable effects on agricultural crops. From 2000 the Tropical Silviculture Unit at University of Helsinki has been continuing research in Sudan, focussing on the development of traditional $A$ senegalagroforestry. Key aims of the project include finding new artificial and natural regeneration techniques; optimising tree-crop interactions; identifying ecophysiological characteristics in A senegal and agricultural crops which can be used to predict agroforestry system performance.

\footnotetext{
${ }^{29}$ Luukkanen et al, op cit
} 
UNEP success story - SOS Sahel Community Forestry Project in Ed Debba, N. Sudan

The main achievements of this project have been to define an efficient, cost-effective, community-based system of encroachment control in a very difficult environment; to demonstrate to some 52,000 people that they can control and manage this environment; and to alleviate the fear of having to abandon homes and relocate elsewhere. The key achievements include:

- comprehensive protection measures to limit wind velocity - comprising the planting of Prosopis juliflora outer shelterbelts and Eucalyptus windbreaks around crop areas and settlements; dune fixation and land rehabilitation; soil and water conservation; building on indigenous knowledge and experience to introduce more sustainable, cost-effective protection measures.

- Continuing rehabilitation and protection of agricultural land-25 per cent increases each year.

- Increased fodder and fuelwood through coppicing Prosopis juliflora and harvesting the pods;

- A high degree of community involvement and empowerment in activities, through farmers' and women's committees

- Increased incomes for women from activities such as tree nurseries, home gardens;

- Protection of housing, water points and infrastructure.

NORTHERN NIGERIA

NORTHERN NIGERIA - Physical

Vegetation Patterns Tree vegetation is rare in the northern Sudan and Sahel zones. In the Guinea zone, acacias are relatively rare. Northern Nigeria is dominated by Sudanian woodland with Sahel acacia woodland in the northeastern tip. In the Sudan zone, acacias also occur but are not as dominant (except on special soil types). Many of the tree species found here are deciduous in the dry season.

Rainfall The seasonal movement of the Inter-Tropical Convergence Zone leads to contrasting wet and dry seasons and a prominent north-south rainfall pattern. The northern areas receive much less rainfall and have a shorter wet season. For example in N Eastern Nigeria, the mean annual rainfall is less than $500 \mathrm{~mm}$ receiving more than $100 \mathrm{~mm}$ in only two months a year ${ }^{30}$.

Forest Cover Change The FAO assessment cites deforestation as one of the most important environmental issues in Nigeria. Forest cover change between 1990 and 2000 is estimated at a rate of $-2.6 \%$ per annum.

\footnotetext{
${ }^{30}$ Blench, R (1999) Traditional Livestock Breeds: Geographical Distribution and Dynamics in relation to the Ecology of West Africa. ODI Working Paper No. 122. Overseas Development Institute, London.
} 
According to Blench (2001) ${ }^{31}$ internal capacity in policy making within Nigeria is good but implementation and compliance are bad - the federal system makes it possible for states to exercise autonomy in this area. 'Green' issues were previously the responsibility of different ministries - for example, deforestation was the responsibility of the FD. However, a new ministry of the Environment has been created with potential responsibility for Forestry and Land Resources amongst other things. The reports highlights a need for external agencies to look at strengthening regulatory frameworks.

\section{Projects in Northern Nigeria}

Some donors have hesitated to commit funds to Nigeria in recent years, and those that have, have mainly concentrated on the rainforests of the south, such as those in the Cross River area.

Similarly the Forestry Research Institute of Nigeria, based in the south in Ibadan, would seem to have conducted little research in the north. The University of Kano has continued with modest agroforestry trials, and with seed collection.

\section{UNEP Technical Co-operation 1998 - 'Afforestation in Kano and Jigawa States' Sudan savanna zone $e^{32}$}

The project identified the following problems: increasing areas under intensive agriculture with decreasing areas of extensive grazing land and a lack of fodder; high rates of population growth; increasing demand for fuelwood; inadequate forest management polices; severe wind and water erosion; and prolonged moisture deficiency causing stress on crops. The project improved effective soil conservation and increased vegetative cover both in well- maintained shelterbelts and woodlots, and through the regeneration of indigenous vegetation and farm based activities. It improved soil fertility and crop productivity through improved micro-climate, and through using manure, which was previously used as fuel. It also strengthened community organisations.

\footnotetext{
${ }^{31}$ Blench, R (2001) Briefing Paper: Desertification and Land Degradation Nigeria- Existing situation and future options. Prepared for FCO.

32 From - UNEP 'Success Stories'. www.unep.org/unep/envpolimp/techcoop/8.htm
} 
GHANA

\section{Relevant Government Initiatives/Decentralisation}

According to Kotey et al $(1998)^{33}$, a plan for savanna forest and woodland management was in the process of being developed in 1998. The report documents some of the Government initiatives in decentralisation in the country and outlines what has worked/not worked. Forest reserves are owned by the landholding communities and managed by the Forest Department. The 1994 Forest Policy and Action Plan recognises the importance of 'community rights' and various initiatives are underway to explore and implement strategies for increasing the benefits local people obtain from forest reserves. Different stakeholders active in Ghana's forests include- Ministry of Lands and Forestry (formulation and coordination of forestry and land policy), Forestry Department (executing and operational agency responsible for forest management, protection and development). Since 1998, district assemblies have been the main decision making body of local government - elected representatives and some nominated members from all the towns and villages in each of the 110 districts in Ghana. Some have been active in environment and forestry matters whilst others have simply seen it as a source of revenue.

In 1980s, failings of the policy and legislation system were identified to include excessive centralisation of forest management; the non-integration of rural production systems into forest management; the absence of a role for communities and industry in forest management. In the 1980s and the early 1990s - under social forestry - the Forest Department encouraged communities to establish village, communal, individual or family woodlots. There was support in the north of the country from ODA (DFID), the World Bank and FAO. Collaborative management approaches were initiated in 1992/3.

\footnotetext{
${ }^{33}$ From Kotey, $\mathrm{N}$ et al (1998) Falling into place. Policy that works for forests and people series No.4, Ghana Country Study
} 
GHANA - Physical

Vegetation Types The two dominant ecological zones within Ghana are closed forest (covering about $34 \%$ of the country or $8.22 \mathrm{~m} \mathrm{ha}$ ) and savanna (covering about $66 \%$ of the country or $15.62 \mathrm{~m} \mathrm{ha})^{34}$. According to the classification of vegetation types developed by White (1983), northern Ghana comprises vegetation of the Sudanian Woodland type ranging from that dominated by Isoberilina to undifferentiated woodlands. The very northern tip is dominated by Sahelian woodland.

The FAO assessment notes that savannas cover the northern $2 / 3$ of the country and that the population increases towards the north where the land is exploited for agriculture. However, differences appear to arise between the two classification systems and the FAO assessment names Guinea savanna woodland as the dominant savanna in the north with a small area of Sudan savanna in the North East of the Country. This area has the highest density of rural population, very sparse tree cover including various species which provide additional food for the local population.

Rainfall/climate $\mathrm{N}$ Ghana lies between $8^{\circ}$ and $11^{\circ} \mathrm{N}$ latitude at an altitude of $200-300 \mathrm{~m}$. The mean annual temperatures are between 25 and 30 degrees centigrade and the wet season falls from May to September ${ }^{35}$.

Forest Cover Change Rates of change in forest cover have been estimated by the FAO as $1.7 \%$ per annum (1990-2000). According to the National Report to the Second COP of the UNCCD (1999), the savanna zone covers approximately $15.6 \mathrm{~m}$ ha of the country. Of this, $14.7 \mathrm{~m}$ ha are unreserved and being destroyed at an estimated annual rate of $20,000 \mathrm{ha}$.

\section{The role of bushfires in shaping savanna vegetation in Ghana}

Savanna vegetation has evolved under conditions of annual bushfires, which have increased through human activities. In the last 20 years, bushfire has become one of the most dramatic forces which have shaped the biotic community. The practice of bush burning is so deeply engrained in the traditional farming systems that trying to suppress it would mean cutting off the means of subsistence of small scale farmers who do not have adequate funds to employ labour for land clearing.

More than $75 \%$ all energy requirements in Ghana are met from fuelwood and charcoal. Estimates for annual fuelwood consumption for the whole country are around $16 \mathrm{~m}$ cubic metres. Much of the urban fuelwood comes from the savanna and transitional zones where there is now increasing local scarcity.

The National Environment Action Plan was initiated in 1988 and as of 1999 was at the implementation stage ${ }^{36}$. Additional programmes exist which also form part of the

\footnotetext{
${ }^{34}$ Bushfires in Ghana- IFFN No. 15, September 1996. www.uni freiburg.de/ fireglobe/ iffn/ country/gh/.htm

${ }^{35}$ ILEIA Newsletter, September 1999 Northern Ghana Programme. Pp $36-37$

${ }^{36}$ Republic of Ghana (1999) National Report to the Third Session of the Conference of the Parties to the United Nations Convention to Combat Desertification
} 
national sustainable development agenda. Of direct relevance to forest management are the Natural Resources Management Programme (savanna resource management is one component which involved forestry, agriculture, land management and conservation); the Decentralisation Programme (commitments to transferring major developing planning to district assemblies). District and Community Management Committees have been established within the District Assemblies to advise on local environmental issues and assist in the formulation of polices and programmes. The Government also encourages the development of Community Forestry Management Committees.

In the Ghanian Constitution (1992), there are statements stating that responsibility for the conservation and sustenance of the environment extends to all citizens. In 1994 the Government introduced the Forest and Wildlife Policy which outlined the Governments overall objective for forestry: The forest and wildlife policy aims at the conservation and sustainable development of the nation's forest and wildlife resources for maintenance of environmental quality and perpetual flow of optimum benefits to all segments of society ${ }^{37}$. In 1998 the new Forestry Act was proposed, aimed at consolidation and replacement of all existing forestry legislation. It proposes clear identification of land-and forest-holding communities as the primary clients of a proposed Forest Service, which will pursue SFM.

Examples of Northern Ghana Projects

\section{(i) The Ghana Environmental Resource Management Project (GERMP)}

The project was launched in 1993. It springs from the fact that the environment is a cross-sectoral issue, and many Government departments are being decentralised to local levels. The project aims to put in place the institutional and technical capability required for effective environmental monitoring, policy formulation and coordination; to support a pilot programme to combat soil degradation and erosion and to help prevent further destruction of coastal zone resources.

(ii) The Cooperative Integrated Project on Savanna Ecosystems in Ghana (CIPSEG) (UNESCO)

This project recognised the role of religious beliefs and traditional values in preserving areas of the climax vegetation in the savanna. The project firstly carried out a number of studies to demonstrate that sacred groves had a higher biodiversity than the degraded areas and then to propagate seedlings from these groves to be used with other plants for enriching the buffer zones of the sacred areas/groves. The project has also looked at the containment of bushfires, and at restricted harvesting for fuelwood and poles in order to encourage the natural regeneration of

\footnotetext{
${ }^{37}$ Kotey, N A et al (1998)
} 
indigenous species. Micro-catchment techniques were used for planting in degraded areas and resulted in about $80 \%$ survival of the seedlings. The project found that land was always owned by someone, and that it was vital to identify resource owners and integrate them into the project. The traditional knowledge of the medicine men, often seen as the traditional custodians of the flora, was also necessary. Considerable effort was put into awareness raising of the problems of land degradation, education to help people acquire the knowledge to management the degraded areas etc.

\section{(iii) Community Savanna Rehabilitation Project (CSRP)}

This project is being implemented by the Environmental Protection Agency with Local Chiefs and community based associations in the Jirapa Traditional Area of the Jirapa/Lambusie District (Upper West Region). Its goal is to promote a sustained improvement in the well-being of savanna communities.

\section{(iv) Research on the role of trees in the livelihood system}

Research in NE Ghana on the role of trees in the livelihood system ${ }^{38}$ highlights the role of 'sacred groves' located throughout the area. Usually quite small with dense vegetation, there are strict rules governing entry to the area, cutting of fuelwood and collection of medicinal plants. Key issues from the research include the following:

- The vast expanses of bush are owned in a general sense by lineages but lack of control is beginning to become problematic as charcoal production is increasing in economic importance and charcoal burners are able to exploit loopholes in the system.

- The charcoal and fuelwood trade is seen to be increasing, due to the growth of urban centres and the spread of small scale beer brewing.

- Mobile pastoralist groups claim the bush as a free resource whilst the indigenous people claim that they own it.

- Regional Governments have introduced taxes on loads of fuel and charcoal entering major settlements. They do nothing to discourage the trade as it is a useful source of income. The IBRD-funded Forestry and Wildlife Resource Management Project envisages a major expansion of the charcoal trade.

\footnotetext{
38 Blench, R (2001) Human Culture and Savanna Landscapes of Northern Ghana (draft). Overseas Development Institute, London
} 


\section{SOUTHERN AFRICA}

\section{ANGOLA}

Angola - Physical

Types of vegetation According to the vegetation classification system developed by White, the dominant vegetation types in Angola are:

- Wetter Zambezian Miombo Woodland

- Zambezian dry deciduous forest and secondary grassland

- Mosaic of Brachystegia bakerana thicket and edaphic grassland

The FAO assessment (FRA 2000) notes that evergreen dry forests have been distinguished in the Upper Zambezi region (rainfall 1,100 - 1,200mm), dominated by Cryptosepalum exfoliatum. This forest type is classified as closed forest as there is an almost total absence of a grassy layer. Coast forest is reported as being very degraded - mainly as a result of cutting for firewood and charcoal. The miombo woodland stretches over almost all the inland highlands of Malanje, Benguela and Huila. Two species (Baikiea plurijuga and Ricinodendron rautanenii) form varying closed and pure stands of commercial value respectively for industrial wood and oil products.

The coastal area is characterised by a scarcity of vegetation despite scattered species including Brachystegia, Julbernardia and Isoberlinia. The civil war in the country means that these reserves are coming under even greater pressure as this coastal area is home to a large proportion of the Angolan population as well as those displaced as a result of war $^{39}$.

Forest Cover Change Data relating to changes in forest cover have been estimated by FAO based on historical data and remote sensing results. The estimated rate of forest cover change between 1990 and 2000 was $-0.2 \%$ per annum.

A Forestry Outlook Study for Angola has been published by the FAO ${ }^{40}$. The study outlines the key institutional arrangements in place in Angola as well as socioeconomic and other issues which impact on the forest sector. The key points include:

\section{Institutional/Legislative Background}

The forest sector is within the Ministry of Agriculture and Rural Development, especially under the Institute for Forestry Development (IDF)-represented in all 18 provinces. Angola has no Forest Law - the sector still uses the Forest Ordinance established during colonial times. The Directorate of Agriculture and Forests was established in the early 1990's, to work in parallel with the IDF. However, it is poorly represented at local levels and it only operating out of headquarters in Luanda.. Private sector participation in forestry has been affected by a number of issues, including civil unrest. In 1992 the Land Law was approved which included principles

\footnotetext{
${ }^{39}$ From - FOSA Country Report - Angola. www.fao.org/DOCREP/003/X6772E/X6772E03.htm

${ }^{40}$ FOSA Country Report - Angola (op cit)
} 
stating that local community land rights will be protecting. However, it does not cover all national territory and it fails to cover in any but the most intangible way, systems which govern access and rights for at least $95 \%$ of the country.

\section{Socio Economic Issues/Other}

Civil war and displacement have impacted on forest resources around cities/urban areas and on economic growth overall. One key gap identified related to gathering of information (even at basic level) - without which is difficult to persuade decisionmakers to pay attention. This lack of basic forestry information has been raised by several authors.

\section{BOTSWANA}

Botswana - Physical

Vegetation types: According to the FAO assessment, the vegetation types in Botswana consist almost entirely of tropical dry forest (approx. 40\%) and Tropical Shrubland (approx. $60 \%$ ). The vegetation analysis carried out by White (1983) identifies the predominant vegetation types as 'Kalahari Acacia wooded grassland' and 'transition from undifferentiated woodland to Acacia deciduous woodland and wooded grassland'. The vegetation of extreme south-west Botswana is sparse, a result of low and erratic rainfall.

Climate and Soils: Annual rainfall varies from $650 \mathrm{~mm}$ in the north to $255 \mathrm{~mm}$ in the southwest. Open woodlands and dry deciduous forests cover $60 \%$ of the country with the main forested areas being the north and northeastern parts.

Forest Cover Change: The FAO estimate for the change in forest cover between 1990 and 2000 is $-0.9 \%$ per annum.

A Forestry Outlook Study has been prepared for Botswana. Key points from this study include:

- Forestry is a sub-sector of the Ministry of Agriculture.

- The Forest Act (1968) - effectiveness is limited by traditional nature of land tenure system. The act itself is mainly concerned with Forest Reserves, which cover approximately only $0.8 \%$ of the country.

- A countrywide review of the National Forest Policy and Forest Act was undertaken between 1995 - 1997. A draft has now been produced which builds on the existing goals and includes:

- Encourage, involve and assist local communities in the conservation, management and sustainable utilisation of forest resources

- Create an enabling legal and institutional environment so as to effectively implement the policy

- Success rate of plantations and woodlots in Botswana has been modest - often 
attributed to lack of site management or water but other issues include planting on unsuitable sites (outside natural range etc). Research and a re-evaluation of plantations and woodlots are underway ${ }^{41}$.

\section{MALAWI}

Malawi - Physical

Vegetation types

Under the classification system developed by White, the dominant vegetation types are:

- Wetter Zambezian Miombo woodland

- North Zambezian Woodland

The FRA assessment shows tropical dry forest being confined to the south of the country. Miombo woodland is present on the peneplains and mountain slopes of moderate altitude. Munga woodland (Piliostigma-Acacia-Combretum) is found at lower altitudes on more fertile soils. Vegetation of the lakeshore and poorer lowlands consists of mopane woodland (Colophospermum mopane). Whilst secondary wooded grassland is reportedly uncommon, wooded farmland with scattered trees is widespread (especially on more fertile soils).

Forest Cover Change: The FAO estimate for the change in forest cover between 1990 and 2000 is $-2.4 \%$ per annum ${ }^{42}$.

Key general NR legislation: 1996 - Environmental Management Act (framework for ongoing program of sectoral policy, institutional and legislative reform in favour of the environment ${ }^{43}$ Environmental Affairs Department initiates the National Environmental Action Plan.

Forest related Legislation/Institutional arrangements: National Forest Policy (1996); Forestry Act (1997)

Both these acts have helped remove restrictions to access and use of forests and have promoted the involvement of communities in management ${ }^{44}$. However, weaknesses still exist. Community management is still excluded in already-created Forest Reserves.

\footnotetext{
${ }^{41}$ FOSA Country Report - Botswana (op cit)

42 This figure is based on extrapolation of data obtained from 1973 and 1991 . No recent information is available to confirm this result.

${ }^{43}$ www.compass-malawi.com/vision.htm

${ }^{44}$ Alden Wily, L (2000) op cit
} 
There are also contradictions in terms of use and 'disposal' of forest products between the Forest laws and the draft national land policy. Generally, experience in local management to date suggests that local natural resource management committees are finding they do not have adequate powers to be effective or the 'socio-legal identity' to enforce their rules.

Malawi has just been through a very successful National Forest Programme process, under the aegis of PROFOR.

\section{MOZAMBIQUE}

Mozambique - Physical

Climate: There are two distinct seasons - winter and summer, with rainfall mainly restricted to the summer season which takes place between October and April. Rainfall decreases from North to South and from the coast to inland areas.

Vegetation types: According to White, the dominant vegetation types are:

- Drier Zambezian miombo

- North Zambezian woodland

Forest Cover Change: The FAO estimate for the change in forest cover between 1990 and 2000 is $-0.2 \%$ per annum.

Important Laws relating to forestry in Zambia include the National Forestry Policy (1998) and the Forests Act (1999). In these laws a clear distinction is made between local and national forests - community involvement is only allowed in local forests ${ }^{45}$. Whilst in theory local communities are 'owners' of local forests, it is complex to acquire the required tenurial status - which requires legal negotiation with local government - and this is likely to hamper activation of this theoretical ownership.

A research project for the FAO focusing on the production of NWFP raised a number of issues which echo the concerns of other authors in the region regarding the sustainable production and effective marketing of NWFP as a means of sustainable NRM ${ }^{46}$. Over $55 \%$ of Zambia's land area is covered by forest consisting of Brachystegia, Isoberlinia and Julbernardia.

There is no particular institution responsible for all non-wood forest products, but there are 4 government departments with overall responsibility for national forests and wildlife: The Forest Department, Natural Resources Department, Fisheries Department, and the Department of Wildlife. Constraints identified by the study in

\footnotetext{
45 Alden Wily (2000) op cit

${ }^{46}$ www.fao.org/docrep/X5325e/×5325eOa.htm
} 
terms of promoting and further developing NWFP included lack of information on NWFP in Zambia, manpower shortages, inadequate funding, and under-developed marketing structures.

NAMIBIA

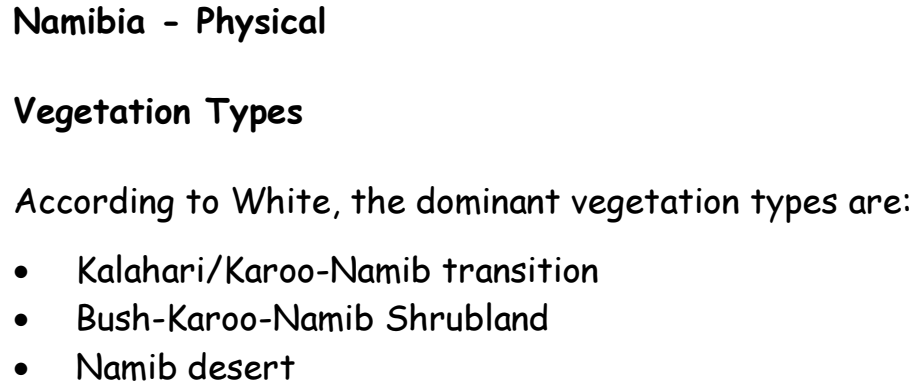

The FRA 2000 shows a mixture of tropical dry forest and tropical shrubland dominating the east of the country. In the north of the country there is a mosaic of steppes and savanna woodlands. North east of Oshand comprises semi-deciduous savanna woodlands.

Climate/Rainfall: The average rainfall ranges from $0-25 \mathrm{~mm}$ in the west to $500-600 \mathrm{~mm}$ in the north east ${ }^{47}$. Rainfall is highly erratic both temporally and spatially. Only $8 \%$ of the country receives more than $500 \mathrm{~mm}$ per annum.

Forest Cover Change: The FAO estimate for the change in forest cover between 1990 and 2000 is $-0.9 \%$ per annum. Reports published in 1992 cite fuelwood gathering and grazing as major causes of deforestation. Wild fires are also mentioned as a threat, especially in the Caprivi strip.

Namibia has been the focus of several papers reviewing the institutional changes which have taken place and their impacts on local management.

Changes in Government/Legislation affecting forest management:

When Namibia obtained independence in 1990, 40.8\% of the land was allocated to black homelands which supported a population of 1.2 million. These homelands are now recognised as communal lands to which local people have access to, although land ownership is vested in the $S t a t e^{48}$. State regulation of wildlife and forestry products is extremely difficult to enforce as a result of the great distances form administrative centres and the lack of government resources.

\footnotetext{
${ }^{47}$ From: Corbett, A and Jones, B T B (2000) The Legal Aspects of Governance in CBNRM in Namibia. Paper presented at the $2^{\text {nd }}$ CASS/PLAAS Regional Meeting, Cape Town, 16-17 October 2000. www.cbnrm.org/library/files/corbett_001.pdf

${ }^{48}$ From: Jones, B T B (2000) Community Management of Natural Resources In Namibia. IIED Drylands Issues Paper No. 90.
} 
In 1990, SWAPO came to power and has committed itself to decentralisation of decision making. A decentralisation policy outlines which government functions should be shifted to Regional Councils. However there is no administrative unit below the Regional Council (except for municipalities); the Rural Councils currently have little power, few officials and no authority to raise revenues for themselves ${ }^{49}$.

In 1997, the National Land policy was adopted. This recognises that steps need to be taken to clarify issues relating to legitimate access and rights to land. There is growing tension in several parts of the country, between those who fence off their land for private use and the majority who are then excluded from it. The Communal Land Reform Bill is currently in Parliament.

Research on the current legislative framework for CBNRM in Namibia highlights several gaps that still exist between policy intent and implementation. Communities face a number of problems in meeting the conditions set by the policy instruments for gaining rights over resources. Policy needs to provide mechanisms to reach a balance between community rights and individual rights.

There is also a National Programme to Combat desertification (NAPCOD) which was established in 1994. Its objective is to combat the process of desertification through the promotion of sustainable and equitable development of natural resources. A suite of related projects are supported by GTZ, SIDA, USAID, FAO, and the World Bank.

SOUTH AFRICA

South Africa - Physical

Vegetation Types

According to White, the dominant vegetation types in South Africa include:

- Cape Shrubland

- Bush-Karoo Namib shrubland

- Dwarf Karoo Shrubland

- Transition from Karoo Shrubland to Highveld

The FRA 2000 shows tropical dry forest and tropical shrubland present in the north and especially the north east of the country.

${ }^{49}$ From: Corbett, A and Jones, B T B (2000) op cit 
Forest Cover Change: The FAO estimate for the change in forest cover between 1990 and 2000 is $-0.0 \%$ per annum. This has been calculated including the statistics on afforestation. The UN data used for the FRA 2000 shows a deforestation rate of 15000 ha in 1985, 18000 ha in 1990 and 20000 ha in 1996 . The main causes of this deforestation have been identified by the Ministry of Water Affairs and Forest as apartheid resettlements, conversion to agriculture and fuelwood harvesting.

Important legislation/institutional background: 1997 - National Forestry Action Programme. 1998 - National Forest Act.

Department of Water Affairs and Forestry has assumed responsibility for the sustainability of woodlands as a distinct resource. It is seen to be taking this role seriously, and is currently involved in:

- Evaluating the status of the resources and its benefits (both direct and indirect)

- Identifying threats to and enabling conditions for SFM

- Developing C\&I to assess whether the principles are being achieved

- developing management partnerships between communities on communal lands and private landowners.

- bush encroachment of major tracts of land, especially in the privately owned areas of savanna woodlands (INCO-DC project on Savannas ${ }^{50}$ )

TANZANIA

Tanzania - Physical

Vegetation Types

According to White, the dominant vegetation types in Tanzania are:

- South Zambezian Woodland

- Colophospermum mopane woodland and scrub woodland

The FRA 2000 shows tropical dry forest and tropical shrubland covering approximately two thirds of the country. The miombo woodlands extend from sea level to $1,600 \mathrm{~m}$ with an annual rainfall of $500-1,200 \mathrm{~mm}$ and one rainy season. Occupying the central plateau in the north and southeast, they are separated by a 'miombo-free' corridor about $500 \mathrm{~km}$ long and $60-120 \mathrm{~km}$ wide.

Forest Cover Change: The FAO estimate for the change in forest cover between 1990 and 2000 is $-0.2 \%$ per annum.

A case study from Tanzania demonstrates positive experiences of community management. The forest of Duru-Haitemba had been traditionally managed through a

${ }^{50}$ INCO-DC Annual Report (1999) op cit 
range of social-environmental rules. This system broke down when in 1992 the government attempted to demarcate the area as a forest reserve - local villagers wanted to 'remove what they could as fast as possible' and so transformed the forest area through extraction for charcoal and timber. A village by village system was then initiated whereby each village developed a practical management plan for conserving their part of the forest, leading eventually to the issue of Village Title Deeds.

Since the report in 1996, most of the countries in the region have developed new laws and polices relating to Forest management and land tenure, many of which incorporate community involvement and decentralisation. The status of these laws varies from country to country but Tanzania is highlighted as having made substantial progress towards democratising forest management ${ }^{51}$. Tanzania developed a National Forestry Policy in 1998 and at the time of writing was developing a draft Bill for a Forest Act which states as one of the underlying principles 'the delegation of responsibility for the management of forest resources to the lowest possible level'including both district and village councils (which is unique to Tanzania).

Tanzania has also incorporated Village Land Reserves into the Bill where land can be owned by villagers in common and registered as common hold. Village and Community Forests will be autonomously managed.

\section{ZAMBIA}

Over 55\% of Zambia's land area is covered by forest consisting of Brachystegia, Isoberlinia and Julbernardia. There is no particular institution responsible for all non-wood forest products, but there are 4 government departments with overall responsibility for national forests and wildlife: The Forest Department, Natural Resources Department, Fisheries Department, and the Department of Wildlife.

Constraints in terms of promoting and further developing NWFP included lack of information on NWFP in Zambia, manpower shortages, inadequate funding, and underdeveloped marketing structures.

Important Laws relating to forestry in Zambia include the National Forestry Policy (1998) and the Forests Act (1999). In these laws a clear distinction is made between local and national forests - community involvement is only allowed in local forests ${ }^{52}$. Whilst in theory local communities are 'owners' of local forests, the lack of easy

\footnotetext{
${ }^{51}$ Alden Wily, L (2000) The democratisation of forest management in eastern and southern Africa. International Forestry Review 2(4) pp 287 - 294

52 Alden Wily (2000) op cit
} 
routes in land tenure, local government and the forest law (through which they may form the required legal entity) is likely to hamper the practical implementation of the ownership.

Questions have been raised regarding the success rate of projects with a 'product centred focus'; in Zambia, they have included the demise of the Muzama initiative in NW Zambia where initial harvesting projects (both timber and NTFPs - honey etc) brought considerable benefit to local communities. The Forest Department then decided to refuse to renew the extraction licences - handing over the woodlands to more lucrative commercial concerns in 1999. The suggestion is that this is partly due to a weak relationship between the user groups and the Forest Department.

\section{Zambia - Physical}

The classification by White identified two main vegetation types:

- Wetter Zambezian miombo

- Drier Zambezian miombo

According to the FRA (FAO 2000) 'Tropical Dry Forest' covers approximately $1 / 3$ of the country. Woodland ecosystems within the country have been identified within four main types:

- Miombo - dominance of species of Brachystegia, Isoberlinia, Julbernardia and Marquesia. The woodland is present on the main plateau, from Kabwe towards Isoka in the northeast. It is also present on the southern plateau around Choma and Kalomo, the Copperbelt region and west of this.

- Kalahari - Dominant species include Burkea spp., Combretum mechowianum, Erythrophleum africanum and several others. It is thought to be secondary woodland, derived from fire, cultivation and erosion.

- mopane - this woodland is found only in the Zambezi depression. Its failure to spread to the north is thought to be due to the acidic soils of the uplands of the central African plateau.

- Munga - this woodland is thought to have developed from grassland to shrub and tree savanna. Fires are thought to have restricted the species to the fire resistant ones found there today. Species include: Acacia, Afromosia, Combretum, Ficus, Pterocarpus and Terminalia.

Climate and Soils: There are three identifiable seasons - a warm wet season, a cool/dry season and a warm/dry season. The wet season runs from November to April with rainfall varying from $700 \mathrm{~mm}$ per annum in the south to $1400 \mathrm{~mm}$ per annum in the north.

Forest Cover Change: The estimate for rate of forest cover change between 1990 and 2000 is $-2.4 \%$ per annum. Research carried out in 1998 suggests that the rate in the areas of Copperbelt, Central and Luapula is $-3.8 \%$ per annum and is mainly due to shifting cultivation and charcoal production. 
ZIMBABWE

Zimbabwe - Physical:

Tropical dry forest covers almost the whole country

Forest Cover Change: The rate of change of forest cover is estimated at $-1.5 \%$ per annum between 1990 and 2000. The UNDP state encroaching desertification and land degradation as two principal environmental concerns in Zimbabwe.

The 1997 Forestry Commission report states that woodlands cover approximately $66 \%$ of Zimbabwe's total land area and that approximately 70,000 ha are cleared for cultivation annually. During the 1980s, less land was cleared as subsidised agricultural inputs and more extension support improved yields. However, with the removal of subsidies over the past decade and several years of drought, farmers have been forced to clear more extensively ${ }^{53}$.

A recent report on management of savanna resources summarised some of the key issues relating to the experiences in Zimbabwe ${ }^{54}$.

CAMPFIRE was introduced in the mid-1980s as an attempt to redress the inequitable access to natural resources. Although concentrating on wildlife management, the focus on local resource use has also helped to increase the appreciation for the need for, and the means of, managing woodland sustainably.

The Eucalyptus woodlot extension programme, also introduced in the 1980s, failed to impact on local woodland use/management. A number of reasons for this failure are given in the report, including insignificant area planted; prohibitive cost of establishing nurseries; unpopularity of Eucalyptus for fuel wood.

The 1990s saw an increase in claims for land ownership, grazing rights etc relating to a community's proximity to an area or to historical connection with the land. However, despite the introduction of 'joint management' arrangements, illegal collection of forest products, settlement, livestock grazing has also increased. The report indicates that in 1998 there were an estimated 20,000 households in forest reserves.

\footnotetext{
${ }^{53}$ From: Southern African Savannas: sustainable management of natural resources (soil, water, flora and fauna) - a synthesis study of human impacts and enhancement of economic and social benefits. INCO-DC Annual Report (1999) www.savannas.org.uk/inco/udw.htm

${ }^{54}$ INCO-DC Annual Report (1999) www.savannas.org.uk/inco/udw.htm
} 
The 1994 Land Tenure Commission report stated that 'radical changes in tenure and rural governance systems in both communal and commercial areas are much needed'. Recent evidence suggests that in addition to this, there must be in place support services and effective incentives for conservation to avoid widespread stripping of woodlands.

\section{Community Forestry/Woodland Management - experiences without devolution}

IIED recently published a report on community forest management in Zimbabwe ${ }^{55}$. This paper summarises the key points of a case study carried out in the Chihota and Seke Communal Area which illustrated that community forest and woodland management initiatives were occurring without formal devolution of authority to local levels.

The underlying policy framework in the country is seen to be confusing - with contradictions between different laws and a total of 12 major acts governing natural resource management. The tenure regime in communal areas is described as common property, although in practice, common resources are managed under state property rules.

The communities living in this communal area managed one exotic and one indigenous woodlot, the latter being under the control of 4 village heads. The exotic woodlot is eucalyptus and it is managed by the RDC. The rules of access and harvesting for this area are not clear, and the community feels that the RDC has not succeeded in controlling tree cutting by outsiders who have had made no management inputs. The authors suggest that protection and management would be more actively pursued if farmers had better rights over forest and woodland resources. The issue of exclusion of outsiders is related to the absences of devolution regarding planning, decision making and administration to the local level. Without it, communities cannot negotiate the right to benefits arising from resources under communal tenure. In the local communities studied, the absence of a process to enforce the rights of the residents over their resources has been solved by some through 'privatising' forest resources by fencing areas closest to their homes.

The report suggests that there needs to be a balance in devolution - between the local level systems to use and manage the resource and the state - to regulate and provide technical services. This reiterates comments by other authors that traditional institutions need strengthening in parallel with devolution/ decentralisation initiatives.

\footnotetext{
${ }^{55}$ Katerere, Y; Guveya, E and Muir, K (1999) Community forest management: Lessons from Zimbabwe. IIED Drylands Issue Paper No. 89
} 


\section{Annex 2.1: Framework of potential activities AND milestones in four focus areas}

This table documents the discussions had with various members of the proposed project team and gives indicative activities, and milestones for each of the four Topics. The list of activities is largely drawn from the Yaounde meeting (Annex 2.2; CIFOR, 2001), and includes a mixture of types of research and dissemination activities, including review, empirical research and policy processes. Different elements of the mix can be tackled by interns, postgraduates, senior researchers etc. There are too many activities for the size of programme envisaged, but we list them in this Annex so as to capture the discussions that we have had, and as a basket of possibilities in an adaptive research programme, the evolution of which will be determined by funding and other resources. A summary proposal describes the main thrusts that will be undertaken with the currently available funds, and a workplan will be prepared for each year of the project, giving more details on actual activities.

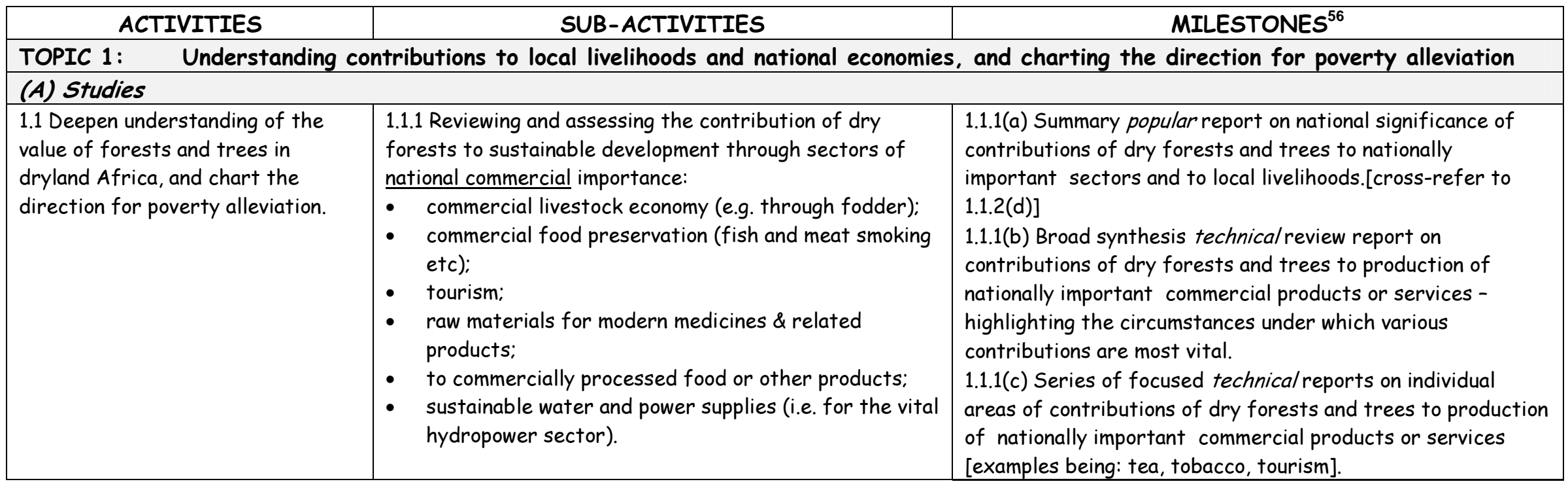

${ }^{56}$ Some of the technical reports may be university theses or documents that contribute to such theses. Scientific papers for refereed journals are assumed to be part of the milestones but are not explicitly recorded in this project document. "Publication" includes electronic variants as appropriate to the task. 


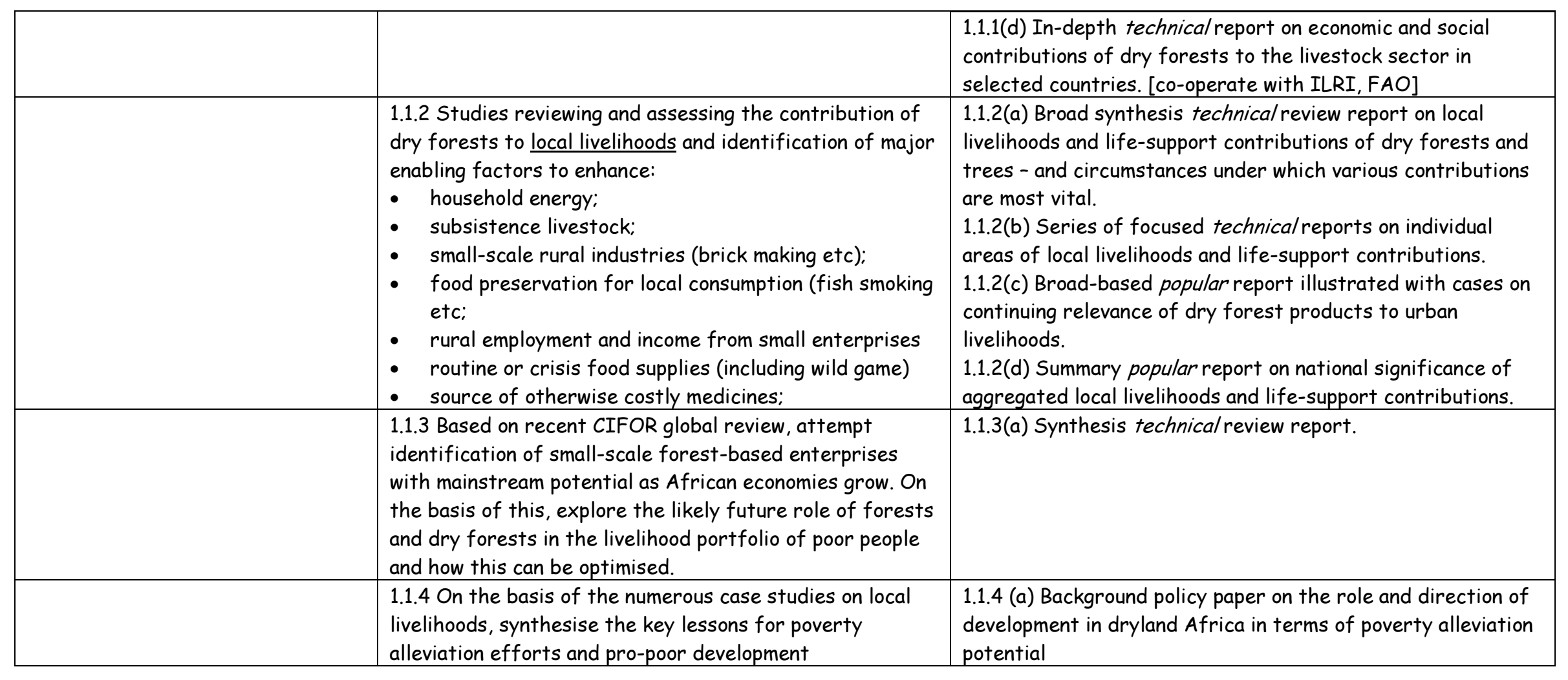


(B) Outreach/dissemination and capacity building

1.2 Convene a policy forum of

organisations promoting small-

business development, extension

officers, and NGOs to explore

income opportunities based on dry

forest and tree activities.

1.3 Bring findings of all studies

above for discussion and debate at

national level workshops.

1.4 Bring findings for discussion at

international level fora including

the Collaborative Partnership on

Forests (CPF), the CBD,

development banks, bilateral aid

agencies, and research institutions.

1.5 Train interns and host visiting

research fellows under exchange

programme of CIFOR.

1.2.1(a) Workshop report.

1.2.1(b) Policy brief

1.3.1(a) Workshop report.

1.3.1(b) Policy brief.

1.4.1(a) Policy briefs.

Trained or internationally exposed researchers from Africa. 
TOPIC 2 "The art of the possible" - tailoring sustainable management approaches for dry forests to the social, economic and technological capacities in Africa

\section{(A) Studies}

\subsection{Deepening the overall}

understanding of main factors supporting successful dry forest and tree resource management

(including policy, social and institutional factors). [with a view to identifying the most promising approaches and their enabling conditions for successful dry forest management].
2.1.1 Examine project experiences, existing studies and commission new research on successes and failures in dry forest management and their determinants.

2.1.2 Understanding elements of effective and sustained community participation in management of dry forests and trees. 2.1.1(a) Synthesis popular report on determinants of success and failure in dry forests management, illustrated by sample cases.

2.1.1(b) Technical review report of successes and failures in community-based forest management, identifying key determinants. From the review, select case studies for indepth examination leading to conceptual framework on factors conducive to success.

2.1.1(c) Technicalreview report successes and failures in government management of dry forests, identifying key determinants. From the review, select case studies for indepth examination leading to conceptual framework on factors conducive to success.

2.1.1 (d) Scientific review report on optimising the role of dry forests in land use in low-income environments [link to studies under 1.1 and 2.2.3].

2.1.2(a) Critical analytical technica/report "Community participation in management of Africa's dry forests: successes, myths, self-delusion and reality". 2.1.2(b) Synthesis technica/ review on the significance of differentiation in rural communities (rich, poor, temporary, permanent, male, female, nomadic pastoralists etc.) as a factor in successful management of local dry forest resources.

2.1.2(c) Synthesis technica/ review report on perception that regulatory burden on poor people is excessive; that forest laws have failed to adapt to decentralisation. 


\begin{tabular}{|c|c|c|}
\hline & & $\begin{array}{l}\text { 2.1.2(d) Conceptual technical document on prime needs for } \\
\text { harmonisation of conflicting and overlapping modern and } \\
\text { traditional rights, obligations and institutions applicable to } \\
\text { management of dry forests. } \\
\text { 2.1.2(e) Technica/review and synthesis of issues and } \\
\text { promising avenues in management of dry forests for wildlife } \\
\text { compatible with local community livelihoods. }\end{array}$ \\
\hline & & $\begin{array}{l}\text { 2.1.2(f) Review and case study based technicalreport on } \\
\text { local community perception of the value of biodiversity and } \\
\text { its link to species selection for traditional and modern } \\
\text { retention in rural landscapes. [Draw on ongoing ICRAF } \\
\text { research, including on tree domestication] } \\
\text { 2.1.2(g) Popular report on local community species } \\
\text { preferences in rural landscapes. }\end{array}$ \\
\hline \multirow[t]{2}{*}{$\begin{array}{l}2.2 \text { Critically evaluate silvicultural } \\
\text { practices to enhance sustainability } \\
\text { and value of forest goods and } \\
\text { services at all scales in low- } \\
\text { capacity environments. }\end{array}$} & $\begin{array}{l}\text { 2.2.1 Assemble, analyse and disseminate currently } \\
\text { dispersed knowledge on silvicultural options for managing } \\
\text { and rehabilitating dry forests for the main products and } \\
\text { services required. To be covered would be the } \\
\text { management options (including comparative cost \& } \\
\text { productivity performance) involved in: } \\
\text { - controlling access to or closing off natural vegetation to } \\
\text { allow regeneration; } \\
\text { - enrichment planting; } \\
\text { - plantations and woodlots; and } \\
\text { more intensive management of natural vegetation. }\end{array}$ & $\begin{array}{l}\text { 2.2.1(a) A technical synthesis publication on comparative } \\
\text { efficacy of the options including specific country cases. } \\
\text { 2.2.1(b) A popular publication on the top three technological } \\
\text { developments with most promise to improve dry forest } \\
\text { management in low-capacity countries and conditions for } \\
\text { their adoption. } \\
\text { 2.2.1(c) A series of popular publications/leaflets on } \\
\text { comparative efficacy of the options, including illustrative } \\
\text { country cases. } \\
\text { 2.2.1(d) Publicity materials on best practice on comparative } \\
\text { efficacy of the options including specific country cases. }\end{array}$ \\
\hline & $\begin{array}{l}\text { 2.2.2 The state of the art on technologies usable in low- } \\
\text { capacity environments for establishment, rehabilitation, } \\
\text { protection and utilisation of dry forests and their main } \\
\text { products. }\end{array}$ & $\begin{array}{l}\text { 2.2.2(a) An in-depth scientific publication on the top three } \\
\text { technological developments (same as in 2.1.1(b) with most } \\
\text { promise to improve dry forest management in low-capacity } \\
\text { countries and conditions for their adoption. }\end{array}$ \\
\hline
\end{tabular}




\begin{tabular}{|c|c|c|}
\hline & & $\begin{array}{l}\text { 2.2.2(b) Comparative technical analysis of performance and } \\
\text { costs of regrown natural dry forest versus plantations and } \\
\text { enrichment as basis for determining affordable resource } \\
\text { management technologies for local communities. } \\
\text { 2.2.2(c) Synthesis review technical document on the } \\
\text { significance of dry forest fallows and the state of the art } \\
\text { on their optimal management. }\end{array}$ \\
\hline & $\begin{array}{l}\text { 2.2.3 Understanding the key tree/crop/animal biophysical } \\
\text { interactions and dynamics in land use with proposals for } \\
\text { framework for optimising role of dry forests and trees. }\end{array}$ & $\begin{array}{l}\text { 2.2.3 (a) Broad overview technica/report on key } \\
\text { tree/crop/animal biophysical interactions and dynamics in } \\
\text { land use and changing roles of dry forests and trees in it. } \\
\text { 2.2.3 (b) Scientific review report on optimising place of dry } \\
\text { forests in land use in low-income environments [link to } \\
\text { studies under } 1.1 \text { and 2.2.3]. }\end{array}$ \\
\hline $\begin{array}{l}2.3 \text { Adapting application of } \\
\text { international criteria and indicators } \\
\text { (C\&I) of sustainable forest } \\
\text { management (SFM) to dry African } \\
\text { reality. }\end{array}$ & $\begin{array}{l}\text { 2.3.1 What absolutely essential core C\&I are needed to } \\
\text { achieve reasonable sustainability while avoiding dispersion } \\
\text { of effort over the extremely long international lists of } \\
\text { C\&I?. [in co-operation with FAO, UNEP] }\end{array}$ & $\begin{array}{l}\text { 2.3.1(a) A technica/review report with illustrative cases on } \\
\text { key criteria and indicators which, if satisfied, are enough to } \\
\text { nearly satisfy SFM and matching requirements to capacity. } \\
\text { 2.3.1(b) A popular everyman's guide to C\&I in dry forests. }\end{array}$ \\
\hline $\begin{array}{l}2.4 \text { Resource characterisation and } \\
\text { evaluation studies. [Information is } \\
\text { needed for prioritisation of } \\
\text { management and research effort]. }\end{array}$ & $\begin{array}{l}\text { 2.4.1 Review and synthesis of knowledge of the character } \\
\text { and extent of dry forests and comparative dependence of } \\
\text { people on them [link to studies 1.1.2; draw heavily on } \\
\text { recent FAO studies]. }\end{array}$ & $\begin{array}{l}\text { 2.4.1(a) Semi-popular presentation of latest situation and } \\
\text { implications for research and management effort priorities. }\end{array}$ \\
\hline
\end{tabular}




\begin{tabular}{|c|c|c|}
\hline \multicolumn{3}{|c|}{ (B) Outreach/dissemination and capacity building } \\
\hline $\begin{array}{l}2.5 \text { Organise specialised policy } \\
\text { forum of lawmakers and } \\
\text { administrators on appropriate } \\
\text { regulatory environment for } \\
\text { participatory dry forest and tree } \\
\text { management. }\end{array}$ & - & $\begin{array}{l}\text { 2.5.1(a) Workshop report. } \\
\text { 2.5.1(b) Popular leaflet "User friendly policy and law for } \\
\text { the forest-dependent poor" }\end{array}$ \\
\hline $\begin{array}{l}2.6 \text { Organise specialised forum of } \\
\text { officials and international partners } \\
\text { to discuss what } C \& I \text { burden is } \\
\text { realistic for Africa's dry forests. }\end{array}$ & - & 2.6.1(a) Workshop report. \\
\hline $\begin{array}{l}2.7 \text { To consider main findings of } \\
\text { studies under } 2.1 \text { - } 2.3 \text { inclusive, } \\
\text { convene a policy forum for donor } \\
\text { organisations, NGOs and senior } \\
\text { government officials to arrive at a } \\
\text { common understanding of the way } \\
\text { forward in managing dry forests } \\
\text { that suits Africa's capacity. }\end{array}$ & - & $\begin{array}{l}\text { 2.7.1(a) Workshop report. } \\
\text { 2.7.1(b) Popular leaflet "A manageable brand of dry forest } \\
\text { management in dry Africa" }\end{array}$ \\
\hline $\begin{array}{l}2.8 \text { Joint training courses for } \\
\text { government technical officers and } \\
\text { NGOs on factors leading to success } \\
\text { of community-based forestry } \\
\text { management (1 each in West and } \\
\text { Southern Africa). }\end{array}$ & - & 2.8.1(a) Compilation of training materials. \\
\hline $\begin{array}{l}\text { 2.9 Train interns and host visiting } \\
\text { research fellows under exchange } \\
\text { programme of CIFOR. }\end{array}$ & - & $\begin{array}{l}\text { 2.9.1(a) Trained or internationally exposed researchers } \\
\text { from Africa. }\end{array}$ \\
\hline
\end{tabular}




\begin{tabular}{|c|c|c|}
\hline ACTIVITIES & SUB-ACTIVITIES & MILESTONES \\
\hline \multicolumn{3}{|c|}{$\begin{array}{l}\text { TOPIC 3: Major trends - understanding key extra-sectoral determinants relevant to crafting policies and sustainable- } \\
\text { management approaches for dry forests. }\end{array}$} \\
\hline \multicolumn{3}{|c|}{ (A) Studies } \\
\hline \multirow[t]{4}{*}{$\begin{array}{l}\text { 3.1 Assemble, analyse and } \\
\text { disseminate information about } \\
\text { implications for dry forest cover of } \\
\text { developments in Africa's major } \\
\text { social and economic forces. }\end{array}$} & $\begin{array}{l}\text { 3.1.1 Broad review study (with sub-studies) to update } \\
\text { understanding of implications for dry forests of: } \\
\text { - } \quad \text { Population; } \\
\text { - Urbanisation; } \\
\text { - HIV/AIDS pandemic; } \\
\text { - Wars and refugees; } \\
\text { - Macroeconomic developments \& other economic } \\
\text { factors (intensification, diversification, changes in } \\
\text { - } \quad \text { Naverty, markets, urban-rural linkages, globalisation),; } \\
\text { - } \quad \text { Agricultural intensification }\end{array}$ & $\begin{array}{l}\text { 3.1.1(a) Semi-popular presentation of latest situation and } \\
\text { future prospects given projections of driving forces [FAO } \\
\text { and IFPRI projections]. } \\
\text { 3.1.1(b) In-depth technica/report on one or two most } \\
\text { important external underlying threats to dry forests. } \\
\text { 3.1.1(c) Popular report on one or two most important external } \\
\text { underlying threats to dry forests and possible responses. }\end{array}$ \\
\hline & $\begin{array}{l}\text { 3.1.2 In-depth forward-looking examination of trends and } \\
\text { scenarios in movement of the agricultural frontier and } \\
\text { implications for dry forests. Include driving forces for } \\
\text { agricultural expansion, such as local and international } \\
\text { demand. }\end{array}$ & $\begin{array}{l}\text { 3.1.2(a) In-depth technical analysis of latest situation and } \\
\text { future prospects given projections of driving forces for } \\
\text { agricultural expansion, both small-scale and commercial [FAO } \\
\text { and IFPRI projections]. } \\
\text { 3.1.2(b) Popular report on the farming frontier and dry } \\
\text { forests. }\end{array}$ \\
\hline & $\begin{array}{l}\text { 3.1.3 Study on tightening of land tenure and the } \\
\text { disappearance of forest available or accessible to local } \\
\text { people and their impacts on dry forests and the people } \\
\text { dependent on them. }\end{array}$ & $\begin{array}{l}\text { 3.1.3(a) Technical review/case studies compilation on state, } \\
\text { trends and driving forces for tenure evolution. }\end{array}$ \\
\hline & $\begin{array}{l}\text { 3.1.4 Donor policies favouring decentralisation and } \\
\text { devolution and their efficacy in promoting sustainable } \\
\text { management of dry forests and improved local livelihoods. }\end{array}$ & 3.1.4(a) Policy brief in glossy style for donor community. \\
\hline
\end{tabular}




\begin{tabular}{|c|c|c|}
\hline $\begin{array}{l}3.2 \text { Convene a visioning and } \\
\text { scenario-building forum with policy } \\
\text { makers at national and international } \\
\text { levels to explore alternative } \\
\text { development trajectories. }\end{array}$ & - & $\begin{array}{l}\text { 3.2.1 Reports of fora } \\
\text { 3.2.2 Policy briefs. }\end{array}$ \\
\hline $\begin{array}{l}\text { 3.3 Train interns and host visiting } \\
\text { research fellows under exchange } \\
\text { programme of CIFOR. }\end{array}$ & - & $\begin{array}{l}\text { 3.3.1 Trained or internationally exposed researchers from } \\
\text { Africa. }\end{array}$ \\
\hline
\end{tabular}




\begin{tabular}{|c|c|c|}
\hline ACTIVITIES & SUB-ACTIVITIES & MILESTONES \\
\hline \multicolumn{3}{|c|}{$\begin{array}{l}\text { TOPIC 4: Anticipating climate change - the Sahelian drought as Africa's "dry run" on socio-ecological resilience and adaptation ir } \\
\text { the dry forest zone. }\end{array}$} \\
\hline \multicolumn{3}{|c|}{ (A) Studies } \\
\hline \multirow{3}{*}{$\begin{array}{l}4.1 \text { Using the Sahelian droughts of } \\
\text { the } 1970 \text { s and } 1980 \text { s as well as } \\
\text { more recent climatic events, } \\
\text { derive lessons for future Climate } \\
\text { Change-giving attention to } \\
\text { technologies as well as policy and } \\
\text { socio-economic (including } \\
\text { institutional) adjustments. }\end{array}$} & $\begin{array}{l}\text { 4.1.1 Assess resilience of natural dry forests to drought: } \\
\text { focus on validating evidence of unexpectedly great } \\
\text { ecosystem resilience the anecdotally reported capacity of } \\
\text { natural dry forest and brush to recover productivity if } \\
\text { protected from grazing, fire, human harvest etc. }\end{array}$ & $\begin{array}{l}\text { 4.1.1(a) In-depth technical analysis of latest situation, } \\
\text { trends since the severe Sahelian drought, and future } \\
\text { prospects given expectations of future developments. }\end{array}$ \\
\hline & $\begin{array}{l}\text { 4.1.2 Performance of the most promising technologies } \\
\text { feasible for rural community management of dry forests in } \\
\text { the face of climate change. Known examples relate to: } \\
\text { seeding and cultivation methods; new crop varieties; and a } \\
\text { wide range of soil fertility conservation measures. }\end{array}$ & $\begin{array}{l}\text { 4.1.2(a) In-depth technicalanalysis of key technologies } \\
\text { feasible for rural communities to apply in responding to } \\
\text { progressive desiccation of the environment and other } \\
\text { changes. [Link with studies under } 2.2 .1 \text { - publication } \\
\text { 2.2.1(b)] } \\
\text { 4.1.2(b) Field guide on key technologies and how to promote } \\
\text { their adoption [link with study 4.1.3]. }\end{array}$ \\
\hline & $\begin{array}{l}\text { 4.1.3 Lessons of experience on rapid adaptation of farmers to } \\
\text { long term rainfall decline, drought and high demographic } \\
\text { growth in terms of their management of dry forests and on- } \\
\text { farm trees. Current indications suggest: (a) Greater } \\
\text { integration of land-use, (b) Intensified management and } \\
\text { privatisation of scarce resources (c) Changing role of dry } \\
\text { forests in rural livelihoods including shifts in the nature and } \\
\text { degree of dependence on them. }\end{array}$ & $\begin{array}{l}\text { 4.1.3(a) In-depth technica/review report on changing roles } \\
\text { of dry forests and trees in livelihoods during climate } \\
\text { change and presenting the state of the art on main coping } \\
\text { adjustments. } \\
\text { 4.1.3(b) Analytical technica/report on factors influencing } \\
\text { ease of farmer adaptation and presenting possible policy } \\
\text { incentives needed to improve adaptability of livelihoods and } \\
\text { resilience of ecosystems. } \\
\text { 4.1.3(c) Policy briefs. }\end{array}$ \\
\hline
\end{tabular}


(B) Outreach/dissemination and capacity building

\begin{tabular}{|c|c|c|}
\hline $\begin{array}{l}\text { 4.2 Establish links with CILSS, the } \\
\text { UNCCD, and UNEP to share } \\
\text { findings within Africa and with } \\
\text { climate change mechanisms within } \\
\text { the CGIAR and in the UNFCCC } \\
\text { process for international dialogue.. }\end{array}$ & - & - \\
\hline $\begin{array}{l}\text { 4.3 Train interns and host visiting } \\
\text { research fellows under exchange } \\
\text { programme of CIFOR. }\end{array}$ & - & $\begin{array}{l}\text { Trained or internationally exposed researchers from } \\
\text { Africa. }\end{array}$ \\
\hline
\end{tabular}





\section{Annex 2.2: Dry sub-regions' extract from Africa research prioritisation meeting}

$$
\text { (Yaounde, Cameroon }{ }^{57}-20-23 \text { February 2001) }
$$

At the Yaounde (Cameroon) meeting convened by CIFOR in February 2001 to identify research priorities in African forestry, participants arrived at the following headings, under which specific biophysical and socio-economic and policy research topics can be carried out:

- Facilitating the beneficial role of forests and trees in the landscape, including agriculture - forest interactions

- Development or refinement of techniques and practices for enhanced productivity, sustainability and livelihood relevance of dry forests and trees in the landscape (including techniques for complementing and rehabilitating degraded dry forests and use of forests and trees in rehabilitating degraded lands)

- Identifying and characterising the impacts of policies and external developments on forests

- Enhancing rural livelihoods through forest products

- Enabling socio-economic, policy and institutional environment for community-based forest management

- Capacity building and institutional support

The tables below reflect the above organisation; the possible research areas and issues in dry sub-Saharan Africa.

${ }^{57}$ CIFOR, 2001. Forestry research in Sub-Saharan Africa: priorities and potential niches for the Center for International Forestry Research (CIFOR). Report of the partners meeting on a strategy for the activities of CIFOR in Sub - Saharan Africa. CIFOR Regional Office for Humid Central and West Africa, 20 - 23 February 2001. Humid Forest Ecoregional Centre, IITA, Nkolbisson, Yaounde, Cameroon. 
1. The role of forests and trees in the landscape, including agriculture and forest interactions

(a) Managing competition 1.1 Eastern and Southern Africa58

between humans,

livestock, and wildlife in

What are the principal factors driving competition for miombo resources?

miombo woodlands.

What are the consequences of the competition on rural livelihoods, wildlife conservation, forest conditions, and other forms of land use?

What are the policy and institutional arrangement options to contain the competition?

(b) Role of Forests And Trees in the landscape.

How can forest and trees in the landscape be managed to enhance water catchment potential?

What is the potential of dry forests and trees on farms as carbon sinks and how can this potential benefit local communities?

How does the disturbance of natural forests affect human and wildlife habitats? What are the consequences of the competition on rural livelihoods, wildlife conservation, forest conditions, and other forms of land use?

(a) The changing patterns of pastoralism and its effects on dry forests

\subsection{Dry West Africa}

What are the impacts of changing patterns of sedenterisation of traditionally transhuman pastoral communities on dry forests in the land-use context and what responses hold most promise?

What continuing roles can be seen for dry forests in supporting pastoralism and how best can this contribution be designed into dry forest management regimes?

(b) Underlying causes of How can forest and trees in the landscape be managed to enhance water wildlife/people conflicts. catchment potential?

What is the potential of dry forests and trees on farms as carbon sinks and how can this potential benefit local communities?

How does the disturbance of natural forests affect human and wildlife habitats?

What are the consequences of the competition on rural livelihoods, wildlife conservation, forest conditions, and other forms of land use?

2. Impacts of policies and external developments on forests
(a) Rapid socio-economic
2.1 Eastern and Southern Africa

changes and their implications

How will [HIV/AIDS-induced]changes in age distribution, labour force, gender roles and attitudes relate to resource use and management?

(b) Trends in tobacco industry and impact on dry forest

(c) Impacts of policies and external What is the implication of potential shrinking of tobacco industry on the dry forest and rural livelihoods?

How do land-based sectoral and economic reform policies influence community management and use of trees and forests?

developments on forests

What is the nature of gaps in the policy dialogue continuum and how can they be bridged?

\subsection{Dry West Africa}

(a) Implications of external developments and policies on dry forest degradation and deforestation.

What are the implications for dry forests of changing agricultural technologies (including intensification), commodity market fluctuations, and changing urban demands for agricultural products?

What are the impacts of changing patterns of sedenterisation of traditionally transhuman pastoral communities on dry forests in the land-use context and what responses hold most promise?

What impacts on dry forests come from economic liberalisation and other

\footnotetext{
${ }^{58}$ The suggestions here refer mostly to the miombo and related woodland areas of the African plateau.
} 
(b) Underlying causes of bushfires

(c) Impacts of unpredictability of climate and of climate change on dry forest and implications for livelihoods

(e) Impacts of riverblindness and tsetse fly eradication on dry land vegetation, wildlife and livelihoods based on them macroeconomic reforms? [extension to dryland Africa of earlier global CIFOR studies and miombo woodland studies in Eastern/Southern Africa]

What are the social (including cultural) and economic factors leading to dry West Africa's high incidence of bush fires and what technological/social approaches can most effectively combat them and their negative livelihood impacts?

Given the perception that many bush-fires relate to demands for fresh pasture, what dry forest-compatible land management options can meet the livestock sector's needs?

How important are long-established climate unpredictability and more recent climate change concerns affecting dry forests/dry forest-based livelihoods and what response options hold promise?

What is the scale of dry forests affected by river-blindness and tsetse fly and what could be effects on the dry forests of (a) applying available eradication technologies or coping mechanisms (e.g. use of trypano-tolerant breeds), (b) increased human and livestock settlement following eradication of the diseases?.

3. Enhancing rural livelihoods through forest products

(a) Enterprise development at the local community level using trees and forest resources

(a) Dry forest contribution to diversification of opportunities and enterprise development for the rural poor

4. Governance and institutional arrangements for community-based forest management

(a) Governance and institutional arrangements for community based forest management 4.1 Eastern \& Southern Africa

\subsection{Eastern and Southern Africa}

What are the potential opportunities for enhancing the value of dry forests in rural livelihoods?

How this potential can be realised (strategies for rural enterprises development)?

\subsection{Dry West Africa}

How do land-based sectoral and economic reform policies influence community management and use of trees and forests?

What is the nature of gaps in the policy dialogue continuum and how can they be bridged?

What are roles and capacities of rural communities to sustainably manage the dry forests in rapidly evolving socio-economic environment? 


\begin{tabular}{|c|c|}
\hline $\begin{array}{l}\text { (a) Criteria and } \\
\text { Indicators based } \\
\text { adaptive sustainable } \\
\text { management of dry } \\
\text { forests (extension of } \\
\text { global CIFOR work) } \\
\text { (b) Traditional knowledge } \\
\text { and intellectual property } \\
\text { rights mechanisms for } \\
\text { forest management and } \\
\text { use } \\
\text { (c) Adaptation of } \\
\text { resources management } \\
\text { regimes to evolving } \\
\text { traditions and social, } \\
\text { cultural, institutional and } \\
\text { economic changes in the } \\
\text { Sahel }\end{array}$ & $\begin{array}{l}\text { D.2 Dry West Africa } \\
\text { What minimum of core criteria and indicators that local people can cope with } \\
\text { implementing would achieve a desirable level of sustainable resource } \\
\text { management? } \\
\text { Traditional knowledge of the dry forests, their use and management is fast } \\
\text { eroding. What are the most critical areas of knowledge to prioritise for } \\
\text { recording and conservation and what are possible approaches to integrating } \\
\text { with modern scientific knowledge? [could choose to break down by function e.g. } \\
\text { medicinals, food uses, construction materials etc] } \\
\text { What are the key changes in rural society and outside it and how do they } \\
\text { affect dry forests management [macro-issue with micro-illustrations]? } \\
\text { What adaptations to traditional approaches to management can cope with the } \\
\text { changing society? }\end{array}$ \\
\hline
\end{tabular}


Annex 2.3: Africa - selected forest resource and conservation indicators

\begin{tabular}{|c|c|c|c|c|c|c|c|c|c|c|c|}
\hline & \multicolumn{3}{|c|}{$\begin{array}{l}\text { FOREST RESOURCE YEAR } \\
2000\end{array}$} & \multirow{2}{*}{$\begin{array}{l}\text { FOREST } \\
\text { LOSS RATE } \\
\text { \% per year/ } \\
\text { Population } \\
\text { growth \% } \\
\text { per year }\end{array}$} & \multicolumn{2}{|c|}{$\begin{array}{c}\text { FOREST } \\
\text { MANAGEMENT }\end{array}$} & \multicolumn{5}{|c|}{$\begin{array}{c}\text { RATIFIED INTERNATIONAL ENVIRONMENTAL } \\
\text { CONVENTIONS }\end{array}$} \\
\hline & $\begin{array}{l}\% \text { of all } \\
\text { land }\end{array}$ & $\begin{array}{l}\mathrm{Ha} \\
\text { /capita }\end{array}$ & $\begin{array}{l}\text { Biomass } \\
\text { tons /ha }\end{array}$ & & $\begin{array}{c}\% \\
\text { forest } \\
\text { with } \\
\text { manage } \\
\text { ment } \\
\text { plans }\end{array}$ & $\begin{array}{c}\% \text { forest } \\
\text { in } \\
\text { protecte } \\
\text { d areas }\end{array}$ & $\begin{array}{c}\text { UN } \\
\text { Biologica } \\
\text { I } \\
\text { Diversity }\end{array}$ & $\begin{array}{c}\text { UN } \\
\text { Climate } \\
\text { Change }\end{array}$ & $\begin{array}{c}\text { UN } \\
\text { Desertifica } \\
\text { tion }\end{array}$ & CITES & $\begin{array}{c}\text { Ramsar } \\
\text { (Wetlands } \\
\text { ) }\end{array}$ \\
\hline \multicolumn{12}{|c|}{ FRANCOPHONE DRY WEST AFRICA } \\
\hline & & & & & & & & & & & \\
\hline B. Faso & 25.9 & 0.6 & 16 & $-0.2 / 2.8$ & 9.8 & 11 & $x$ & $x$ & $x$ & $x$ & \\
\hline Camer'n* & 51.3 & 1.6 & 131 & $-0.9 / 2.7$ & - & 11 & $x$ & $x$ & $x$ & & $x$ \\
\hline C. Verde & 21.1 & 0.2 & 127 & $9.3 / 2.4$ & - & - & $x$ & $x$ & $x$ & & \\
\hline Chad & 10.1 & 1.7 & 16 & $-0.6 / 2.7$ & - & 27 & $x$ & $x$ & $x$ & $x$ & \\
\hline C. d'Iv're* & 22.4 & 0.5 & 130 & $3.1 / 1.8$ & 19.5 & 10 & $x$ & $x$ & $x$ & $x$ & $x$ \\
\hline Gambia & 48.1 & 0.4 & 22 & $1.0 / 2.6$ & - & 3 & $x$ & $x$ & $x$ & $x$ & $x$ \\
\hline G. Bissau & 28.2 & 0.9 & 114 & $-0.9 / 2.2$ & - & 1 & $x$ & $x$ & $x$ & $x$ & $x$ \\
\hline Mali & 10.8 & 1.2 & 31 & $-0.7 / 2.5$ & - & 7 & $x$ & $x$ & $x$ & $x$ & $x$ \\
\hline Niger & 1.0 & 0.1 & 4 & $-3.7 / 3.2$ & - & 77 & $x$ & $x$ & $x$ & $x$ & $x$ \\
\hline Senegal & 32.2 & 0.7 & 30 & $-0.7 / 2.6$ & - & 16 & $x$ & $x$ & $x$ & $x$ & $x$ \\
\hline
\end{tabular}




\begin{tabular}{|c|c|c|c|c|c|c|c|c|c|c|c|}
\hline & \multicolumn{3}{|c|}{$\begin{array}{l}\text { FOREST RESOURCE YEAR } \\
2000\end{array}$} & \multirow{2}{*}{$\begin{array}{c}\text { FOREST } \\
\text { LOSS RATE } \\
\% \text { per year } \\
/ \\
\text { Population } \\
\text { growth \% per } \\
\text { year }\end{array}$} & \multicolumn{2}{|c|}{$\begin{array}{c}\text { FOREST } \\
\text { MANAGEMENT }\end{array}$} & \multicolumn{5}{|c|}{$\begin{array}{c}\text { RATIFIED INTERNATIONAL ENVIRONMENTAL } \\
\text { CONVENTIONS }\end{array}$} \\
\hline & $\begin{array}{l}\% \text { of all } \\
\text { land }\end{array}$ & $\begin{array}{l}\text { Ha } \\
\text { /capita }\end{array}$ & $\begin{array}{l}\text { Biomass } \\
\text { tons/ha }\end{array}$ & & $\begin{array}{c}\% \\
\text { forest } \\
\text { with } \\
\text { manage } \\
\text { ment } \\
\text { plans }\end{array}$ & $\begin{array}{l}\% \text { forest } \\
\text { in } \\
\text { protected } \\
\text { areas }\end{array}$ & $\begin{array}{c}\text { UN } \\
\text { Biological } \\
\text { Diversity }\end{array}$ & $\begin{array}{c}\text { UN } \\
\text { Climate } \\
\text { Change }\end{array}$ & $\begin{array}{c}\text { UN } \\
\text { Desertifica } \\
\text { tion }\end{array}$ & CITES & $\begin{array}{c}\text { Ramsar } \\
\text { (Wetlands } \\
\text { ) }\end{array}$ \\
\hline \multicolumn{12}{|c|}{ DRYLAND ANGLOPHONE AFRICA NORTH OF THE EQUATOR } \\
\hline Ghana* & 27.8 & 0.3 & 88 & $-1.7 / 2.7$ & - & 9 & $\mathrm{X}$ & $x$ & $x$ & $x$ & $\mathrm{X}$ \\
\hline Kenya & 30.0 & 0.6 & 48 & $-0.5 / 2.0$ & - & 40 & $\mathrm{X}$ & $x$ & $x$ & $x$ & $\mathrm{X}$ \\
\hline Nigeria* & 14.8 & 0.1 & 184 & $-2.6 / 2.4$ & - & 7 & $x$ & $x$ & $x$ & $x$ & \\
\hline Sudan* & 25.9 & 2.1 & 12 & $-1.4 / 2.1$ & - & 7 & $x$ & $x$ & $x$ & $x$ & \\
\hline \multicolumn{12}{|c|}{ DRY FORESTS IN SOUTHERN AFRICA } \\
\hline Angola & 56.0 & 5.6 & 75 & $-0.2 / 3.3$ & - & 3 & $\mathrm{X}$ & $x$ & $\mathrm{X}$ & & \\
\hline Botswana & 21.9 & 7.8 & 63 & $-0.9 / 1.9$ & - & 26 & $x$ & $x$ & $x$ & $x$ & $x$ \\
\hline Malawi & 27.2 & 0.2 & 143 & $-2.4 / 2.5$ & - & 45 & $x$ & $x$ & $x$ & $x$ & $x$ \\
\hline Moz'bque & 39.0 & 1.6 & 41 & $-0.2 / 2.5$ & - & 7 & $x$ & $x$ & $x$ & $x$ & \\
\hline Namibia & 9.8 & 4.7 & 12 & $-0.9 / 2.3$ & - & 5 & $x$ & $x$ & $x$ & $x$ & $x$ \\
\hline S. Africa & 7.3 & 0.2 & 81 & $-0.1 / 1.5$ & - & 7 & $x$ & $x$ & $x$ & $x$ & $x$ \\
\hline Tanzania & 43.9 & 1.2 & 60 & $-0.2 / 2.3$ & - & 14 & $x$ & $x$ & $x$ & $x$ & $x$ \\
\hline Zambia & 42.0 & 3.5 & 104 & $-2.4 / 2.3$ & - & 24 & $x$ & $x$ & $x$ & $x$ & $x$ \\
\hline Zimbabwe & 49.2 & 1.7 & 56 & $-1.5 / 1.4$ & - & 12 & $x$ & $x$ & $x$ & $x$ & \\
\hline
\end{tabular}

* = countries with significant areas of rainforest within their borders.

Source: FAO - State of the World's Forests 2001. Annex 2, Tables 2 - 4 


\section{Annex 3.1: Stakeholder groups that will be engaged in the dry forest Programme}

1. Poor people themselves. This group constitutes both the primary beneficiaries and the clients of the research. While CIFOR recognizes that it does not have a comparative advantage to extend such research results broadly, we will develop research collaborations with partners that have the capacity and the mandate to communicate and apply the research findings in development and conservation initiatives. Research results will be packaged and made available to the advocates of the poor (e.g. NGOs, cooperatives), as inputs to their resource planning and management.

2. Donor and development agencies, including government agencies, national and international non-governmental agencies, and international aid agencies. Natural resource based development as a strategy to improve livelihoods or to achieve sustainable management has a relatively high priority on the agendas of development agencies. The Dry Forest programme focuses specifically on providing analyses and information to assist with priority setting and with the design of appropriate interventions by development projects.

3. National and regional policy makers. Some of the key outputs from the Programme's research will be analyses of the impacts of policy on dry forests and livelihoods. Interaction will be sought in national and regional forums, where researchers are able to take part in processes leading to policy reform. Two classes of policy makers will be recognized; those with in the forest (or natural resource) sector and those outside the sector (finance ministries, agricultural ministries etc.) 